

ROYAL ONTARIO MUSEUM

LIFE SCIENCES CONTRIBUTIONS

162

\section{SYSTEMATIC ICHNOLOGY OF THE}

LATE ORDOVICIAN GEORGIAN BAY FORMATION OF SOUTHERN ONTARIO, EASTERN CANADA

D. Christopher A. Stanley and Ron K. Pickerill

\section{$\mathrm{RO̊̊M}$}

ROYAL ONTARIO MUSEUM 
All rights reserved. No part of this publication may be reproduced, stored in a retrieval system or data base, or transmitted, in any form or by any means, electronic, mechanical, photocopying, or otherwise, without the prior written consent of the publisher.

First published in 1998 by the Royal Ontario Museum, 100 Queen's Park, Toronto, Ontario M5S 2 C6.

Publication date: 30 Junc 1998

\section{Canadian Cataloguing-in-Publication Data}

Stanley, D. Christopher A.

Systematic ichnology of the Late Ordovician Georgian Bay Formation of Southern Ontario, eastern Canada

(Life sciences contributions, ISSN 0384-8159; 162) Includes bibliographical references.

ISBN 0-88854-423-5

1. Ichnology - Ontario, Southern. 2. Trace fossils Ontario, Southern. 2. Paleontology - Ontario, Southern Ordovician. I. Pickerill, R. K. II. Royal Ontario Museum. III. Title. IV. Series.

\section{QE720.5.S83 $1998 \quad 560^{\prime} .9713 \quad$ C97-931841-6}

\section{ROYAL ONTARIO MUSEUM PUBLICATIONS IN LIFE SCIENCES}

The Royal Ontario Museum publishes books on a variety of subjects in the life sciences, including Life Sciences Contributions, a numbered series of original scientific publications. All manuscripts considered for publication are subject to the scrutiny and editorial policies of the Academic Editorial Board, and to independent refereeing by two or more persons, other than Museum staff, who are authorities in the particular field involved.

\section{ACADEMIC EDITORIAL BOARD}

Chair: Chris McGowan

Members (Science): D. H. Collins, T. A. Dickinson, R. D. James

Members (Art \& Archaeology): L. Golombek, P. Kaellgren, P. L. Storck

Manuscript Editor: R. D. James

Production Editor: Andrea Gallagher Ellis

D. Christopher A. Stanley works in the Vancouver office of the Geological Survey of Canada, 101-605 Robson Street, Vancouver, British Columbia V6B 5J3.

Ron K. Pickerill is a professor in the Department of Geology, University of New Brunswick, P. O. Box 4400, Fredericton, New Brunswick E3B 5A3.

Cover: Rusophycus polonicus Orlowski, Radwański and Roniewicz, convex hyporelief, ROM 49429.

The Royal Ontario Museum is an agency of the Ontario Ministry of Citizenship, Culture and Recreation.

Printed and bound in Canada 


\section{Contents}

Abstract 1

Introduction 2

Purpose 2

Study Area 2

Previous Work-Sedimentology/Stratigraphy 2

Previous Work-Ichnology 2

Ichnofacies 2

Systematic Ichnology 5

Introductory Remarks 5

Ichnogenus Arenituba Stanley and Pickerill, 19955

Ichnogenus Arthraria Billings, 18726

Ichnogenus Aulichnites Fenton and Fenton, 19376

Ichnogenus Chondrites von Sternberg, 18337

Ichnogenus Cochlichnus Hitchcock, $1858 \quad 8$

Ichnogenus Cruziana d'Orbigny, 184210

Ichnogenus Curvolithus Fritsch, 190812

Ichnogenus Didymaulichnus Young, 197212

Ichnogenus Diplocraterion Torell, 187013

Ichnogenus Fustiglyphus Vialov, 197115

Ichnogenus Gordia Emmons, 184415

Ichnogenus Gyrochorte Heer, 186516

Ichnogenus Helminthopsis Heer, 187716

Ichnogenus Lingulichnus Hakes, 197617

Ichnogenus Monocraterion Torell, 187018

Ichnogenus Monomorphichnus Crimes, 197019

Ichnogenus Paleodictyon Meneghini in Murchison, 185020

Ichnogenus Palaeophycus Hall, 184720

Ichnogenus Phycodes Richter, 185022

Ichnogenus Planolites Nicholson, 187323

Ichnogenus Protovirgularia McCoy, 185024

Ichnogenus Rusophycus Hall, 185225

Ichnogenus Skolithos Haldeman, 184027

Ichnogenus Trichophycus Miller and Dyer, 187828

Concluding Remarks 30

Acknowledgements 31

Literature Cited 32

Appendix 1: ROM Repository Numbers 40

Appendix 2: Locality Details-Toronto Region 41

Appendix 3: Comparison of Ichnotaxa from the Cincinnatian of Ohio and the Georgian Bay Formation 42

Plates 43 
Digitized by the Internet Archive in 2011 with funding from Royal Ontario Museum 


\title{
Systematic Ichnology of the Late Ordovician Georgian Bay Formation of Southern Ontario, Eastern Canada
}

\begin{abstract}
The Late Ordovician Georgian Bay Formation of southern Ontario comprises between 127 and $177 \mathrm{~m}$ of alternating predominantly grey shales and grey calcareous sandstones, and is informally subdivided into lower shale-dominated and upper sandstone-dominated members. The succession is interpreted as a storm-dominated shelf sequence; many individual sandstone-shale couplets display all or part of a characteristic internal sequence encompassing a basal lag zone overlain by hummocky cross-stratification overlain by horizontal-laminated and cross-laminated deposits, all overlain by shale.

While the upper member, as exposed extensively on Manitoulin Island, contains few and only poorly preserved trace fossils, the lower member has revealed an abundant ichnofauna characterized by 26 ichnogenera represented by at least 47 ichnospecies, namely, Arenicolites isp.; Arenituba verso (Chamberlain, 1971a); Arthraria antiquata Billings, 1872; Aulichnites parkerensis Fenton and Fenton, 1937; Chondrites isp.; Cochlichnus anguineus Hitchcock, 1858; Cochlichnus n. isp.; Cruziana cf. lobosa Seilacher, 1970; Cruziana problematica (Schindewolf, 1921); Cruziana quadrata Seilacher, 1970; Cruziana ispp.; Curvolithus multiplex Fritsch, 1908; Didymaulichnus lyelli (Rouault, 1850); Diplocraterion cf. biclavatum (Miller, 1875); Diplocraterion helmerseni (Öpik, 1929); Diplocraterion parallelum Torell, 1870; Fustiglyphus annulatus Vialov, 1971; Gordia marina Emmons, 1844; Gyrochorte comosa Heer, 1865; Helminthopsis hieroglyphica Wetzel and Bromley, 1996; cf. Lingulichnus verticalis Hakes, 1976; Lockeia siliquaria James, 1879; cf. Monocraterion tentaculatum Torell, 1870; Monomorphichnus bilinearis Crimes, 1970; Monomorphichnus lineatus Crimes, Legg, Marcos and Arboleya, 1977; cf. Palaeophycus crenulatus Buckman, 1995; Palaeophycus heberti (de Saporta, 1872); Palaeophycus striatus Hall, 1852; Palaeophycus tubularis Hall, 1847; Paleodictyon ispp. a-b; Phycodes flabellus (Miller and Dyer, 1878a); Phycodes palmatus (Hall, 1852); Planolites annularius Walcott, 1890; Planolites beverleyensis (Billings, 1862); Planolites constriannulatus Stanley and Pickerill, 1994; Protovirgularia rugosa (Miller and Dyer, 1878a); ?Protovirgularia isp.; Rusophycus carbonarius Dawson, 1864; Rusophycus cryptolithi Osgood, 1970; Rusophycus osgoodii n. isp.; Rusophycus polonicus Orlowski, Radwański and Roniewicz, 1970; Rusophycus pudicus Hall, 1852; Skolithos magnus Howell, 1944; Skolithos verticalis (Hall, 1843); Trichophycus lanosus Miller and Dyer, 1878a; and Trichophycus venosus Miller, 1879.

This association of ichnotaxa contains elements of the Cruziana ichnofacies, indicative of a subtidal environment below fair-weather wave base, but above storm wave base. In overall taxonomic composition the ichnofaunal assemblage compares favourably to that from coeval and palacoenvironmentally similar strata previously documented from carbonates of the Cincinnatian Series of Ohio.
\end{abstract}




\section{Introduction}

\section{PURPOSE}

The Late Ordovician Georgian Bay Formation of southern Ontario represents a storm-deposited sequence, 127-177 $\mathrm{m}$ thick, predominantly comprising interbedded grey shalcs and grey calcareous sandstones (Kerr and Eyles, 1991). It contains a diverse ichnofauna that can be assigned to the Cruziana ichnofacies of Seilacher (1964, 1967). Virually no systematic ichnological research has been undertaken in this formation since Fritz $(1925,1926)$ described several "fucoids" from these strata. The principal purpose of this study, therefore, is to re-assess taxonomically all previously collected material, supplemented by new and additional collections made by us between 1990 and 1992, thereby providing an updated catalogue of the ichnology of the formation for possible future comparative purposes.

\section{STUDY AREA}

The Georgian Bay Formation of southern Ontario, eastern Canada, crops out along a northwesterly-southeasterly trending belt from the shores of Lake Ontario at Toronto and Mississauga in the southeast, through the shores of Georgian Bay at Meaford, and onto the northern shores of Manitoulin Island in the northwest (Text-Fig. 1). Surface outcrop of the formation is restricted to the Toronto/ Mississauga and Meaford areas, where numerous riverbank and creek sections exist, and to various localities on Manitoulin Island, where road-cut, riverbank, and waterfall sections are present. Most of the area between Toronto and the shores of Georgian Bay is covered by extensive glacial drift, resulting in only very rare exposures along small inland creeks. Access to sections in the Toronto/ Mississauga area is granted by bicycle paths along the banks of the Credit, Don, and Humber rivers, as well as along Mimico and Etobicoke creeks (Text-Fig. 2). In the Georgian Bay area, the type locality of the Georgian Bay Formation, along the banks of Workman's Creek, is accessible where it is crossed by Highway 26. Additional sections in the area are present on sideroads. Sections on Manitoulin Island are easily visited by the numerous paved and gravel roads covering the island.

\section{PREVIOUS WORK- SEDIMENTOLOGY/STRATIGRAPHY}

Historically, most geological research on the Georgian Bay Formation has been in the arcas of sedimentology, macropalacontology, biostratigraphy, and, more recently, lithostratigraphy (Focrste, 1912, 1916, 1924; Fritz, 1925, 1926, 1946, 1951, 1970, 1971; Parks, 1925, 1928; Caley, 1936, 1940; Okulitch, 1939; Gorrell, 1952; Liberty, 1953,
1969; Sanford, 1961; Beards, 1967; Lajtai, 1969; Liberty and Bolton, 1971; Winder and Sanford, 1972; Burke et al., 1973; Haugh, 1979; Kobluk, 1980; Russell and Telford, 1983; Eckert, 1987). In addition to these studies, Burke et al. (1973) and particularly Kerr and Eyles (1991) outlined palacoenvironmental interpretations for the formation, and descriptions of the sedimentology are also available in several fieldtrip guidebooks (Liberty, 1954, 1964, 1968, 1978; Sanford and Mosher, 1978). The geology of the formation, as it appears on Manitoulin Island, has more recently received attention from Byerley and Coniglio (1989a, 1989b, 1991).

\section{PREVIOUS WORK-ICHNOLOGY}

To date, no comprehensive ichnological study of the Georgian Bay Formation has been undertaken. Several specimens described by Fritz $(1925,1926)$ as plant fossils, or "fucoids," were in fact trace fossils, while Burke et al. (1973), Byerley and Coniglio (1989a), and Kerr and Eyles (1991) offered partial, but not totally correct, ichnotaxonomic lists of traces present in the formation. The relatively diverse and generally well preserved ichnofauna of this formation is the focus of this study.

\section{ICHNOFACIES}

The ichnofacies concept was originally introduced by Seilacher $(1964,1967)$ in order to illustrate the association of recurrent trace-fossil assemblages with palaeoenvironmental conditions. While Seilacher's original concept of archetypal ichnofacies as a series of depth-dependent assemblages was truly visionary in the sixties and can still be applied in many situations, it is now recognized that changes in other environmental parameters associated with increasing water depth, such as salinity, temperature, oxygen, and current strength, are crucial to the makeup of a recurring ichnocoenose (Frey et al., 1990; Bromley, 1990). Trace fossils from the Georgian Bay Formation can collectively be referred to the Cruziana ichnofacies (cf. Rudkin, 1981; Kerr and Eyles, 1991). This ichnofacies possesses abundant crawling traces, inclined or vertical Ushaped burrows displaying mostly protrusive spreite, and scattered vertical cylindrical burrows, and is characterized by a generally high diversity and abundance (Frey and Pemberton, 1984). An environment characterized by subtidal, unconsolidated substrates associated with either modcrate energy levels in shallow waters (below daily wave base but above storm wave base) or reduced energy levels in deeper, quieter waters is generally indicative of this ichnofacies (Frey and Pemberton, 1984; Frey et al., 1990). 


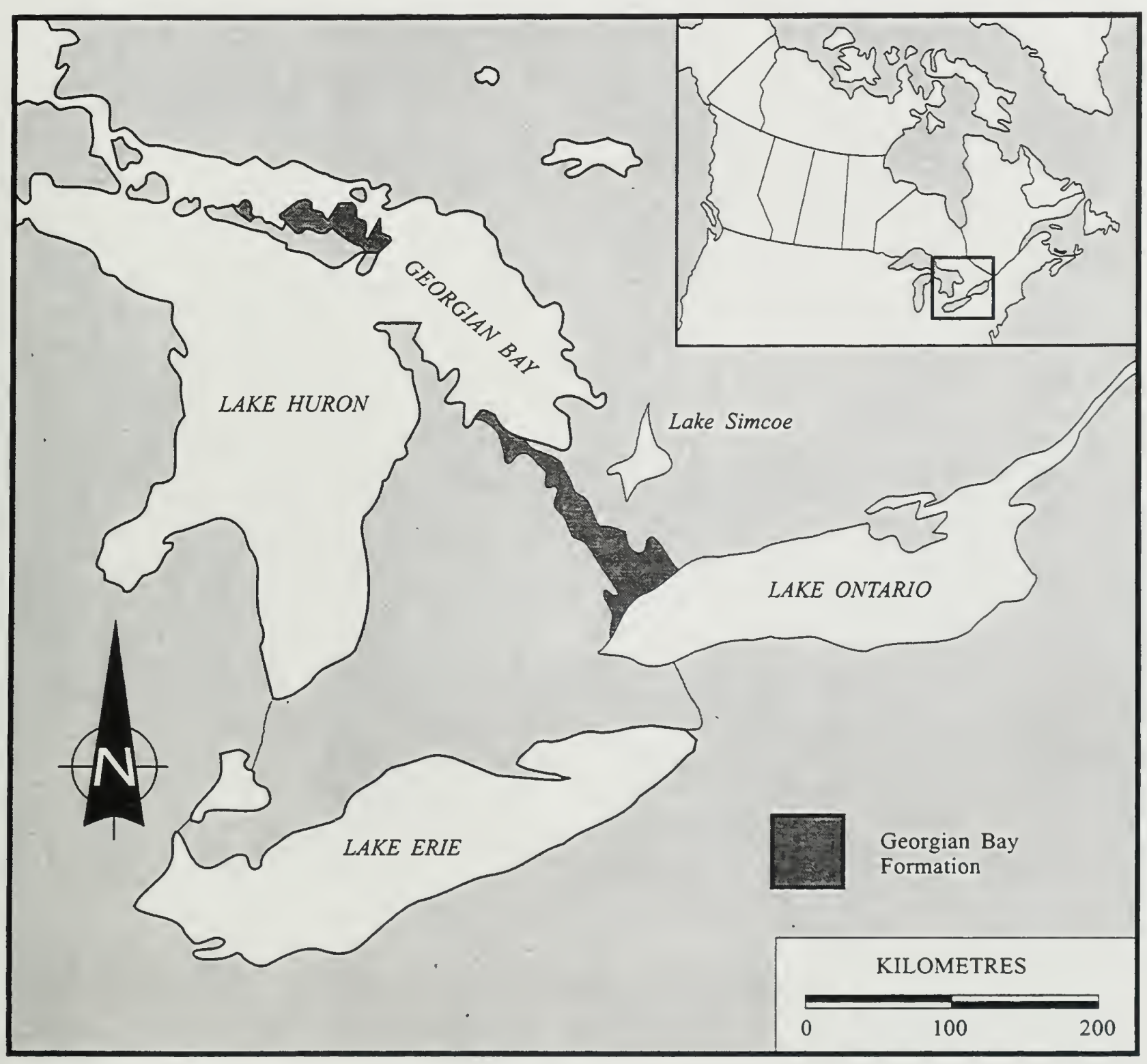

TEXT-Fig. 1. Map of southern Ontario showing extent of Georgian Bay Formation and place names referred to in text. 


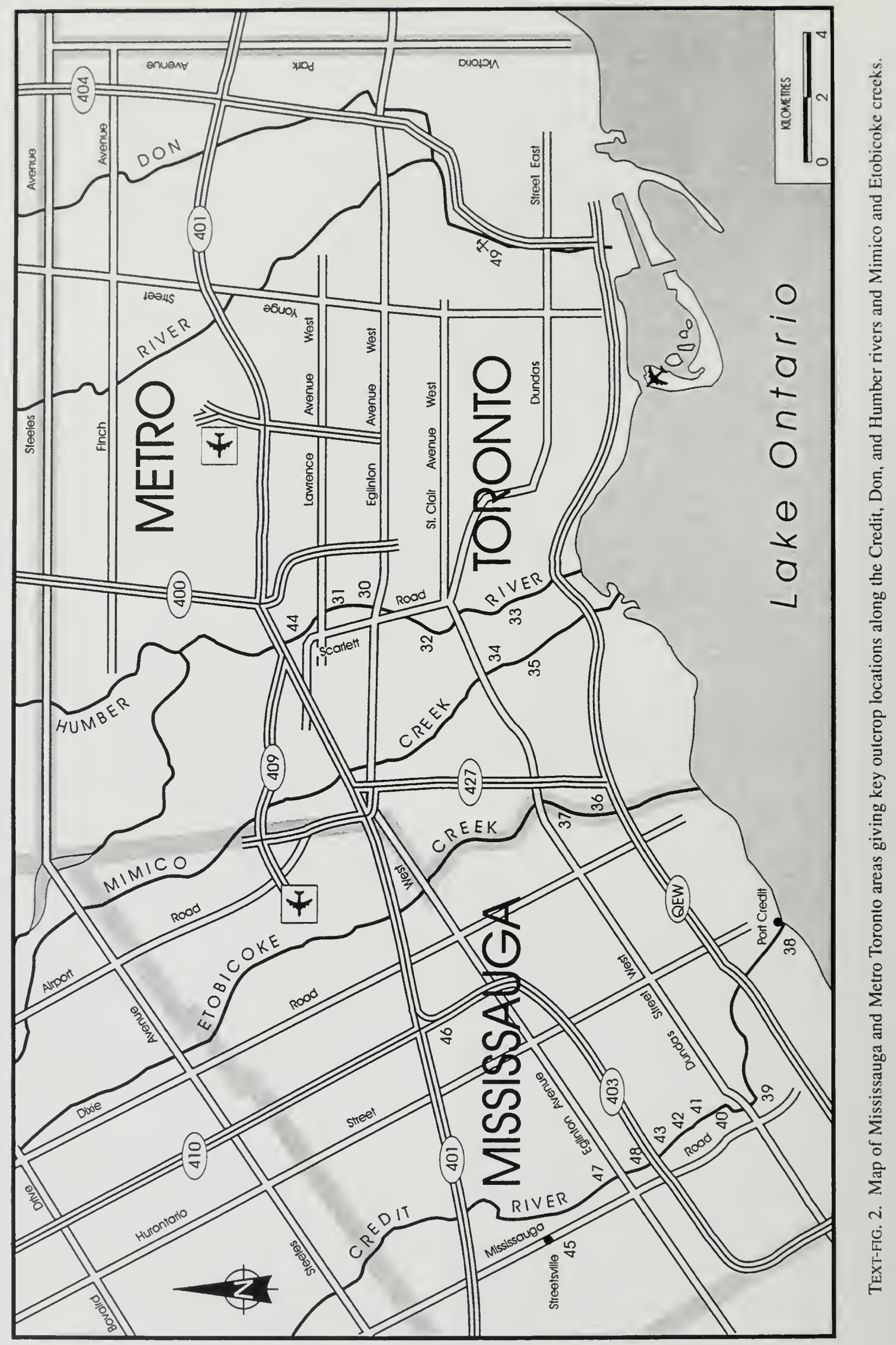




\section{Systematic Ichnology}

\section{INTRODUCTORY REMARKS}

Updated synonymies have been undertaken for those ichnotaxa lacking recent systematic studies or that have numerous poorly classified examples in need of revised taxonomic assignments. These include Arenituba Stanley and Pickerill, 1995; Cochlichnus Hitchcock, 1858; and Fustiglyphus Vialov, 1971. The synonymies for Fustiglyphus and Arenituba have already been published by us (respectively, Stanley and Pickerill, 1993a, 1995), and are therefore not repeated, while that for Cochlichnus is presented herein. Ichnotaxa such as Diplocraterion Torell, 1870, Palaeophycus Hall, 1847, Planolites Nicholson, 1873, and Skolithos Haldeman, 1840, have received detailed systematic treatment by, respectively, Fürsich (1974), Pemberton and Frey (1982), and Alpert (1974). Han and Pickerill (1994a, 1995) have also recently provided detailed discussions on, respectively, Phycodes Richter, 1850, and Helminthopsis Heer, 1877. The latter has also received detailed discussion by Wetzel and Bromley (1996).

Several ichnotaxa from the Georgian Bay Formation have been figured in earlier works (Fritz, 1925; Kerr and Eyles, 1991). Fritz included Chondrites von Sternberg, 1833; Diplocraterion biclavatum (Miller, 1875); Phycodes flabellus (Miller and Dyer, 1878a); Palaeophycus tubularis (Hall, 1847); Rusophycus pudicus Hall, 1852; and Trichophycus venosus Miller, 1879. Kerr and Eyles included Chondrites; Cruziana problematica (Schindewolf, 1921); Didymaulichnus Young, 1972; Diplocraterion biclavatum, Monomorphichnus lineatus Crimes et al., 1977; Palaeophycus striatus Hall, 1852; Palaeophycus tubularis, Rusophycus carbonarius Dawson, 1864; and Trichophycus venosus.
In order to avoid an unnecessarily lengthy citation list, the dates of publication of ichnotaxa are given only for those that are described in this work, this action being in agreement with Article 22 of the International Code of Zoological Nomenclature (ICZN), which states that the "citation of the date of publication of a name is optional." All material figured herein is housed in the Department of Invertebrate Palaeontology, Royal Ontario Museum, Toronto, Ontario, Canada, and specimens are designated by numbers bearing the prefix ROM. Several older museum specimens may bear two numbers following this prefix. The first is the number assigned to the specimen during the production of a standardized catalogue in the 1970s. The second, found within brackets, signifies the old catalogue number by which the specimen was referred to in early works such as Fritz (1925) (see Waddington et al., 1978). A list of all ROM material, along with the respective ROM catalogue numbers, is given in Appendix 1. Additional material is housed in the Department of Geology, University of New Brunswick, Fredericton, New Brunswick, Canada.

Because of poor preservation some material is considered unworthy of detailed description. This includes examples of Arenicolites isp. (ROM 49767, 50049), Lockeia siliquaria James (ROM 50076), and Rusophycus carbonarius Dawson (ROM 50083), which, although not described, do contribute to the overall diversity of the trace-fossil material, and for completeness and possible future reference purposes they are also included in the ROM collections as well as in Appendix 1.

Ichnogenus Arenituba Stanley and Pickerill, 1995

\section{TYPE ICHNOSPECIES}

Micatuba verso Chamberlain, 1971 a, by monotypy.

\section{DIAGNOSIS}

Generally irregularly arranged, sometimes branched tubes radiating from a central gallery, singly or bunched, straight, curved, winding, or sinuous, smooth to finely annulate, sand-coated or -filled (after Stanley and Pickerill, 1995).

DISCUSSION

See Stanley and Pickerill, 1995.
Arenituba verso (Chamberlain, 1971a)

Pl. 1, fig. 1

Arenituba verso Stanley and Pickerill, 1995, fig. 2.

DIAGNOSIS

As for ichnogenus.

MATERIAL

One specimen: ROM 49640.

DESCRIPTION AND REMARKS

See Stanlcy and Pickerill, 1995. 
TYPF: ICHNOSIPECIF.S

Arthraria antiquata Billings, 1872 , by monotypy.

\section{DIAGNOSIS}

Dumbbell-shaped trace fossil parallel to stratification, preserved in convex hyporelief, composed of a shallower stem connecting two wider and more deeply impressed terminations, both of which are commonly hemispherical, but heart, dogbone, and arrowhcad shapes in various combinations occur. Terminations do not extend vertically upwards and vertical tubes and spreiten are absent (after Fillion and Pickerill, 1984a).

\section{DISCUSSION}

Detailed examination of Arthraria was undertaken by Fillion and Pickerill (1984a). A discussion of its distinguishing features with respect to Bifungites and Diplocraterion is presented later in the remarks on $D$. cf. biclavatum.

\section{Arthraria antiquata Billings, 1872}

Pl. 1, fig. 2

\section{MATERIAL}

One specimen: ROM 50050.
DIAGNOSIS

Smooth Arthraria typically preserved in convex hyporelief (after Fillion and Pickerill, 1990a).

\section{DESCRIPTION}

Specimen prescrved as a dumbbell-shaped convex hyporelief, $2.4 \mathrm{~cm}$ in length. Two smooth hemispherical terminations, 4-5 $\mathrm{mm}$ in length by $6-7 \mathrm{~mm}$ in width, are separated from each other by a $4 \mathrm{~mm}$ wide, smooth connecting rod $15 \mathrm{~mm}$ in length. Of the two terminations, one is more deeply impressed ( $3 \mathrm{~mm}$ ) than the other, which is of similar depth to the connecting rod $(2 \mathrm{~mm})$.

\section{REMARKS}

To date, Arthraria is monoichnospecific; the material is therefore assigned to $A$. antiquata. The most effective criterion for distinguishing $A$. antiquata from specimens of the morphologically similar ichnotaxon Diplocraterion in the Georgian Bay Formation is connecting-rod morphology. Arthraria bears a connecting rod that is more or less flat, whereas that of Diplocraterion tends to arch as a result of the characteristic U-shaped morphology of the latter. In many cases, this results in a pinching-out of the connecting rod proximal to the dumbbell terminations. Additionally, size of $A$. antiquata is considerably smaller than Diplocraterion, and compares favourably to type material of the former ichnotaxon.

\section{Ichnogenus Aulichnites Fenton and Fenton, 1937}

\section{TYPE ICHNOSPECIES}

Aulichnites parkerensis Fenton and Fenton, 1937, by original designation.

\section{DIAGNOSIS}

Preserved in convex epirelief with a bilobate upper surface. May show a unilobate, convex-downward lower surface, in which case lateral margins of both surfaces intersect. Upper surface may show transverse, concave-convex striations. Lobes separated by median furrow (after Hakes, 1977).

\section{DISCUSSION}

Aulichnites was erected by Fenton and Fenton (1937) for bilobed traces preserved as convex epireliefs. Comparisons between this ichnogenus and other bilobate traces followed. Chamberlain (1971b) placed Aulichnites in synonymy with Scolicia de Quatrefages, offering virtually no discussion supporting this action, which was later rejected by Häntzschel (1975). Hakes (1977) discussed the validity of maintaining Aulichnites as a separate ichnogenus from
Scolicia and Taphrhelminthopsis Sacco, suggesting that a re-examination of type material of Scolicia was required to determine whether Aulichnites should remain separate. Distinction between Aulichnites and Taphrhelminthopsis can be made on the basis that while the former occurs exclusively as a convex epirelief or concave hyporelief, the latter occurs only as convex hyporeliefs. Książkiewicz (1970, 1977) suggested that rare specimens of Taphrhelminthopsis are preserved as convex epireliefs; however, we believe that such material should more correctly be assigned to Aulichnites.

Similarities were noted by Fillion and Pickerill (1990a) between Aulichnites and Bolonia Meunier; however, in the latter the median furrow is more prominent than the associated lobes. Additionally, as Bolonia is more concave than convex, it is more comparable to Chevronichnus Hakes. Psammichnites Torell, which may also take the form of bilobate ribbons preserved in convex epirelief, can be distinguished from Aulichnites through the latter's lack of "a well-developed medial groove [or] a medial ridge corresponding to the upper surface medial furrow" when pre- 
served in concave hyporelief (Hakes, 1977:218). Psammichnites is generally longer and flatter, with steep margins and a central sinusoidal furrow in epirelief, as well as being wider and less winding than Aulichnites (Hofmann and Patel, 1989). The lobes of Psammichnites also may bear transverse to somewhat oblique striellae (Fillion and Pickerill, 1990a).

\section{Aulichnites parkerensis Fenton and Fenton, 1937}

Pl. 1, fig. 3

\section{MATERIAL}

Two specimens: ROM 50051-50052, plus additional field occurrences.

\section{EMENDED DIAGNOSIS}

Sinuous to straight, unbranched, bilobate positive epirelief traces having a narrow median furrow. Surfaces of the lobes may bear weak transverse concave-convex striations (modified after Howard and Frey, 1984; Frey and Howard, 1990).

\section{DESCRIPTION}

Specimens are preserved as gently curved to winding, bilobate, convex epireliefs, 7-15 mm in width by $130-230 \mathrm{~mm}$ in length. Lobes either are smooth or display faint striations oriented $45^{\circ}$ to the midline. Widths of individual lobes range from $3 \mathrm{~mm}$ to $8 \mathrm{~mm}$ and may vary within a specimen. The median furrow varies in width from $0.5 \mathrm{~mm}$ to $2 \mathrm{~mm}$.

\section{REMARKS}

Several examples appear to display a tendency towards level-crossing, suggesting comparison with the ichnogenus Gordia Emmons. However, unlike Gordia, in which such level-crossing occurs within single specimens, the majority of Aulichnites displaying this feature are in fact specimens crossing one another, but not themselves. One specimen (ROM 50051) does, however, follow a coiled path, producing an apparent level-crossing.

\section{Ichnogenus Chondrites von Sternberg, 1833}

\section{TYPE ICHNOSPECIES}

Fucoides antiquus Brongniart, 1828, by subsequent designation of Miller (1889:114).

\section{DIAGNOSIS}

Dendritic, smooth-walled, regularly ramifying small burrow systems that normally do not interpenetrate or interconnect. Diameter of components within a given system remains essentially constant (after Pemberton and Frey, 1984).

\section{DISCUSSION}

Since the erection of Chondrites in 1833, over $170 \mathrm{ich}-$ nospecies have been recognized in the literature, in many cases based only on slight differences in size or form (Chamberlain, 1971b). Additionally, Häntzschel (1975) recognized 17 ichnogenera as being synonymous with Chondrites. Although the possibility that Chondrites may have been produced by something other than algae was first suggested by Nathorst in 1881 (in Osgood, 1970), it was one of the last fucoids to be recognized as a trace fossil, being described exclusively as of algal origin until Richter (1927) described the phenomenon of phobotaxis (fear of touching) in C. bollensis (Zicten), in which it was observed that branches running on a "collision course" with other branches appeared to terminate just short of contact. This was thought by Richter (1927) to be indicative of an organism attempting to gain maximum efficiency in feeding by not reworking sediment already exploited. Alternatively, Simpson (1957) suggested that Chondrites was produced by an organism resting on the surface, using an extendable proboscis to explore the sediment beneath it for nutrients. This was accomplished by first exploring the sediment directly to the maximum distance from the organism, and then, working backwards along this initial burrow, producing offshoots, the unworked areas being restricted to one side of previous explorations. Phobotaxis was therefore used by the animal to avoid contact with previously covered ground. The principal difference between these two explanations is that the former suggested phobotaxis was used as an aid in ensuring a systematic coverage of an area, whereas the latter suggested that it was used to eliminate repeated excavation of territory during a more or less random approach to feeding. More recent discussions on the ichnotaxon have been presented, particularly with respect to its formation (Kotake, 1991) and as an indicator of anaerobic conditions (Bromley and Ekdale, 1984). Additionally, Vossler and Pemberton (1989) have discussed its possible role as an indicator of opportunistic species.

\section{Chondrites isp.}

Pl. 1, fig. 4

Buthotrephis subnodosa Fritz, 1925:26, pl. 3, fig. 7. Chondrites Kerr and Eyles, 1991, fig. 10b.

\section{MATERIAL}

Four slabs, each containing numerous specimens: ROM 17497 and ROM 50053-50055, plus additional ficld occurrences. 


\section{DH.SCRIPTION}

Specimens consist of dichotomously branched, smooth burrow's preserved as concave to flat epireliefs with up to four orders of branching. Individual burrows never interpenetrate. Branches typically terminate just short of contact as if on a "collision course" with another branch. More rarcly (in threc instances) two branches cross over one another without interpenctrating. Burrow cross-sections arc elliptical, presumably a result of compaction. Disappearance of branches beneath the surface suggests the presence of a three-dimensional structure. Burrows display a relatively uniform diameter of 2-3 mm. Angles of bifurcation range from $23^{\circ}$ to $48^{\circ}$, though one small system has angles ranging from $53^{\circ}$ to $65^{\circ}$. Burrow-fill is a structureless, lighter, finer-grained micrite, though some specimens display a black fill.

\section{REMARKS}

Given the state of taxonomic disarray of Chondrites, ichnospecific assignment of these specimens is considered unrealistic. Comparison can be made, however, to Osgood's (1970) broad group "Chondrites Type B," described as groupings of tunnels, $1-4 \mathrm{~mm}$ in diameter, with a high contrast between filling and host rock, with tunnels piercing bedding planes and up to five orders of bifurcation ranging from $20^{\circ}$ to $40^{\circ}$. Given the recognition of Buthotrephis Hall as for the most part synonymous with Chondrites (Häntzschel, 1975), some specimens of $B$. palmata Hall having been regarded as more akin to Phycodes Richter (Fillion and Pickerill, 1990b), ROM 17497 [1258HR] should be regarded as Chondrites isp. It should be noted that while Fritz (1925, pl. 3, fig. 6) assigned ROM 17497 [1258HR] to B. subnodosa in the text, the corresponding figure caption referred the specimen to $B$. gracilis Hall.

\section{Ichnogenus Cochlichnus Hitchcock, 1858}

\section{TYPE ICHNOSPECIES}

Cochlichnus anguineus Hitchcock, 1858, by monotypy.

non Cochlichnus serpens Webby, 1970:97-99 (partim),

figs. $16 \mathrm{a}-\mathrm{b}$ (=Helminthopsis).

non Cochlichnus isp. Crimes, Legg, Marcos, and Arboleya, 1977:118 (partim), pl. 8a (=Taphrhelminthopsis circularis); Courel, Demathieu, and Gall, 1979:384, pl. 5, fig. 4 (=Helminthopsis); Pickerill, 1980, fig. 3a (partim) (=Helminthopsis).

non Cochlichnus Eagar, Okolo, and Walters, 1983:293, pl.

24f (=Helminthopsis); Pieńkowski and WestwalewiczMogilska, 1986:62, fig. 4b (=Helminthopsis); Narbonne, 1984:408, fig. 7g (=Helminthopsis).

\section{DIAGNOSIS}

Regularly meandering, horizontal trails and burrows resembling sine curves. Sinuosity of the trail may be extremely regular or somewhat irregular (after Pemberton and Frey, 1984; Fillion and Pickerill, 1990a).

\section{DISCUSSION}

Originally monoichnospecific, several new ichnospecies of Cochlichnus have been established since its formulation by Hitchcock in 1858, namely, $C$. antarcticus Tasch, $C$. annulatus Orlowski, C. duomaensis Yang, C. kochi Ludwig, C. lagartensis Muniz, C. serpens Webby, C. surpuliformis Yang and Hu, and $C$. sousensis Muniz. With the exception of $C$. annulatus, the vast majority of specimens assigned to these more recently erected ichnospecies can casily be assigned to $C$. anguineus, as can specimens described by other authors as either Cochlichnus or Cochlichnus isp. (see synonymy). Crimes et al. (1977, pl. 6d) illustrated one specimen of $C$. anguineus as Cochlichnus isp. However, the list of plates illustrating this form incorrectly cites plates $6 \mathrm{~d}$ and $8 \mathrm{a}$, and the latter depicts a specimen of Taphrhelminthopsis circularis Crimes, Legg, Marcos and Arboleya, as is correctly indicated in the figure's caption.

Courel et al. (1979) figured a specimen from the Middle Triassic of France. Although a portion of the trace displays a sinusoidal form typical of Cochlichnus, the remainder is more characteristic of Helminthopsis Heer. When faced with such "compound specimens," we follow the suggestion of Pickerill (1994) and Pickerill and Narbonne (1995) that the assigned name reflect the dominant morphology present. As more than half of the specimens figured by Courel et al. (1979, pl. 5, fig. 4) lack a sinusoidal form, the ichnogenus is best identified as Helminthopsis. Eagar et al. (1983), Narbonne (1984), and Pieńkowski and Westwalewicz-Mogilska (1986) illustrated specimens as Cochlichnus isp. that do not display a truly sinusoidal form; these, too, are best assigned to the more irregularly meandering ichnotaxon Helminthopsis. Material figured by Crimes and Crossley as their newly erected Helminthopsis regularis was described as "stringlike burrows in fairly regular sine curves, which are of greater wavelength than amplitude" (Crimes and Crossley, $1991: 38$, figs. $4 c-d, 5 m-n)$. However, this diagnosis provides no distinction between $H$. regularis and Cochlichnus, both being sinusoidal forms whose wavelength is greater than their amplitude. In their discussion, Crimes and Crossley suggested that these two forms could be distinguished on the grounds that Cochlichnus displays a greater amplitude-to-wavelength ratio and is much larger in bur- 
row diameter than $H$. regularis. However, as no boundary figure for separating these two forms based on the statistical analysis of amplitude-to-wavelength ratios was proposed, and as size is generally considered a poor ichnotaxobase for the distinction of two ichnogenera (cf. Pickerill, 1994), H. regularis is best considered a junior synonym of $C$. anguineus (see also Han and Pickerill, 1995; Wetzel and Bromley, 1996).

Rindsberg (1994:42) erected the ichnogenus Cymataulus for "horizontal, branched or simple, wavy burrows of relatively short wavelength," recognizing two ichnospecies, $C$. undulatus and $C$. kochi. While this ichnogenus was erected with the intention of recognizing a distinction between sinusoidal trails (Cochlichnus) and burrows (Cymataulus), such a distinction is in practice difficult if not impossible to make, as most specimens of each of these ichnotaxa are preserved as top or bottom surface reliefs. Rindsberg's (1994) recognition of Cymataulus kochi based on the presence of branching is a dubious assignment because many of the specimens believed by him to display branching in fact portray intersection of two unrelated traces (e.g., Eagar et al., 1985). In view of these problems, Cymataulus and its two associated ichnospecies are best regarded as junior synonyms of Cochlichnus anguineus.

\section{Cochlichnus anguineus Hitchcock, 1858}

Pl. 2, fig. 1; Pl. 11, fig. 4

Cochlichnus anguineus Hitchcock. Häntzschel, 1962; W188, fig. 116.1; Pickerill, 1981:42, fig. 2c; 1992:26, fig. 4f; Archer and Maples, 1984:449, fig. 3c; Pemberton and Frey, 1984:289, fig. 5a; McCann and Pickerill, 1988:334, fig. 3, no. 7; Dam, 1990:125-126, fig. 6a; Metz, 1989:212, fig. 1b; 1992:30, fig. 1; 1995:44, fig. 1a; 1996:121, fig. 3A; Buatois and Mángano, 1990, fig. 2; 1993:241, fig. 3d; Fillion and Pickerill, 1990a:23, pl. 3, fig. 3; Crimes and Crossley, 1991:44, figs. 8a-b; Mikuláš, 1992:391-392, pl. vi, fig. 2; McCann, 1993:42, fig. 4c; Han and Pickerill, 1994b:225, fig. 3F; Gluszek, 1995, figs. 5, 7-8, 15A; Archer, Calder, Gibling, Naylor, Reid, and Wightman, 1995:2032, fig. 5d; Buatois, Mángano, Wu, and Zhang, 1996:293, figs. 8A-B.

Cochlichnus aff. anguineus Hitchcock. Książkiewicz 1977:151-152, pl. 20, fig. 1; 166, figs. p-q.

Cochlichnus isp. Kemper, 1968, pl. 7, fig. 5; Tasch, 1968b:191, figs. 2a-c; Aceñolaza and Durand, 1973:50, pl. 2c; Crimes, Legg, Marcos, and Arbolcya, 1977:118, pl. 6d; Roniewicz and Pieńowski, 1977, pl. 1c; Aceñolaza, 1978:24, fig. 6; Palij, Posti, and Fedonkin, 1983, pl. 54, figs. 3-4, 6-7; Liñán, 1984:59-60, pl. 2, figs. 8b, 9; Demathicu, 1985, pl. 1b; Crimes and Anderson, 1985:317, figs. 6.1-2; McCann,
1990, fig. 4c; Mikuláš, 1991, pl. 4, fig. 5; Hofmann, Cecile, and Lane, 1994:733, figs. $5 \mathrm{i}-\mathrm{j}$.

Cochlichnus Hakes, 1976:23-24, pl. 5.5; 1985, pl. 1f; Miller, 1984, pl. 5f; Eagar, Baines, Collinson, Hardy, Okolo, and Pollard, 1985:138, pls. 3c, 12e-f; Miller, 1986:199, pl. 12b; Crimes, 1987:104, fig. 2c; Bjerstedt, 1987:877, fig. 9.5 ; 1988, fig. 4e.

Cochlichnus antarcticus Tasch, 1968a:35-36, figs. 1-2.

Cochlichnus kochi Ludwig. Häntzschel, 1975:W52, fig. 31.1; Elliott, 1985:185, fig. 2.

Cochlichnus serpens Webby, 1970:97-99 (partim), figs. $16 \mathrm{c}-\mathrm{f}$.

Cochlichnus lagartensis Muniz, 1980:3101-3103.

Cochlichnus sousensis Muniz, 1985:239-240, fig. 1.

Cymataulus kochi Rindsberg, 1994:42.

Cymataulus undulatus Rindsberg, 1994:42-43, pl. 7c-d.

Helminthopsis regularis Crimes and Crossley, 1991:38, figs. $4 \mathrm{c}-\mathrm{d}, 5 \mathrm{~m}-\mathrm{n}$.

Biting midge trail Metz, 1987:312-313, fig. 1.

\section{MATERIAL}

One specimen: ROM 49427.

\section{DIAGNOSIS}

Smooth Cochlichnus (after Fillion and Pickerill, 1990a).

\section{DESCRIPTION}

Smooth, unbranched, sinusoidal burrow, $9 \mathrm{~mm}$ in length and displaying a wavelength of approximately $0.8 \mathrm{~mm}$ and an amplitude of approximately $0.8 \mathrm{~mm}$. Diameter of burrow $0.1-0.2 \mathrm{~mm}$. Specimen preserved in convex hyporelief.

\section{REMARKS}

Possible progenitors of this ichnospecies include annelids lacking well-developed parapodia (Hitchcock, 1858; Hakes, 1976), nematodes lacking circular muscles (Clarke, 1964), and, in subaerial deposits, insect larvae (Metz, 1987).

Cochlichnus n. isp.

Pl. 2, fig. 2

\section{MATERIAL}

One specimen: ROM 50056.

\section{DESCRIPTION}

Specimen preserved as an unlined, sinusoidal burrow, 11 $\mathrm{mm}$ in diameter, in convex epirelief. Amplitude is $15 \mathrm{~mm}$ and wavelength $45 \mathrm{~mm}$, while the overall course curves slightly. Surface of trace bears at least seven distinct, sharply defined striations varying from $0.3 \mathrm{~mm}$ to $1 \mathrm{~mm}$ in width. Individual striations do not run the entire length of the trace, though there is no systematic alternation of striate and smooth portions. 


\section{REMARKS}

While this specimen clearly represents a previously undescribed ichnospecies of Cochlichnus through the presence of well-defined longitudinal striations, until additional material is found, it is inadvisable to erect a new ichno- species to accommodate it at this time. The fact that the present specimen is preserved as a convex epirelief indicates that it must have been produced by an organism's burrowing rather than trail-making activities.

\section{Ichnogenus Cruziana d'Orbigny, 1842}

\author{
TYPE ICHNOSPECIES \\ Cruziana rugosa d'Orbigny, 1842, by subsequent designa- \\ tion (Miller, 1889:115).
}

\section{DIAG.NOSIS}

Elongate, band-like, bilobate or, rarely, unilobate furrows or burrows covered by herringbone-shaped or transverse ridges, with or without two outer smooth or longitudinally striellate zones outside the $\mathrm{V}$-markings, with or without lateral ridges and/or wisp-like markings if preserved on bedding soles (after Fillion and Pickerill, 1990a).

\section{Discussion}

Cruziana was originally proposed by d'Orbigny (1842) to describe bilobate coffee-bean or buckle-like forms that fell within the current concept of Rusophycus Hall. He had initially intended to use the name Bilobites d'Orbigny, but discovered that this name was already in use, having been applied to a pelecypod by Dekay (1824). Soon afterwards, unaware of d'Orbigny's (1842) work, Hall (1852) described as Rusophycus material that was much the same as that described by d'Orbigny as Cruziana. This created a situation where, for the next hundred years or so, confusion reigned and Bilobites, Cruziana, and Rusophycus were used interchangeably for ichnotaxa displaying essentially the same morphological characteristics.

In 1953, Seilacher attempted to clarify the situation by restricting short buckle-like bilobate cubichnial (resting) forms to Cruziana, while longer ribbon-like repichnial (crawling) forms were described as Crossochorda Schimper (Osgood, 1970). In 1955, Seilacher referred all ribbon-like bilobate repichnial traces to Cruziana, while the shorter buckle-like cubichnial traces were described as Rusophycus, and Crossochorda was believed to represent an intermediate form between Cruziana and Rusophycus. In 1970, however, Seilacher changed his position once more to refer all bilobate traces to Cruziana, believing it unnecessary to maintain separate ichnogenera for burrows of different outline that could, in his opinion, be attributed to the same organism through "fingerprinting," a view upheld in a more recent contribution (Seilacher, 1991). This, of course, contravenes the belief held by most ichnologists, including ourselves, that the knowledge of the tracemaker has no significance in ichnological taxonomy
(Sarjeant, 1979, Art. 40). We therefore refer longer ribbonlike repichnial forms to Cruziana, and short buckle-like bilobate cubichnial forms to Rusophycus.

\section{Cruziana cf. lobosa Seilacher, 1970}

PI. 2, fig. 3

\section{MATERIAL}

Three slabs: ROM 35227, ROM 49425, and ROM 49427 , plus additional field occurrences.

\section{DIAGNOSIS}

Deep furrow with almost transverse leg markings that are rounded with blunt ends instead of bearing distinct claw marks. Pleural lobes smooth (after Seilacher, 1970).

\section{DESCRIPTION}

Specimens preserved as straight to meandering convex hyporeliefs, between $5 \mathrm{~mm}$ and $9 \mathrm{~mm}$ in width and 0.25 $\mathrm{mm}$ and $3 \mathrm{~mm}$ in depth, each consisting of a central furrow bearing two parallel rows of rounded endopodial striellae, $1-2 \mathrm{~mm}$ in width, separated by median furrows $0.5-1 \mathrm{~mm}$ wide. Furrows are bordered by smooth pleural lobes $1-2$ $\mathrm{mm}$ wide on either side.

\section{REMARKS}

On specimen ROM 49427, examples of both Cruziana cf. lobosa and Rusophycus cryptolithi Osgood, 1970, are present. In one example (ROM 49427), $R$. cryptolithi is continuous with a specimen of $C$. cf. lobosa, suggesting that the two traces were produced by the same individual, but represent slightly different behaviourial activity. Cruziana lobosa, while similar to C. quadrata Seilacher, 1970, differs in displaying clearly rounded, blunt endopodial striellae, whereas $C$. quadrata bears thinner oblique scratchings.

\section{Cruziana problematica (Schindewolf, 1921)}

Pl. 3, fig. 1

Kerr and Eyles, 1991, fig. 10J.

\section{MATERIAL}

One specimen: ROM 50058, plus numerous field occurrences. 


\section{DIAGNOSIS}

Straight or curved Cruziana, up to $7 \mathrm{~mm}$ wide, showing faint, transverse striellae which can reach the margins of the trace in shallow specimens or terminate before reaching the margins in deeply impressed specimens (after Fillion and Pickerill, 1990a).

\section{DESCRIPTION}

Specimens are preserved as straight to slightly curved, slightly arched, bilobate convex hyporeliefs, 11-24 mm in length by $0.3-0.5 \mathrm{~mm}$ in width. The lobes, $5-12 \mathrm{~mm}$ wide, are covered by poorly to moderately developed striellae, and are separated by a median furrow $0.3-0.5 \mathrm{~mm}$ wide.

\section{REMARKS}

Specimens of Phycodes flabellus can be mistaken for Cruziana problematica in instances where only two parallel annulated branches are clearly displayed on the former. This configuration produces an apparently bilobed structure, the transverse annulations characteristic of $P$. flabellus resembling the striellae found on $C$. problematica. Sectioning of problematic material may reveal the presence or absence of an internal spreiten indicative of Phycodes. The smooth bilobed ichnogenus Didymaulichnus, also present in the Georgian Bay Formation, may have been produced by intense weathering of $C$. problematica. Specimens of both ichnotaxa were found to fall within the same ranges of length and width, the only distinguishing feature of the latter being the presence of striellae covering each lobe.

Cruziana problematica is identical in all respects to the ichnogenus Isopodichnus Bornemann. Criteria historically utilized to distinguish Cruziana and Isopodichnus (all unacceptable ichnotaxobases under any circumstances) have included 1) their relative sizes, 2) their stratigraphic ages, 3) their facies associations, and 4) the supposed identity of their respective producers, the Cruziana believed to have been produced by trilobites, and the Isopodichnus by notostracan branchiopods (Romano and Whyte, 1987; Pickerill, 1994). Bromley and Asgaard (1979) and Romano and Whyte (1987) concluded that Isopodichnus Bornemann be regarded a synonym of Cruziana, a suggestion supported by ourselves, as well as Bromley (1990), Pickerill and Peel (1990), Pickerill (1992, 1994), and Keighley and Pickerill (1996).

\section{Cruziana quadrata Seilacher, 1970}

Pl. 2, fig. 4

\section{MATERIAL}

One specimen: ROM 50059, plus an additional field occurrence.

\section{DIAGNOSIS}

Deep furrow with rectangular cross-section. Narrow endopodial lobe of oblique multiple scratches on either side of median line. Pleural lobe smooth with few transverse scratches (after Seilacher, 1970).

\section{DESCRIPTION}

Specimens are preserved as straight to winding convex hyporeliefs, 4-6 mm wide, up to $90 \mathrm{~mm}$ long. A central region, $2.0-2.5 \mathrm{~mm}$ wide, bearing fine, straight, endopodial striellae, oriented $45^{\circ}-65^{\circ}$ with respect to the long axis of the trace, is bound on either side by pleural lobes $1.0-1.5 \mathrm{~mm}$ wide displaying well-developed transverse scratches at $1-\mathrm{mm}$ intervals.

\section{REMARKS}

Cruziana quadrata, while also bearing distinct pleural lobes, differs from C. lobosa in that endopodial striellae are not blunt or pustulose in appearance on the former; rather, distinct thin scratchings are displayed.

\section{Cruziana ispp.}

Pl. 3, fig. 2

\section{MATERIAL}

Two specimens: ROM 50060-50061; three specimens on one slab: ROM 50062; three specimens on one additional slab: ROM 50063.

\section{DESCRIPTION}

Variably but generally poorly preserved, straight to winding structures, up to $15 \mathrm{~mm}$ in width and $143 \mathrm{~mm}$ in length, preserved in convex hyporelief. Most material is bilobed with individual lobes possessing variably developed transverse scratch markings that in ROM 50063 are locally tricuspate. Specimens in ROM 50063 are essentially unilobate, though a $3-\mathrm{cm}$ portion of one is clearly bilobate.

\section{REMARKS}

Though poor preservation precludes ichnospecific assignment, this material can clearly be assigned to Cruziana. Based on its variable morphology we suspect that more than one ichnospecies is present and include its documentation herein for possible future comparative purposes. 


\section{TY'E: ICHNOSPECIES}

Cunolithus mulriplex Fritsch, 1908, by subsequent designation (Häntzschel, 1962:W189).

\section{F.ME.NDE.I) DIA (..YOSIS}

Band-like horizontal burrows with a trilobate upper surface consisting of two lateral round lobes and a median lobe separated from each other by narrow angular furrows. Width of lateral lobes may be equal to or smaller than the median lobe. A faint central furrow may occur on the median lobe. Lower surface may be bilobate, consisting of two small lateral round lobes and a large median furrow, or quadrilobate, consisting of four lobes separated by three angular furrows. May also be unilobate. Inner portion of lateral lobes may show an angular crest parallel and adjacent to the median furrow (modified after Fillion and Pickerill, 1990a; Maples and Suttner, 1990).

\section{DISCUSSION}

Cunvolithus was erected by Fritsch in 1908 to encompass burrows bearing trilobate upper surfaces. Two ichnospecies were introduced, namely, $C$. multiplex and C. gregarius, the former exhibiting a trilobate upper surface associated with a bilobed lower surface, the latter differing in displaying a quadrilobate lower surface. In 1970 Webby erected $C$.? davidis. While no formal diagnosis was included, Webby's description provided offered no distinguishing features between this ichnospecies and $C$. multiplex, C.? davidis being comprised of "a broad axial ridge and two narrower, marginal ridges separated by relatively narrow shallow grooves" (Webby, 1970:103). In view of this, we tentatively regard $C$.? davidis as a junior synonym of C. multiplex.

Badve and Ghare (1978) introduced Curvolithus annulatus for forms bearing an annulated trilobate upper surface associated with a smooth, rounded lower surface. Walter, Elphinstone, and Heys (1989) described C. aequus to encompass trilobate traces in which the widths of the three lobes were approximately the same. Maples and Suttner (1990) formulated C. manitouensis with material that is indistinguishable from Fritsch's (1908) C. gregar- ius. Maples and Suttner (1990) suggested that the presence of a quadrilobate lower surface distinguished $C$. manirouensis from all other ichnospecies of Curvolithus. However, as both $C$. gregarius and $C$. manitouensis bear trilobate upper surfaces in association with quadrilobate lower surfaces, we regard the former as a senior synonym of the latter.

\section{Curvolithus multiplex Fritsch, 1908}

Pl. 3, fig. 3

\section{MATERIAL}

Two specimens: ROM 50064-50065.

\section{DIAGNOSIS}

Curvolithus with a bilobate lower surface and a trilobate upper surface in which the median lobe is wider than the lateral lobes.

\section{DESCRIPTION}

Specimens preserved as burrows, 9-13 mm wide by 22-36 $\mathrm{mm}$ long, one in full relief, the other as a convex hyporelief. On the former, one surface bears two lateral lobes 1 $\mathrm{mm}$ wide flanking a much broader central lobe $8 \mathrm{~mm}$ wide. A faint central ridge $9 \mathrm{~mm}$ long commences at one end of the trace. The opposing surface displays a central furrow 2 $\mathrm{mm}$ wide bounded on either side by lobes $4 \mathrm{~mm}$ in width. Not as well preserved, the latter specimen bears only one well-developed lateral lobe on the lower surface. The entire surface is covered by fine longitudinal striellae running the length of the trace. The maximum thickness displayed by both specimens is $4 \mathrm{~mm}$.

\section{REMARKS}

As no formal diagnosis of this form could be located, that given above is proposed. While the present specimens are relatively poorly preserved, the characteristic features of Curvolithus multiplex can be discerned. Similarly preserved material has been described by Heinberg (1970, 1973) and Fillion and Pickerill (1990a).

\section{Ichnogenus Didymaulichnus Young, 1972}

Didymaulichnus Kerr and Eyles, 1991, fig. 10e.

\section{TYPE ICHNOSPECIES}

Fraena lyelli Rouault, 1850, by original designation (Young, 1972:10).

\section{DIAGNOSIS}

Smooth, furrow-like horizontal trails or burrows, bisected longitudinally by a narrow median groove if preserved in hyporelief (after Young, 1972). 


\section{DISCUSSION}

When the ichnogenus Didymaulichnus was formally introduced, D. miettensis was erected by Young (1972). Subsequently, five additional ichnospecies have been established, namely, D. lyelli (Rouault), D. rouaulti (Lebesconte), D. tirasensis Palij, D. nankervisi Bradshaw, and D. alternatus Pickerill, Romano, and Meléndez. Of these, we consider $D$. nankervisi to have been inappropriately assigned to Didymaulichnus because one of the diagnostic properties of this ichnospecies was stated to be the presence of "transverse or pit-like depressions on either side of the median ridge" (Bradshaw, 1981:635). Examination of the accompanying plates reveals that this vague and interpretive description refers to transverse or mound-like swellings running along the crests of each lobe. The presence of such a feature is at variance with the diagnosis of the ichnogenus, which requires the lobes to be smooth (Young, 1972). Therefore, we believe that $D$. nankervisi is in fact more akin to Pteridichnites Clarke and Swartz (cf. Fillion and Pickerill, 1990a).

Didymaulichnus can be distinguished from the similar ichnogenus Cruziana through the lack of scratch marks on the lobes. The former ichnogenus is believed to be the work of gastropods (Glaessner, 1969; Hakes, 1976) or trilobites (Crimes, 1970; Bradshaw, 1981).
Didymaulichnus lyelli (Rouault, 1850)

$$
\text { Pl. 3, fig. } 4
$$

\section{MATERIAL}

Two specimens: ROM 49427 and ROM 50066, plus additional field occurrences.

\section{DIAGNOSIS}

Bilobate trail or burrow bisected longitudinally by a shallow groove (in convex hyporelief), without oblique scratches, lateral ridges, marginal bevels, or regularly alternating, deeply impressed sections (after Fillion and Pickerill, 1990a).

\section{DESCRIPTION}

Specimens are preserved as smooth, straight to slightly curved, bilobed convex hyporeliefs, $3.5-4.3 \mathrm{~mm}$ in width, $17-42 \mathrm{~mm}$ in length, and $1.5-2 \mathrm{~mm}$ in depth. A median furrow, $0.3-2 \mathrm{~mm}$ in depth, runs the length of each trace, dividing it into two lobes of equal width, the surfaces of which are seen to be slightly undulatory in places.

\section{REMARKS}

The present material is assigned to Didymaulichnus lyelli due to its lack of 1) marginal bevels seen in D. miettensis and $D$. tirasensis, 2) alternating burrow depths characteristic of D. alternatus, and 3) lateral ridges characteristic of D. rouaulti.

Ichnogenus Diplocraterion Torell, 1870

\section{TYPE ICHNOSPECIES}

Diplocraterion parallelum Torell, 1870 , by subsequent designation (Matthew, 1891:163).

\section{DIAGNOSIS}

Vertical U-shaped spreiten-burrows (after Fürsich, 1974).

\section{DISCUSSION}

This ichnogenus was erected by Torell in 1870 for vertical U-shaped burrows. Subsequently, two morphologically similar ichnogenera were established, namely, Corophioides Smith, and Polyupsilon Howell. The differences between these three ichnogenera have since been a topic of considcrable debate. The primary difference between Corophioides and Diplocraterion was based essentially on the presence of funncl-like openings in the latter (Abel in Goldring, 1962). However, this criterion is now considered an inappropriate ichnotaxobase, as this feature may casily be absent due to weathering effects, leaving two essentially identical structures (Ekdalc et al., 1984). Different development of spreite was used by Knox (1973) to scparate these ichnogenera, though intermediate forms have been found, suggesting a gradational variation within a single ichnogenus (Fürsich, 1974).

Polyupsilon was distinguished from Diplocraterion based on divergence of the U-tube arms in the former as the sediment-water interface was approached, though, as this was only an accessory feature, and as the diagnostic features of Diplocraterion (U-tube with spreite) were present, ichnogeneric level separation was not warranted (Fürsich, 1974). Polyupsilon was regarded as a junior synonym of Corophioides by Knox (1973), and the following year, Fürsich (1974) assigned all vertical spreiten-bearing U-tubes to Diplocraterion.

\section{Diplocraterion cf. biclavatum (Miller, 1875)} Pl. 4, fig. 1; Pl. 5, figs. 1-2

Arthraria biclavata Fritz, 1925:26, pl. 3, fig. 7.

Bifungites Kerr and Eyles, 1991, fig. 10a.

Diplocraterion Kerr and Eyles, 1991, fig. 10d.

\section{MATERIAL}

One slab containing eight examples in ROM collection: ROM 17491 [1252HR] and ROM 50067-50069, plus additional specimens collected in the field. 
DIACiNCSIS

Diplocraterion in which the arms of the U-tube are extended below the base of the deepest $U$ to form blind pouches. The ichnospecies is most commonly preserved as concave epireliefs with a dumbbell shape (after Fürsich, 1974).

\section{DESCRIPTION}

These traces are preserved as dumbbell-shaped concave epirelicfs and convex hyporelicfs. One example is preserved in vertical semirelief and displays protrusive spreiten. Specimens display total lengths varying from $26 \mathrm{~mm}$ to $103 \mathrm{~mm}$. Thickness of the dumbbell terminations varies from $10 \mathrm{~mm}$ to $31 \mathrm{~mm}$. Shape of the terminations is either hemispherical or dogbone. Widths of the connecting bar vary from $2 \mathrm{~mm}$ to $5 \mathrm{~mm}$. In many cases, the connecting bar is arched, being broader and deeper at the centre, tapering and becoming shallower, sometimes pinching out, as each termination is approached. In vertical section, convex hyporeliefs display no overlying structure. Terminal depressions are generally smooth, though some unevenness may be present. In ROM 17491 [1252HR], copperbrown stains occur in association with smooth terminations, though similar stains are seen by themselves elsewhere on the slab, sometimes in pairs. The connecting bar of one example on ROM 17491 [1252HR] passes through the slab, appearing as a short segment on the underside.

\section{REMARKS}

Unequivocal assignment at the ichnogeneric rank of the present material to Arthraria, Bifungites, or Diplocraterion is problematic. Distinction between these ichnogenera is based on the presence or absence of vertical tubes above the terminations and, when present, the structure of the sediment between these tubes (Fillion and Pickerill, 1984a). The material described here is reminiscent of each of these ichnogenera and, because of the lack of any vertical components, is most comparable to Arthraria. However, in the field, numerous occurrences of Diplocraterion in vertical section were observed, whereas no traces that could be unequivocally recognized as Bifungites were identified, and only one example of Arthraria was found. Assignment of the present material to Diplocraterion is considered justified by the significant difference in size of the specimens studied, the majority being much larger than the single specimen of Arthraria. Additionally, the presence of an arched connecting rod, not seen in Arthraria, further suggests assignment to Diplocraterion. As the material is preserved as dumbbell-shaped forms, assignment to $D$. cf. biclavatum is proposed, the terminations most likely being a result of the presence of blind pouches at the base of the burrow characteristic of this ichnospecies (Fürsich, 1974).

\section{DIACNOSIS}

Diplocraterion having an expanded base (after Fürsich, 1974).

\section{DESCRIPTION}

Specimen is preserved in vertical semirelief as a $U$-shaped vertical burrow displaying an expanded base. Distance between the arms is $37 \mathrm{~mm}$, this expanding to a maximum of $72 \mathrm{~mm}$ at the base. Protrusive spreiten are present between the arms. Depth of the trace, as preserved, is 150 $\mathrm{mm}, 37 \mathrm{~mm}$ of which is the expanded base. Diameter of the tubes is $6 \mathrm{~mm}$.

\section{REMARKS}

In addition to $D$. helmerseni, Fürsich (1974) recognized four other ichnospecies in his study of vertical, spreitenbearing, U-shaped trace fossils, namely, D. parallelum Torell, $D$. biclavatum, $D$. habichi (Lisson), and D. polyupsilon (Smith) (see also Bromley, 1990:157). ROM 48896 can be distinguished from these in that it possesses a basal expansion not seen in $D$. parallelum, lacks the blind pouches characteristic of $D$. biclavatum, does not display divergent arms characteristic of $D$. habichi, and lacks any evidence of bidirectional spreite as seen in D. polyupsilon.

\section{Diplocraterion parallelum Torell, 1870} Pl. 4, fig. 3

\section{MATERIAL}

One specimen: ROM 50071, plus numerous field occurrences.

\section{DIAGNOSIS}

Diplocraterion having parallel arms and a unidirectional spreite (after Fillion and Pickerill, 1990a).

\section{DESCRIPTION}

Specimens are preserved in endorelief as $U$-shaped tubes in vertical section, sometimes displaying dumbbell-shaped semireliefs on associated top surfaces. Dimensions vary between $19 \mathrm{~mm}$ and $55 \mathrm{~mm}$ in width by $43 \mathrm{~mm}$ to $63 \mathrm{~mm}$ in depth. Arms are for the most part parallel, though in some instances a slight flaring at the base is present, reminiscent of $D$. helmerseni. Protrusive spreiten are present, individually separated by intervals of $1-4 \mathrm{~mm}$. Where present, burrow-arm fill is identical to the host rock.

\section{REMARKS}

The slight widening of the arms towards the base of one individual suggests that a gradation between $D$. helmerseni and $D$. parallelum may be present.

Diplocraterion helmerseni (Öpik, 1929)

PI. 4, fig. 2

MATERIAL

One specimen: ROM 48896. 
TYPE ICHNOSPECIES

Fustiglyphus annulatus Vialov, 1971:91, fig. 3, by monotypy.

\section{DIAGNOSIS}

Straight horizontal strings or narrow cylinders of varying length encircled at regular or varying intervals by ring-like "knots" or well-defined swellings that display no bifurcation or invagination; rosary-like. Preserved in convex hyporelief or concave epirelief (after Stanley and Pickerill, 1993a).

\section{DISCUSSION}

See Stanley and Pickerill, 1993a.

Fustiglyphus annulatus Vialov, 1971

Pl. 5, fig. 3

Fustiglyphus annulatus Stanley and Pickerill, 1993a, figs. 2-3.

\section{MATERIAL}

Five specimens: ROM 49465 and ROM 49467-49470.

\section{DIAGNOSIS}

Unbranched Fustiglyphus bearing spherical-, hemispherical-, heart-, or ring-shaped (either singly or paired) swellings. An individual specimen may be comprised entirely of one type of swelling or of combinations of two or more (after Stanley and Pickerill, 1993a).

\section{DESCRIPTION AND REMARKS}

See Stanley and Pickerill, 1993a.

\section{Ichnogenus Gordia Emmons, 1844}

TYPE ICHNOSPECIES

Gordia marina Emmons, 1844, by monotypy.

\section{DIAGNOSIS}

Unbranched, predominantly horizontal trails or burrows that wind or loop but do not regularly meander, with a marked tendency to level-crossing. Burrow-fill structureless (after Pickerill and Peel, 1991).

\section{DISCUSSION}

Gordia was erected by Emmons (1844) for smooth traces that resembled the freshwater worm Gordius. Helminthopsis and Helminthoidichnites Fitch can be distinguished from Gordia by their lack of consistent levelcrossing. Helminthoidichnites can be further distinguished from Gordia through the latter's greater tendency to display a non-random behaviour, as revealed through computer simulation studies undertaken by Hofmann (1991). Haplotichnus Miller can be distinguished from Gordia by its sharply angled bends, and Mermia Smith by its more intense looping and thinner burrow diameter. Five additional ichnospecies of Gordia have been established since its formulation, namely, G. molassica (Heer), G. arcuata Książkiewicz, G. hanyagensis Yang and Hu, G. maeandria Jiang, and G. nodosa Pickerill and Peel. Of these, two have been regarded as possible junior synonyms of $G$. marina, namely, G. molassica and G. hanyagensis (Pickerill, 1981; Fillion and Pickerill, 1990a).

\author{
Gordia marina Emmons, 1844 \\ Pl. 5, fig. 4
}

\section{MATERIAL}

One specimen: ROM 50072.

\section{DIAGNOSIS}

Gordia in which level-crossing is fully developed and meanders are unguided (after Fillion and Pickerill, 1990a).

\section{DESCRIPTION}

Specimen preserved in convex hyporelief as an unguided, irregularly winding, unornamented burrow, approximately $14 \mathrm{~cm}$ in length, and maintaining a uniform diameter of 0.5 $\mathrm{mm}$ throughout its largely horizontal course. The burrow either interpenetrates or passes underneath itself. Faint constrictions and nodes are seen in places. Burrow-fill is similar to the host rock.

\section{REMARKS}

The available material is assigned to Gordia marina based on the presence of unguided meanders and level-crossings. It differs from $G$. arcuata in that its course is fully developed rather than consisting just of apical bends, G. maeandria in displaying unguided meanders and level-crossings, and $G$. nodosa by lacking the regularly or irregularly spaced annulations characteristic of the latter. 
TYPE ICHYOSPECIES

Gyrochorte comosa Hecr, 1865, by subsequent designation (Häntzschel, 1962:W196).

\section{EMENDED DIAGNOSIS}

Horizontal burrows preserved in epirelicf having biserially arranged, obliquely aligned, transverse plaits separated by a median furrow. The entire burrow complex may consist of vertically repetitive, more or less identical modular units. Traces may be associated with hypichnial, smooth, winding, bilobate grooves of similar dimensions and course to the epichnial counterpart (after Hallam, 1970; Pemberton and Frey, 1984).

\section{DISCUSSION}

As reviewed in Hallam (1970), since its formulation, the ichnotaxon Gyrochorte has been interpreted as having been produced by molluscs or worms moving along the sediment-water interface (Heer, 1865), the tunnelling or crawling activity of amphipods, and infaunal worm-like organisms (Heinberg, 1973). Heinberg's (1973) exceptionally well preserved material from the Cretaceous of Greenland suggested that it was best interpreted as having been produced by a deposit-feeding worm-like organism moving obliquely through the sediment, a conclusion also supported herein.

To our knowledge, eight ichnospecies have been assigned to Gyrochorte, namely, G. burtoni Książkiewicz, ' $G$ ' . carbonaria Pollard, G. comosa, ?G. dubia Sacco, $G$. imbricata Książkiewicz, G. obliterata Książkiewicz, $G$. ramosa Heer, and $G$. vermicularis Heer. Of these, ?G. dubia is regarded as a nomen dubium, and ' $G$ '. carbonaria as a nomen nudum; the taxonomic status of the remaining ichnospecies requires further evaluation.

\section{Gyrochorte comosa Heer, 1865}

Pl. 6, fig. 1

Gyrochorte comosa Pickerill, 1994, fig. 1.3 (partim).

\section{MATERIAL}

Two specimens: ROM 50073 (partim) and ROM 50074, plus additional field occurrences.

\section{DIAGNOSIS}

As for the ichnogenus.

\section{DESCRIPTION}

Specimens preserved as horizontal, meandering, bilobate, convex epireliefs, $2-3 \mathrm{~mm}$ in width. Obliquely arranged biserial transverse segmentation, with from five to seven segments per $\mathrm{cm}$, runs along the length of the specimens, which range from $50 \mathrm{~mm}$ to $75 \mathrm{~mm}$ in length. The angle between this segmentation and the median groove ranges from $45^{\circ}$ to $70^{\circ}$.

\section{REMARKS}

Specimens of Gyrochorte comosa form compound specimens (sensu Pickerill, 1994) with the ichnotaxa Planolites annularius Walcott and $P$. beverleyensis (Billings). Such specimens demonstrate the fact that one organism can display different behaviours, thereby producing more than one ichnotaxon. The example illustrated in Plate 6, fig. 1 , would have been produced by an organism, possibly an annelid, moving through the sediment first in an oblique manner to produce Gyrochorte comosa, then changing its behaviour to burrowing horizontally to produce $P$. beverleyensis, followed by a change to movement involving peristaltic muscular contractions to produce $P$. annularius.

Gyrochorte comosa can be distinguished from other existing ichnospecies of Gyrochorte by its lack of 1) oblique incisions characteristic of $G$. burtani Książkiewicz, 2) imbricate asymmetrical riblets characteristic of $G$. imbricata Książkiewicz, and 3) densely spaced irregular incisions characteristic of $G$. obliterata Książkiewicz. According to Heer (1877), G. vermicularis is broader and possesses a deeper median furrow than $G$. comosa, and $G$. ramosa is broader and laterally branched.

\section{Ichnogenus Helminthopsis Heer, 1877}

\section{TYPE ICHNOSPECIES}

Helminthopsis hieroglyphica Wetzel and Bromley, 1996, by subsequent designation (Wetzel and Bromley, 1996:13).

\section{DIAGNOSIS}

Unbranched, irregularly winding or meandering, pre- or postdepositional horizontal burrows or trails that do not touch or cross themselves. Only one order of meandering may be prescnt. Burrow-fill massive (after Han and Pickerill, 1995).

\section{DISCUSSION}

Han and Pickerill (1995) and Wetzel and Bromley (1996) have addressed the taxonomic status of the 22 historically defined ichnospecies of Helminthopsis. Han and Pickerill (1995) concluded that only three, namely, H. abeli Ksiażkiewicz, H. hieroglyphica Wetzel and Bromley, and H. granulata Książkiewicz, are taxonomically valid and useful forms, and Wetzel and Bromley (1996) that $H$. abeli, $H$. hieroglyphica, and $H$. tenuis Książkiewicz are 
preferable. Despite these differences in opinion, the Georgian Bay material does not conflict, at the ichnospecific rank, with these varied interpretations.

\section{Helminthopsis hieroglyphica Wetzel and Bromley, 1996} Pl. 6, fig. 3

\section{MATERIAL}

One slab: ROM 50075, plus additional field occurrences.

\section{DIAGNOSIS}

Helminthopsis in which the windings, normally wide and low, comprise straight segments interspersed with irregularly sinuous and variably developed segments. The full course is commonly, though not exclusively, alternately winding and straight (after Książkiewicz, 1977; Han and Pickerill, 1995; Wetzel and Bromley, 1996).

\section{DESCRIPTION}

Specimens are preserved as smooth concave epireliefs and convex hyporeliefs, $1-4 \mathrm{~mm}$ in diameter and $35-180 \mathrm{~mm}$ in length. Burrows can display an elliptical cross-section. Individual traces never cross. Burrows display low and broad meanders along with straight segments up to $85 \mathrm{~mm}$ in length.

\section{REMARKS}

The presence of straight segments in association with an irregular winding pattern distinguishes these traces from other ichnospecies of Helminthopsis. Though traditionally this ichnospecies had Heer in Maillard, 1887, as its author, Wetzel and Bromley (1996) have recently proposed a new type.

\section{Ichnogenus Lingulichnus Hakes, 1976}

\section{TYPE ICHNOSPECIES}

Lingulichnus verticalis Hakes, 1976, by monotypy.

\section{DIAGNOSIS}

Vertical to slightly inclined, tubular burrows with elliptical transverse cross-section displaying two planes of symmetry (after Szmuc et al., 1976).

\section{DISCUSSION}

Lingulichnus was established by Hakes (1976) for sediment-filled tubes that possessed an elliptical cross-section and occurred perpendicular or inclined to bedding. At the same time, one ichnospecies, $L$. verticalis, was erected. Later the same year, Szmuc et al. (1976) erected Lingulichnites amygdalinus describing essentially identical traces, a fact recognized by Osgood (in Szmuc et al., 1977) when this ichnogenus was placed in synonymy with Lingulichnus, the latter being regarded as valid by publication priority. Several possibilities regarding the nature of the tracemaking organisms were discussed by Hakes (1976), who ultimately concluded that linguloid brachiopods were responsible, the presence of two planes of symmetry in both trace and tracemaker being cited as principal evidence. Bivalves were dismissed because they possess only one plane of symmetry, as were worms because of the unlikelihood that such organisms would be able to produce vertical burrows with elliptical cross-sections. cf. Lingulichnus verticalis Hakes, 1976

Pl. 6, fig. 2

\section{MATERIAL}

One specimen: ROM 17496 [1257HR] (partim), plus additional field occurrences.

\section{DIAGNOSIS}

Lingulichnus, commonly with concentrically packed walllining, parallel-sided or widest at the top, generally showing a narrower basal projection (burrow) of nearly circular cross-section (after Hakes, 1976; Szmuc et al., 1976).

\section{DESCRIPTION}

Specimens are preserved as rounded elliptical convex hyporeliefs with long axes 11-18 $\mathrm{mm}$ in length and short axes 5-9 $\mathrm{mm}$ in length. Sectioning revealed no disturbance of the overlying sediment other than the presence of a single specimen of Skolithos verticalis (Hall).

\section{REMARKS}

The absence of a completely preserved three-dimensional structure precludes definitive ichnogeneric assignment, yet their cross-sectional views accord with previously figured examples of Lingulichnus, and therefore are tentatively identified as such. Despite the lack of any vertical structure, the material can still be regarded as $\mathrm{cf}$. $L$. verticalis based on cross-section morphology. 


\section{TYPE ICUNOSPECIES}

Monocraterion tentaculatum Torell, 1870, by monotypy.

\section{DIAGNOSIS}

Funnels or stacked funnels oriented perpendicular to bedding and characterized by a central downward deflection of sedimentary laminac. Funnels may be perforated centrally by a tube that may continue down (after Crimes et al., 1977).

\section{DISCUSSION}

Monocraterion encompasses vertical burrows associated with funnel-shaped apertures (Torell, 1870). Comparisons have been made between this ichnogenus and several others, namely, Cylindrichnus Toots in Howard, Laevicyclus Quenstedt, Rosselia Dahmer, and Skolithos. Skolithos, which takes the form of simple vertical tubes, has commonly been regarded as a senior synonym of Monocraterion (see Ekdale et al., 1984). As the latter ichnogenus comprises a vertical tube capped by a funnel-like aperture that can easily be eroded away, the possibility exists that many examples of Skolithos may in fact represent eroded specimens of Monocraterion that have lost their capping funnel-shaped aperture. Crimes et al. (1977) and Fillion and Pickerill (1990b) have, however, discussed reasons for retaining both ichnotaxa; herein, we follow their recommendation.

In order to distinguish Monocraterion from Cylindrichnus, Laevicyclus, and Rosselia, specimens must be vertically sectioned (a course not always followed by several ichnologists, e.g., Badve and Ghare, 1980; Leszczyński and Seilacher, 1991), because all four ichnogenera display, in bedding-plane view, circular to slightly elliptical sets of concentric circles with, in some cases, a central mound corresponding to a vertical or oblique shaft. However, when specimens of these ichnotaxa are vertically sectioned, Monocraterion is found to comprise a vertical tube flaring at the aperture, taking a funnel-like form (Häntzschel, 1975). Alternatively, Cylindrichnus takes the form of subconical, weakly curved, circular to oval burrows, bearing concentrically layered exterior walls (Häntzschel, 1975). Laevicyclus comprises a central vertical tube whose aperture is surrounded by concentric circles, possibly produced by a circular sweeping action of extended tentacles (Osgood, 1970), and Rosselia takes the form of thin burrows, commonly oblique to bedding, that bear expanded openings filled with concentric layers of weathered matrix (Häntzschel, 1975).

To our knowledge, only four ichnospecies of Monocraterion have been cited in the literature, namely, $M$. clintonense (James), M. lesleyi Prime, M. rajnathi
Badve and Ghare, and M. tentaculatum. Of these, the first two appear to be recognized only by the age of the deposits in which they are found and $M$. rajnathi by the presence of a thin wall and a less crowded occurrence (Badve and Ghare, 1978). While no other ichnospecies of Monocraterion has been described as displaying a wall, the possibility exists that it reflects the nested cone structure characteristic of Monocraterion. Therefore, this ichnospecies is best regarded as a nomen dubium. Howell (1946:33) suggested, with respect to $M$. tentaculatum and $M$. clintonense, that the former's "burrows are so similar to our Silurian burrows that the two should perhaps be considered to be congenetic, in spite of the fact that the one is Cambrian age, the other Silurian." Use of the same "distinguishing criterion" is implied in the case of $M$. lesleyi, "believed to be of Early Ordovician age" (Howell, 1946:33). As age is not a valid ichnotaxobase under any circumstances, and as no additional distinguishing criteria have been given for these ichnotaxa, $M$. clintonense and $M$. lesleyi should best be considered junior synomyms of M. tentaculatum.

\section{cf. Monocraterion tentaculatum Torell, 1870 \\ Pl. 6, fig. 4}

\section{MATERIAL}

One specimen: ROM 50077, plus additional field occurrences.

\section{DIAGNOSIS}

Sub-cylindrical tube, perpendicular to bedding, typically straight, rarely slightly curved, ends upwards in a funnel. Tube unbranched, in many cases slightly tapering downwards. Funnel in transverse section circular or fairly irregular, in vertical section wide or narrow, straight-sided, cupor trumpet-shaped; varying in width and depth. The tube continues through the funnel in several instances, and sporadically ends upwards in a second funnel (after Fillion and Pickerill, 1990a).

\section{DESCRIPTION}

Specimens comprise round to slightly elliptical markings, $11-27 \mathrm{~mm}$ in diameter, preserved as concave hyporeliefs, though two specimens are preserved in concave epirelief. Markings are ornamented with internal concentric rings. In two specimens, circular mounds $6 \mathrm{~mm}$ wide are present in the centre of the specimen. In most cases, when vertically sectioned, specimens contained no distinct associated overlying or underlying structure, although one individual was associated with an underlying funnel-shaped structure revealed by disturbed bedding. 


\section{REMARKS}

Distinction from the similar ichnogenera Laevicyclus and Rosselia is based on the nature of associated vertical structure. As no such structure is associated with any of these specimens, they can be compared only with Monocraterion. Specimens preserved as concave hyporeliefs represent casts on the bases of sandstone beds of burrows originally situated in underlying mud deposits, this accounting for the lack of associated vertical structures. Of the two preserved as concave epireliefs, one is associated with an underlying, distinctly funnel-shaped structure revealed by disturbed bedding.

\section{Ichnogenus Monomorphichnus Crimes, 1970}

\section{TYPE ICHNOSPECIES}

Monomorphichnus bilinearis Crimes, 1970, by monotopy.

\section{DIAGNOSIS}

A series of straight or slightly sigmoidal, parallel or intersecting striae, isolated or grouped in sets, in places repeated laterally, and typically preserved in convex hyporelief (after Crimes, 1970).

\section{DISCUSSION}

Monomorphichnus was erected by Crimes (1970) to encompass traces produced by trilobites that raked the sediment surface while being carried by a current. Similarities between Monomorphicnus and Dimorphichnus Seilacher were noted by Crimes (1970:58), though the two ichnogenera differ in the former's lack of "blunt markings formed by the digging in of the limbs on one side." When initially erected, only one ichnospecies was recognized, namely, $M$. bilinearis, characterized by paired parallel striae, one more pronounced than the other (Fillion and Pickerill, 1990a). Subsequently, four additional ichnospecies have been described, namely, $M$. multilineatus Alpert, characterized by deeper central ridges; $M$. lineatus Crimes, Legg, Marcos and Arboleya, displaying single ridges; $M$. pectenensis Legg, characterized by the presence of striations between individual ridges; and $M$. intersectus Fillion and Pickerill, which exhibits intersecting dig marks. A fifth ichnospecies, $M$. cretacea Badve and Ghare, is better placed in $M$. lineatus, the former having been recognized as a distinct ichnospecies only on the basis of its geological age, an unacceptable ichnotaxobase.

\section{Monomorphichnus bilinearis Crimes, 1970}

Pl. 7, fig. 1

\section{MATERIAL}

One specimen: ROM 50078.

\section{DIAGNOSIS}

Monomorphichnus with paired parallel striae with one stria of each pair typically more prominent than the other (after Crimes, 1970).

\section{DESCRIPTION}

Specimen consists of four pairs of straight to slightly curved parallel ridges, $10-35 \mathrm{~mm}$ in length, preserved as convex hyporeliefs. Within each pair, one ridge is longer and slightly wider than the other, widths varying between $0.25 \mathrm{~mm}$ and $0.75 \mathrm{~mm} ; 2-3.5 \mathrm{~mm}$ separate each ridge within a pair, pairs being $9-10 \mathrm{~mm}$ apart. Sediment comprising ridges is coarser grained than the host rock, producing a condition in which several of the ridges are recognized solely by a difference in lithology, no vertical relief being present.

\section{REMARKS}

Monomorphichnus bilinearis is distinguished from other ichnospecies of Monomorphichnus through its possession of paired ridges, not seen in $M$. lineatus; its lack of striations between ridges characteristic of $M$. pectenensis; and its lack of deeper central ridges seen in M. multilineatus.

Monomorphicnus lineatus Crimes, Legg, Marcos and Arboleya, 1977

Pl. 5, fig. 4; Pl. 7, fig. 2

Monomorphichnus Kerr and Eyles, 1991, fig. 10a.

\section{MATERIAL}

One specimen: ROM 50079, plus additional field occurrences.

\section{DIAGNOSIS}

Monomorphichnus composed of parallel, isolated, straight to slightly sigmoidal striae, which may be repeated laterally (after Crimes et al., 1977).

\section{DESCRIPTION}

The material consists of groups of four to sixteen unpaired ridges preserved as convex hyporelicfs that are 4-79 $\mathrm{mm}$ in length and $0.2-1 \mathrm{~mm}$ in width. Distance between individual ridges is $1-9 \mathrm{~mm}$, complete sets being $24-30 \mathrm{~mm}$ in length by $4-86 \mathrm{~mm}$ in width. Most ridges are straight, though some may be slightly sinuous.

\section{REMARKS}

Monomorphichnus lineatus can be distinguished from $M$. bilinearis through the former's lack of paired ridges, and from $M$. multilineatus in that the latter possesses central ridges that are decper than the outer ridges. 
TYPE ICHNOSPECIES

Paleodictyon strozzii Meneghini, 1850, by monotypy.

\section{DIAGNOSIS}

Honcycomb-like network of four-to-eight-sided, commonly hexagonal, horizontal meshes, preserved typically in convex hyporelief, more rarely in concave epirelief. Meshes with or without vertical outlets, of variable size and shapc. Outline of entire systems rounded, or more typically hexagonal (after Pickerill, 1990).

\section{DISCLSSION}

See Stanley and Pickerill, 1993b, and Crimes and McCall, 1995.

\section{Paleodictyon isp. a}

Pl. 8, fig. 1

Paleodictyon isp. a Stanley and Pickerill, 1993b, figs. 2a-b.
MATERIAL

Two specimens: ROM 49424 and ROM 49624.

\section{DESCRIPTION AND REMARKS}

See Stanley and Pickerill, 1993 b.

?Paleodictyon isp. $\mathrm{b}$

Pl. 9, fig. 3

?Paleodictyon isp. b Stanley and Pickerill, 1993b, fig. 2c.

MATERIAL

One specimen: ROM 49625.

DESCRIPTION AND REMARKS

See Stanley and Pickerill, 1993 b.

\section{Ichnogenus Palaeophycus Hall, 1847}

\section{TYPE ICHNOSPECIES}

Palaeophycus tubularis Hall, 1847, by subsequent designation (Miller, 1889:130).

\section{DIAGNOSIS}

Straight to slightly curved to slightly undulose or flexuous, smooth or ornamented, typically lined, essentially cylindrical, predominantly horizontal structures interpreted as originally open burrows; burrow-fill typically massive, similar to host rock; where present, bifurcation is not systematic, nor does it result in swelling at the sites of branching (after Fillion and Pickerill, 1990a).

\section{DISCUSSION}

Palaeophycus was originally erected by Hall (1847) to include plants with terete, simple or branched, cylindrical or sub-cylindrical stems whose surfaces were nearly smooth, without transverse ridges, and apparently hollow (Hall, 1847). The original designation of the nomenclatural type of Palaeophycus has been a topic of debate. Pemberton and Frey (1982) shared Häntzschel's (1975) belief that Bassler (1915) designated $P$. tubularis as the type ichnospecies. However, Miller (1889:130) was in fact the first to make this designation (Fillion and Pickerill, 1990a). The diagnosis of Palaeophycus was twice emended by Fillion and Pickerill (1984b, 1990a), first to exclude systematic and non-systematic winding and/or meandering burrows and then to exclude systematically branching burrows as well as burrows in which there is swelling at the points of branching due to bifurcation. A detailed discussion of the distinction between Palaeophycus and the morphologically similar ichnogenus Planolites can be found in Pemberton and Frey (1982), Stanley and Pickerill (1994), and Keighley and Pickerill (1995).

\section{cf. Palaeophycus crenulatus Buckman, 1995}

Pl. 7, fig. 3

\section{MATERIAL}

One specimen: ROM 50058, plus additional field occurrences.

\section{DIAGNOSIS}

Annulate Palaeophycus with annulations on a millimetre scale (after Buckman, 1995).

\section{DESCRIPTION}

Specimens preserved as straight to slightly curved, unbranched convex epireliefs and hyporeliefs, 5-6 mm wide and 69-156 mm long with an elliptical to circular cross-section. Surfaces are covered by annulations $0.9-2$ $\mathrm{mm}$ wide and $\mathrm{l}-2 \mathrm{~mm}$ apart, displaying densitics of two to ten annulations per $\mathrm{cm}$. Burrow-fill is similar to the host rock.

\section{REMARKS}

$P$. crenulatus was recently formulated and described by Buckman (1995), who thereby alleviated the impractical 
nomenclatural problems involved with the ichnotaxa $P$. annulatus and $P$. serratus, described respectively by Badve (1987) and McCann (1993). Although no linings are visible on the Georgian Bay material, we believe this may be a function of weathering (cf. Frey and Howard, 1985). Additionally, Buckman (1995) failed to resolve the overall nomenclatural difficulties with respect to annulate ichnotaxa and offered a precise limit, based solely on his Irish material, on the annulation density, an ichnotaxobase that in our experience can be varied. We therefore only tentatively assign the material to $P$. crenulatus.

\section{Palaeophycus heberti (de Saporta, 1872) \\ Pl. 8, fig. 2}

MATERIAL

One specimen: ROM 50080.

\section{DIAGNOSIS}

Unornamented, thickly lined Palaeophycus (after Pemberton and Frey, 1982).

\section{DESCRIPTION}

Specimen is preserved as a slightly curved, unbranched, thickly lined, smooth, concave/convex epirelief maintaining a uniform total width of $2.8 \mathrm{~mm}$. The central tube, where preserved, is oval in cross-section and $1.3 \mathrm{~mm}$ in width by $1 \mathrm{~mm}$ in height. Complete specimen, as preserved, is $65 \mathrm{~mm}$ long. Both the fill and the lining are massive and identical to the host sediment.

\section{REMARKS}

Palaeophycus heberti can be distinguished from P. tubularis by the presence of a thick lining on the former. It is set apart from all remaining ichnospecies of Palaeophycus by its lack of any external ornamentation.

\section{Palaeophycus striatus Hall, 1852}

Pl. 9, fig. 1

Kerr and Eyles, 1991, fig. 10h (partim).

\section{MATERIAL}

One specimen: ROM 50081, plus additional field occurrences.

\section{DIAGNOSIS}

Thinly lined Palaeophycus, sculpted by continuous, parallel, longitudinal striae (after Pemberton and Frey, 1982).

\section{DESCRIPTION}

Specimens are preserved as either concave or convex epirelicfs. All are straight to slightly curved. Dimensions vary from $3 \mathrm{~mm}$ to $9 \mathrm{~mm}$ in width and $32 \mathrm{~mm}$ to $45 \mathrm{~mm}$ in length. Parallel striae with $0.5-1.5 \mathrm{~mm}$ between crests run the entire length of each of the specimens, with reliefs varying from fine $(\approx 0.1 \mathrm{~mm})$ to very coarse $(\approx 0.75 \mathrm{~mm})$. Where burrow-fill is present, it is identical to the host rock.

\section{REMARKS}

The presence of striations uninterrupted along their length distinguishes these specimens from $P$. alternatus (Pemberton and Frey, 1982).

\section{Palaeophycus tubularis Hall, 1847}

Pl. 8, fig. 3

Palaeophycus sp. indet. Fritz, 1925:28-29, pl. 3, fig. 2.

Palaeophycus virgatus Fritz, 1925:32, pl. 3, fig. 3.

Unnamed burrow-Kerr and Eyles, 1991, fig. 10h (partim).

\section{MATERIAL}

Two suites in ROM collections: ROM 17494 [1255HR] (partim) (containing two specimens) and ROM 17495 [1256HR], plus numerous field occurrences.

\section{DIAGNOSIS}

Smooth, unornamented burrows of variable diameter, thinly but distinctly lined (after Pemberton and Frey, 1982).

\section{DESCRIPTION}

Specimens are preserved in convex hyporelief or full relief, with both displaying elliptical cross-sections. Traces range in diameter from $1 \mathrm{~cm}$ to $3 \mathrm{~cm}$. Surfaces are generally smooth, though faint longitudinal and transverse striations are present in areas of some specimens. No evidence of lining is present on any specimen. Burrow collapse is present in one example, revealed by changes in burrow cross-section eccentricity, and by the presence of a wrinkled appearance in places. Traces are straight to slightly sinuous. Apparent branching produced by burrow interpenetration is present in two specimens. Burrow-fill is of similar lithology to the host rock in all cases.

\section{REMARKS}

The thin lining, one of the diagnostic characteristics of Palaeophycus tubularis, was not observed in any of the specimens, probably because such a thin lining is easily eroded (Howard and Frey, 1984; Frey and Howard, 1985). However, the presence of burrow collapse, the lack of surface ornament, and the similar grain size of the fill and host rock all support assignment of the present material to this ichnospecies. Of the three samples originally catalogued as ROM 17494 [1255HR] to represent Palacophycus virgatus, only two are considered by us as belonging to $P$. rubularis. The third, a trace preserved as a concavo-convex full 
relief bearing striations on the convex surface, is believed to be Trichophycus venosus Miller and Dyer. One additional specimen (ROM 17495 [1256HR]), originally described by Fritz (1925) as Palaeophycus sp. indet., is in fact assignable to $P$. mbularis.
Palaeophycus virgatus, to which the ROM matcrial was originally assigned by Fritz (1925), was described by Alpert (1975) as Planolites virgatus (Hall, 1847). Subsequently, Pemberton and Frey (1982) placed this ichnospecies in synonymy with Palaeophycus tubularis.

\section{Ichnogenus Phycodes Richter, 1850}

\section{TYPE ICHNOSPECIES}

Phycodes circinatus Richter, 1853:30, by subsequent monotypy.

\section{DIAGNOSIS}

Horizontal bundled burrows preserved outwardly as convex hyporeliefs. Overall pattern may be reniform, fasciculate, flabellate, broom-like, ungulate, linear, falcate, or circular. Some forms consist of a few main branches showing a spreite-like structure that gives rise distally to numerous free branches. In other forms the spreiten are lacking and branching tends to be secund or more random. Individual branches are terete and finely annulate or smooth (after Osgood, 1970).

\section{DISCUSSION}

Several ichnogenera have been placed in synonymy with Phycodes, though some of these assignations have been questioned. Seilacher (1955) suggested that Arthrophycus Hall, discussed in some detail by Sarle (1906), was a junior synonym of Phycodes, but this was refuted by Osgood (1970) on the grounds that the former was larger, displayed bilobate branching up to $1 \mathrm{~cm}$ in diameter, and was transversely articulated. Indeed, most ichnologists still regard Phycodes and Arthrophycus as separate and distinctive. Hall's (1852) Buthotrephis palmata was also considered synonymous with Phycodes by Seilacher (1955), but this was also not supported by Osgood (1970) because although $B$. palmata was unlike others in that ichnogenus, the branches were smoother, larger, and displayed a different branching pattern to that seen in Phycodes. However, Osgood (1970) did not take into consideration that B. palmata was based on discordant types, some specimens displaying branching from a single point, as seen in Phycodes, while others displayed branching at different distances from the base, as seen in Chondrites (Fillion and Pickerill, 1990b). The assignment of Licrophycus Billings as a junior synonym of Phycodes by Osgood (1970) has stood unchallenged. A detailed discussion on the ichnospecies of Phycodes is given in Han and Pickerill (1994a).

\section{Phycodes flabellus (Miller and Dyer, 1878a)}

Pl. 11, fig. 2

Licrophycus flabellum Fritz, 1925:27-28, pl. 3, fig. 1.

\section{MATERIAL}

One specimen in ROM collections: ROM 17496 [1257HR] (partim), plus numerous field specimens.

\section{DIAGNOSIS}

Bundled burrows generally arranged in a flabellate pattern. Individual branches cylindrical and annulate. Sectioning reveals no evidence of spreite-like structure or faecal material (after Osgood, 1970).

\section{DESCRIPTION}

Flabellate, horizontally bundled burrow systems preserved in convex hyporelief. Comprised of one smooth central burrow, approximately $3 \mathrm{~mm}$ wide and up to $44 \mathrm{~mm}$ in length, from which branch narrower burrows (approximately $1 \mathrm{~mm}$ wide) that are, for the most part, distinctly annulated, with annulations at intervals of approximately $0.5 \mathrm{~mm}$, though some portions are smooth. In several instances, truncation of earlier sets of these narrower burrows by later sets can be observed, suggesting the presence of two or three individuals. Annulations found on each bundle of burrows are concurrent. Extent of relief attains a maximum of $3 \mathrm{~mm}$, though there is little evidence of vertical extent on the sides of the specimen, only one or two poorly preserved burrow cross-sections being observable.

\section{REMARKS}

In Fritz's (1925) original examination of the Georgian Bay Formation ichnofauna, ROM 17496 [1257HR] was described as Licrophycus flabellum, an assignment with which, given the state of ichnology in 1925, the present authors agree. However, given that Licrophycus has since been placed in synonymy with Phycodes (Osgood, 1970), we regard the ROM material as Phycodes flabellus.

The limited material available did not permit sectioning to determine the three-dimensional structure. Sectioning of Cincinnatian representatives of this ichnospecies by Osgood (1970), however, revealed that spreite-like structures were generally absent. Instead, the presence of an area of disturbed bedding grading into the host rock seemed to Osgood (1970) to have been produced by an organism that mined the sediment by displacing rather than removing it. This displacement did not produce a burrow upon whose floor sediment could be compacted due to upward movement to produce a spreite. 
Phycodes palmatus (Hall, 1852)

Pl. 10, fig. 3

MATERIAL

One specimen: ROM 50082, plus an additional field occurrence.

\section{DIAGNOSIS}

Phycodes exhibiting a few thick and rounded branches, branching horizontally in a palmate or digitate form from nearly the same point (after Hall, 1852).

\section{DESCRIPTION}

Specimens preserved as convex hypichnial, striate, straight to slightly curving horizontal burrows, $6-14 \mathrm{~mm}$ in diameter, 15-49 mm in length, and displaying up to two levels of branching. Angles between the outer first-order branches vary from $80^{\circ}$ to $100^{\circ}$, while second-order branches display angles from $35^{\circ}$ to $45^{\circ}$. The presence of a spreite can be inferred from the fact that second-order branches can be seen to originate at different levels from their associated first-order burrow (cf. Pickerill and Peel, 1990). Maximum widths of individual specimens vary from $44 \mathrm{~mm}$ to $50 \mathrm{~mm}$.

\section{REMARKS}

Phycodes palmatus was originally erected as an ichnospecies of Buthotrephis, an ichnogenus that is for the most part a junior synonym of Chondrites. Fillion and Pickerill (1990b) noted that, upon examination of Hall's (1852) original figures, B. palmata was based on discordant material in that three different types of morphologies were present, one comparable to Phycodes, another to Chondrites, and the third was of doubtful affinity. They suggested (Fillion and Pickerill, 1990b) that material comparable to $P$ hycodes be regarded as $P$. palmatus. However, Seilacher (1955) had previously described several specimens as $P$. palmatus from the Lower Cambrian of Pakistan that displayed a different "Bauplan." To resolve this conflict, Fillion and Pickerill (1990a) erected P. wabanensis to include Seilacher's (1955) material in addition to similar examples from the Lower Ordovician of Bell Island, eastern Newfoundland. The present material is placed within $P$. palmatus through its possession of thick and rounded digitate branches characteristic of this ichnospecies. The presence of longitudinal striations, however, is an unusual morphological variant.

\section{Ichnogenus Planolites Nicholson, 1873}

TYPE ICHNOSPECIES

Planolites vulgaris Nicholson and Hinde, 1874, by subsequent designation (Miller, 1889:520).

\section{DIAGNOSIS}

Unlined, rarely branched, straight to tortuous, smooth to irregularly walled or ornamented, horizontal to slightly inclined burrows, circular to elliptical in cross-section, of variable dimensions and configurations. Burrow-fill biogenic, essentially massive, differing from host rock (after Pemberton and Frey, 1982).

\section{DISCUSSION}

See Stanley and Pickerill, 1994; Keighley and Pickerill, 1995.

\section{Planolites annularius Walcott, 1890}

Pl. 6, fig. 1

Planolites annularius Pickerill, 1994, fig. 1.3 (partim).

\section{MATERIAL}

One specimen: ROM 50073 (partim), plus numerous field occurrences.

\section{DIAGNOSIS}

Distinctly annulatc Planolites (aftcr Pcmberton and Frey, 1982).

\section{DESCRIPTION}

Specimens preserved as horizontal, straight to curved, unbranched, unlined, cylindrical burrows, $2-4 \mathrm{~mm}$ wide by $18-35 \mathrm{~mm}$ long, preserved in convex epirelief. Surfaces are covered by annulations $1 \mathrm{~mm}$ thick by $2.2-4.2 \mathrm{~mm}$ wide with up to $1 \mathrm{~mm}$ spacing. Burrows are circular to elliptical in cross-section. Lithology of burrow-fill is slightly more coarsely grained than the host rock. Some examples grade into Planolites beverleyensis; in such cases, annulations are seen to gradually change from encircling the entire burrow to appearing as lateral swellings on the sides of an otherwise smooth burrow.

\section{REMARKS}

Planolites annularius can be distinguished from other ichnospecies of Planolites through its possession of welldeveloped annulations, but with no accompanying external ornamentation. The majority of the examples of $P$. annularius occur as compound specimens in association with the ichnotaxa P. beverleyensis and Gyrochorte comosa. Such compound specimens offer insight into the variations in bchaviour exhibitcd by single individual organisms over short periods of time, and, in the examples herein, clearly show that a single individual can be engaged in three distinct bchaviourial activitics along a single course, involving the production of annulate, smooth, and plaited burrows respectively. 
Planolites beverleyensis (Billings, 1862)

Pl. 6, fig. 1

Planolites beverleyensis Pickcrill, 1994, fig. 1.3 (partim).

\section{MATERIAL}

One specimen: ROM 50073 (partim), plus numerous ficld occurrences.

\section{DLAGNOSIS}

Relatively large, smooth, straight to gently curved or undulose Planolites (after Pemberton and Frey, 1982).

\section{DESCRIPTION}

Material preserved in convex epirelief as smooth, horizontal, straight to curved, unbranched cylindrical burrows, $2-5 \mathrm{~mm}$ in width by up to $40 \mathrm{~cm}$ in length. Lithology of burrow-fill is slightly more coarsely grained than the host rock. Transverse cross-sections are circular to elliptical. In several cases, examples grade laterally into specimens of both P. annularius and Gyrochorte comosa.

\section{REMARKS}

Planolites beverleyensis can be distinguished from P. montanus through the latter's more contorted course. The remaining ichnospecies of Planolites bear external omamentation, thereby separating them from $P$. beverleyensis.

Planolites constriannulatus Stanley and Pickerill, 1994 Pl. 9, fig. 2

Planolites constriannulatus Stanley and Pickerill, 1994, figs. 2, 3a-e.

MATERIAL

Twelve specimens on four slabs: ROM 49764 (holotype), ROM 49765, ROM 49766a-d, and ROM 49767a-f (paratypes).

\section{DIAGNOSIS}

Planolites characterized by both longitudinal striations and transverse annulations superimposed in the same specimen (after Stanley and Pickerill, 1994).

DESCRIPTION AND REMARKS

See Stanley and Pickerill, 1994.

\section{Ichnogenus Protovirgularia McCoy, 1850}

\section{TYPE ICHNOSPECIES}

Protovirgularia dichotoma McCoy, 1850, by monotypy.

\section{DIAGNOSIS}

Plaited, unbranched, keel-like trail, mostly straight or slightly curved, more rarely sinuous, consisting of a median line (ridge or furrow) with lateral chevron markings opening in the direction of movement of the producing organism (modified after Han and Pickerill, 1994b; Seilacher and Seilacher, 1994).

\section{DISCUSSION}

The nomenclatural history and detailed taxonomic considerations of Protovirgularia have recently been discussed by Han and Pickerill (1994c) and Seilacher and Seilacher (1994), and there is little need of additional discussion. Seilacher and Seilacher (1994) convincingly demonstrated that the ichnotaxon is produced by bivalves burrowing in, or crawling on, soft substrates.

\section{Protovirgularia rugosa (Miller and Dyer, 1878a)}

Pl. 10, fig. 1

\section{MATERIAL}

Two specimens: ROM 49767 and ROM 50091 (partim).

\section{DIAGNOSIS}

Cubichnial version of Protovirgularia, recognized by a chevroned escape burrow leading away from a smooth Lockeia-like resting burrow. Chevron marks very strong (after Seilacher and Seilacher, 1994).

\section{DESCRIPTION}

Specimens preserved as convex epireliefs $18-33 \mathrm{~mm}$ long by $2-8 \mathrm{~mm}$ wide and bearing five to fourteen pairs of obliquely directed, parallel lateral ridges, $0.5 \mathrm{~mm}$ thick, emanating from a central ridge $1 \mathrm{~mm}$ wide running the length of the trace. These lateral ridges originate from several different levels and may or may not bifurcate at their distal extremities. Two specimens bear a characteristic featureless, Lockeia-like ovoid mass, $6-9 \mathrm{~mm}$ long by $2-6$ $\mathrm{mm}$ wide, at one end. A marked tapering is present at the opposing end of the trace, where preserved. Relief varies from $0.5 \mathrm{~mm}$ to $2 \mathrm{~mm}$.

\section{REMARKS}

Seilacher and Seilacher (1994) considered Walcottia rugosa Miller and Dyer a junior synonym of Protovirgularia McCoy, designating the type of their newly formulated $P$. rugosa Seilacher and Seilacher, 1994, as the holotype of W. rugosa, as documented by Miller and Dyer (1878a). Regrettably, Seilacher and Seilacher (1994) did not con- 
sider W. cookana Miller and Dyer, W. sulcata James, $W$. devilsdingli Benton and Gray, and W. imbricata (Hakes), and the taxonomic status of these forms remains equivocal (see also Rindsberg, 1994). Nevertheless, we are in general agreement with the taxonomic decisions made by Seilacher and Seilacher (1994), and of the four ichnospecies of Protovirgularia recognized by them we regard the Georgian Bay material as best identified as $P$. rugosa. Interestingly, Seilacher and Seilacher (1994) noted that $P$. rugosa is always found at the bases of sandy tempestites, an observation that accords well with the material described herein.

\section{?Protovirgularia isp.}

Pl. 10, fig. 2

\section{MATERIAL}

One specimen: ROM 50091 (partim), plus numerous field occurrences.

\section{DESCRIPTION}

Specimens are preserved as convex epireliefs 6-24 mm long by $8-24 \mathrm{~mm}$ wide. Though poorly preserved, a central ridge $0.3-1.0 \mathrm{~mm}$ wide and bearing five to seven oblique lateral ridges of comparable width is discemible. Each lateral ridge may have up to four first-order branches, or none, along its length. The larger example bears a featureless circular mass similar to those present on examples of $P$. rugosa described above.

\section{REMARKS}

The material is only tentatively included within Protovirgularia because of its poor preservation. Notably, of the four ichnospecies recognized by Seilacher and Seilacher (1994), Protovirgularia longespicata (de Stefani) is the only ichnospecies to develop palmate systems, a result of repeated probings by the producing bivalve.

\section{Ichnogenus Rusophycus Hall, 1852}

\section{TYPE ICHNOSPECIES}

Rusophycus clavatus Hall, 1852, by subsequent designation of Miller (1889:138).

\section{DIAGNOSIS}

Shallow to deep, short, horizontal, bilobate burrows preserved in convex hyporelief. Lobes are parallel or merge posteriorly and may be smooth or exhibit transverse to oblique scratch marks in various arrangements, typically directed anteriorly. Coxal, exopodal, spinal, cephalic, and pygidial markings may be present (after Fillion and Pickerill, 1990a).

\section{DISCUSSION}

Erected by Hall in 1852 as a genus of plants "consisting of simple or branched stems, which are transversely rugose or wrinkled" (Hall, 1852:23), Rusophycus has been the subject of nomenclatural confusion. Included in d'Orbigny's (1842) original description of the ichnogenus Cruziana was C. rugosa, whose dimensions and diagnosis fall within the current concept of Rusophycus. This prompted several authors to place all rusophyciform traces within the ichnogenus Cruziana (James, 1885; Seilacher, 1970, 1991), as "the valid name of a taxon is the oldest available name applied to it" (ICZN, 1985:47, Art. 23a). Such a scheme, however, does not permit distinction between cubichnial and repichnial forms at the ichnogeneric level, and as a result most authors now prefer to retain both Rusophycus and Cruziana as separate forms.

\section{Rusophycus cryptolithi Osgood, 1970}

Pl. 11, fig. 4

\section{MATERIAL}

One specimen: ROM 49427.

\section{DIAGNOSIS}

Small, ovoid, button-like Rusophycus. The striated lobes are subdivided into a coarser outer zone and a cordate, more finely striated, inner zone. Imprints of genal spines are commonly present. This ichnospecies differs from others within the ichnogenus by possessing a width which is equal to or slightly greater than the length (after Osgood, 1970).

\section{DESCRIPTION}

Specimen is preserved as a convex hyporelief measuring 7 $\mathrm{mm}$ in length by $8 \mathrm{~mm}$ in width. Two smooth lobes, separated by a median furrow running the full length of the trace, are framed on either side by l-mm wide impressions of the genal spines. These impressions bear step-like interruptions suggestive of interrupted forward motion.

\section{REMARKS}

Rusophycus cryptolithi can be distinguished from other forms of Rusophycus by its button-like shape whose width is gencrally cqual to or greater than its length. The characteristic ovoid shape and the presence of genal spine imprints suggest that the trilobite Cryptolithus might be a possible producer of the trace (cf. Osgood, 1970). 
Rusophycus osgoodii n. isp.

PI. 12. figs. $1-4$

TYPE. MATERIAL

Six specimens on four slabs: ROM 49882 (holotype) and ROM 49883-49885 (paratypes).

\section{ETYMOLOGY}

Named after the late Richard G. Osgood, Jr., in recognition of his contributions to Cincinnatian ichnology.

\section{DIAGNOSIS}

Oval Rusophycus bearing endopodal scratch marks running the complete width. Scratchings are coarser and more deeply impressed towards the outer margins, forming lobes. These lobes are more pronounced in shallower specimens, flaring anteriorly. Fewer and finer scratchings are present in the flat region between lobes.

\section{DESCRIPTION}

Specimens preserved as convex hyporeliefs on the soles of grey, fine-grained calcareous sandstone beds. Individuals take the form of oval resting traces, $20-38 \mathrm{~mm}$ in length by 16-29 $\mathrm{mm}$ in width, bearing endopodal scratch marks $0.25-2 \mathrm{~mm}$ thick and running the complete width of specimens. Length-to-width ratios are between 1:2 and 1:5. Scratchings, numbering between six and twelve per lobe, are coarser and more deeply impressed towards the outer margins of the traces. In less deeply impressed specimens, this results in the traces taking the form of paired, transversely striated lobes, $5 \mathrm{~mm}$ wide, which flare anteriorly. Fewer and finer scratchings are displayed in the flat region between these lobes.

\section{REMARKS}

The presence of lobes bearing deeply impressed transverse endopodal scratchings associated with less deeply impressed endopodal scratchings in a central region between these lobes is unlike any morphology exhibited by previously described ichnospecies of Rusophycus. Previously recognized ichnospecies of Rusophycus that display bordering lobes, unlike $R$. osgoodii, typically bear longitudinal exopodal scratchings with clear endopodal scratchings in the central region between these lobes (e.g., $R$. carleyi (James), $R$. dilatata Seilacher, and $R$. morgati Baldwin).

\author{
Rusophycus polonicus Orlowski, Radwański and \\ Roniewicz, 1970 \\ Pl. 11, fig. 3
}

\section{MATERIAL}

Two specimens: ROM 49428 (plaster cast) and ROM 49429.

\section{DIAGNOSIS}

Oval resting traces with about 12 pairs of coxal impressions between decply impressed endopodal lobes on which the transverse or slightly retroverse markings are often indistinct. Pleural and genal spine impressions may occur (after Seilacher, 1970).

\section{DESCRIPTION}

Spccimens are preserved as oval convex hyporeliefs, $87-200 \mathrm{~mm}$ long by $70-115 \mathrm{~mm}$ wide. The traces are comprised of a pair of featureless endopodal lobes, each 14-24 mm wide, which frame a central area covered by 10 pairs of coxal impressions, each pair taking the form of a matching $\mathrm{S}$ and $\mathrm{Z}$ shape. On ROM 49428, the endopodal lobes extend towards the posterior, $24 \mathrm{~mm}$ beyond the central zone of coxal impressions.

\section{REMARKS}

Rusophycus polonicus was first described independently by Orlowski, Radwański, and Roniewicz (1970:356) and Seilacher $(1970: 473)$ in two separate contributions in Crimes and Harper, eds. (1970). As a result, the question of who should be considered as the original author(s) of the ichnospecies arises. Two possible approaches ultimately yield the same result. If one considers Orlowski, Radwański, and Roniewicz as having priority in accordance with the Code (ICZN, 1985, Art. 24a) in that their use of the ichnotaxon appears 117 pages earlier in the volume than that of Seilacher, then clearly they should be considered the authors. Additionally, however, Seilacher (1970) listed material figured by Radwański and Roniewicz (1963) both as the type specimens and the only forms in his synonymy of this ichnospecies, which further suggests that Orlowski, Radwański, and Roniewicz be regarded as the authors of the ichnospecies (see also Orlowski, 1992).

Rusophycus polonicus can be distinguished from other morphologically similar forms of Rusophycus through the absence of transverse or slightly retroverse markings on the endopodal lobes characteristic of Rusophycus carleyi and the lack of longitudinal markings on the same structure that are characteristic of Rusophycus dilatata. Seilacher (1970) used the informal term "Carleyi Group" to encompass all ichnospecies of Rusophycus bearing distinct coxal markings between deep endopodal lobes, thereby grouping $R$. carleyi, $R$. dilitata, and $R$. polonicus. Both Osgood (1970) and Seilacher (1970) have suggested that $R$. carleyi was produced by the burrowing activities of the trilobite Isotelus. 


\section{Rusophycus pudicus Hall, 1852}

Pl. 11, fig. 1

\section{MATERIAL}

Four specimens: ROM 17493 [1254HR] and ROM 50084-50086, plus additional field occurrences.

\section{DIAGNOSIS}

Shallow Rusophycus with a poorly to moderately developed median furrow extending the entire length of the trace, dividing it into two lobes which bear imbricate or unevenly concentrated, weakly developed, evenly spaced scratchings forming a very obtuse $\mathrm{V}$-angle. Length-towidth ratios vary between $1: 5$ and $1: 8$, width gradually tapering posteriorly. Impressions of cephalic and thoracic doublures and thoracic pleurae may be seen (after Osgood, 1970; Osgood and Drennen, 1975).

\section{DESCRIPTION}

Trilobite cubichnia preserved as bilobed elliptical convex hyporeliefs, the median furrow extending the entire length of the trace, width tapering posteriorly. Each lobe bears striae varying in width from $0.25 \mathrm{~mm}$ to $1 \mathrm{~mm}$, no mark- ings being seen on the nearly vertical sides of the trace. Lengths range from $13 \mathrm{~mm}$ to $23 \mathrm{~mm}$ while width varies from $10 \mathrm{~mm}$ to $14 \mathrm{~mm}$. Depth of the traces gradually decreases towards each end from a maximum near midlength.

\section{REMARKS}

Fritz (1925) made no attempt at ichnospecific assignment of rusophyciform burrows despite the availability of a well-preserved specimen (ROM 17493 [1254HR]). Reexamination of this specimen has led to its assignment to $R$. pudicus. One organism believed to have produced at least some examples of this ichnospecies is the trilobite Flexicalymene meeki, as its size and shape correspond to that of $R$. pudicus, and impressions of the cephalic doublure and thoracic pleurae are occasionally observed (Osgood, 1970). The occurrence of three specimens of $F$. meeki in direct association with this trace supports this belief (Osgood, 1970), though the possibility of these being chance occurrences should be borne in mind, and all examples of $R$. pudicus should not necessarily be equated with this particular trilobite species.

\section{Ichnogenus Skolithos Haldeman, 1840}

\section{TYPE ICHNOSPECIES}

Fucoides? linearis Haldeman, 1840, by monotypy.

\section{DIAGNOSIS}

Unbranched, vertical or steeply inclined, cylindrical or sub-cylindrical, lined or unlined burrows. Walls distinct or indistinct, smooth or rough, possibly annulate; burrow-fill massive; burrow diameter may vary slightly along its length (after Alpert, 1974).

\section{DISCUSSION}

Skolithos received an in-depth systematic review by Alpert (1974), resulting in the placement of several ichnogenera such as Sabellarifex Richter, Tigillites Rouault, and Stipsellus Howell within this ichnogenus. Alpert (1974) recognized five ichnospecies, namely, Skolithos annulatus (Howell), S. ingens Howell, S. linearis Haldeman, S. magnus Howell, and $S$. verticalis (Hall). This scheme is regarded by most ichnologists as adequate but in need of further attention, particularly with respect to examination of type specimens (Fillion and Pickerill, 1990a). One of the principal areas of weakness involves the three ichnospecies $S$. linearis, $S$. verticalis, and $S$. magnus, because their respective diagnoses reveal that they are essentially identical, ambiguous diameter ranges being the only distinguishing criterion. That for $S$. linearis, stated as 3-7 $\mathrm{mm}$, commonly up to $12 \mathrm{~mm}$, overlaps at the lower end with $S$. verticalis, with a diameter range of $1-4 \mathrm{~mm}$, and at the upper end with S. magnus, with a stated range of 6-12 $\mathrm{mm}$. This produces a problematic situation whereby a cylindrical, straight, vertical, indistinctly walled burrow, $10 \mathrm{~mm}$ in diameter, could be regarded as either S. linearis or S. magnus. In the same way, a cylindrical, straight, vertical burrow, $3.5 \mathrm{~mm}$ in diameter, could be regarded as either $S$. linearis or $S$. verticalis. Differing lengths were given for each of these latter ichnospecies by Alpert (1974), up to a metre and $2-15 \mathrm{~cm}$ respectively, though this criterion also does not adequately distinguish the two. Indeed, the usefulness of length as a diagnostic feature is questionable given that this characteristic is so dependent on preservation, the observed length in many cases bearing little rclation to the original length at the time the trace was produced.

One possible solution is to eliminate the overlapping nature of the diameter ranges for these ichnospecies. However, one could still argue that the three simply rcpresent a gradational change within a single ichnospecies.

Skolithos is generally believed to represent the feeding burrows of annelids or phoronids.

\section{Skolithos magnus Howell, 1944}

Pl. 13, fig. 1

\section{MATERIAL}

One specimen: ROM 50087, plus additional field occurrences. 


\section{DIAGNOSIS}

Skolithos that may curve slightly. Diameter 6-12 $\mathrm{mm}$. Burrow-wall indistinct, somewhat irregular (after Alpert, 1974).

\section{DESCRIPTION}

Specimens preserved in convex hyporelief, epirelief, or endorelief, with a circular to subcircular cross-section and following a straight to undulatory course. Diameters range from $8 \mathrm{~mm}$ to $11 \mathrm{~mm}$. One convex epirelief is surrounded by concentric rings. Burrow-fill is massive, with a grain size similar to the host rock. Previously existing laminae are cut with little evidence of downward deflection. Wall lining is absent in all specimens.

\section{REMARKS}

The specimens are assigned to this ichnospecies primarily on the basis that their diameter falls within the $6-12 \mathrm{~mm}$ range of $S$. magnus, other ichnospecies being smaller. The diameter of ROM 50087 must be regarded as a minimum. Since this specimen was discovered accidentally during vertical sectioning, no surface expression being present, it was impossible to determine whether the observed section represents the maximum diameter. Another specimen was found closely associated with specimens of Trichophycus lanosus, the producer of this trace conceivably having used the pre-existing Skolithos traces to access deeper sediments.
Skolithos verticalis (Hall, 1843)

Pl. 13, fig. 2

\section{MATERIAL}

One specimen: ROM 50088, plus numerous field occurrences.

\section{DIAGNOSIS}

Cylindrical to prismatic (where in contact), straight to curved, vertical to inclined Skolithos. Diameter $1-4 \mathrm{~mm}$, length $2-15 \mathrm{~cm}$. Burrow-wall smooth, rarely corrugated (after Alpert, 1974).

\section{DESCRIPTION}

Specimens preserved as unbranched, cylindrical, slightly curved, vertical burrows, $3.5-4 \mathrm{~mm}$ in diameter and $2.5-3$ $\mathrm{cm}$ in length. Some downward deflection of lamination seen. Fill is of same grain size and lithology as host rock, no evidence of internal structure being present. Surficial expression of tube opening very faint.

\section{REMARKS}

Both specimens are assigned to $S$. verticalis primarily on the basis of diameter and curved habit, $S$. linearis typically being straight. Given that the burrows are difficult to detect in horizontal section, both specimens having been found fortuitously during vertical slabbing, the possibility that the traces are one of a pair of vertical tubes belonging to Arenicolites must be considered.

\section{Ichnogenus Trichophycus Miller and Dyer, 1878a}

\section{TYPE ICHNOSPECIES}

Trichophycus lanosus Miller and Dyer, 1878a, by monotypy.

\section{DIAGNOSIS}

Cylindrical, straight to gently curved, horizontal burrows whose concave ventral surface is covered by fine striae which may radiate posterolaterally from the midline. Preserved in endorelief, convex hyporelief, or, more rarely, concave epirelief. May be seen to branch vertically. Irregularly spaced transverse constrictions may also be present. Groups of parallel, discontinuous, longitudinal ridges may be seen on the concave or flat, rarely convex, straight to gently arcuate dorsal surface. Lateral surfaces may possess up to seven finely striated continuous parallel ridges. Retrusive spreite are typically seen in burrow-fill. In lined specimens, passive, laminated fill is seen, though lining is rare. Burrows terminate abruptly in an arcuate fashion (after Fillion and Pickerill, 1990a).

\section{DISCUSSION}

Trichophycus was established by Miller and Dyer (1878a) as a genus of plants consisting of "simple branches or stems having diagonal or longitudinal markings, as if made by the folding down of hair-like filaments" (Miller and Dyer, 1878a:24-25). At the time, only one species was proposed, Trichophycus lanosus, described as a "plant consisting of [a] round, flexuous stem, having an enlargement or spheroidal swelling at one end, and being covered with diagonal and longitudinal lines" (Miller and Dyer, 1878a:25). Subsequently, Miller and Dyer (1878b) formulated $T$. sulcatus and the following year Miller (1879) proposed $T$. venosus.

James (1884) suggested that $T$. sulcatus and $T$. venosus were the products of water drainage, as they bore a strong resemblance to "rill marks" described by Dawson (in James, 1884). T. lanosus was later acknowledged by James (1885) to be a burrow rather than a plant, the diagonal and longitudinal lines resembling folded-down, hair-like filaments referred to in the original description, probably resulting from the action of burrow formation (James, 1885). Additionally, $T$. lanosus was viewed as synonymous with Blastophycus, a genus of "plant" proposed by Miller 
and Dyer (1878a) and probably representing an early stage in the formation of $T$. lanosus (James, 1885). In 1891, James placed Saccophycus intortus James in synonymy with Blastophycus diadematus Miller along with $T$. lanosus, thereby making $S$. intortus synonymous with $T$. lanosus (James, 1891). Cyathophycus siluriana, a new species of sponge discussed in the same paper, was later seen as synonymous with $T$. venosus by Osgood (1970).

The nature of the organism that produced trichophyciform burrows was addressed by Bergström (1976). He suggested that the characteristic striae were produced by an organism with long legs whose bases were close together, such as a decapod crustacean, and that the tracemaker was possibly an annelid. A trilobite origin was deemed unlikely by Osgood (1970) because there was no bilobation.

\section{Trichophycus lanosus Miller and Dyer, 1878a}

Pl. 13, fig. 4

\section{MATERIAL}

Two specimens: ROM 50089 and ROM 50090, plus additional field occurrences.

\section{DIAGNOSIS}

Usually sinuous Trichophycus with profusely striated ventral surface radiating from a button-like depression (after Osgood, 1970).

\section{DESCRIPTION}

These traces are preserved as convex hyporeliefs, the convex surface being completely covered by striae, $0.1-0.3 \mathrm{~mm}$ in diameter, giving the trace a shaggy appearance. Length is variable, the three examples collected having lengths between $1 \mathrm{~cm}$ and $3 \mathrm{~cm}$. Striae commence abruptly at a featureless breakage surface roughly circular in outline, the diameter of which is equal to that of the body of the trace. When seen in the vertical plane, this structure takes the form of tubes that follow a sinuous course towards what would presumably have been the sediment-water interface at the time of burrow formation. The walls of these tubes are featureless. Terminations of the traces are arcuate, no evidence of a reduction in the density of striae in these areas being seen.

\section{REMARKS}

The conditions that lead to the formation of Trichophycus lanosus are not wholly understood, though it has been suggested that the striae are produced by "a circlet of appendages or extensions surrounding [a] mouth," the sinuosity of the trace suggesting that the organism possessed a flexible vermiform body (Osgood, 1970:350). The presence of a sinuous vertical burrow at one end of each of the examples herein is believed to represent either a pre-existing vertical burrow (Skolithos) or a vertical burrow produced by the tracemaker while descending in search of nutrient-rich layers of sediment. When such a layer was encountered, the organism burrowed horizontally, thercby producing $T$. lanosus.
Trichophycus venosus Miller, 1879

Pl. 13, fig. 3

Trichophycus venosum Fritz, 1925:30-31, pl. 3, fig. 4. Teichichnus Kerr and Eyles, 1991, fig. 10c.

\section{MATERIAL}

Two suites in ROM collections: ROM 17492 [1253HR] consisting of three specimens, and ROM 17494 [1255HR] (partim), plus numerous field specimens.

\section{DIAGNOSIS}

Straight to gently curved, sometimes vertically branched Trichophycus displaying ventral striae that radiate posterolaterally from the midline (after Osgood, 1970).

\section{DESCRIPTION}

Specimens are preserved as concavo-convex full reliefs, convex hyporeliefs, or concave epireliefs, 9-27 $\mathrm{mm}$ in width by $28-110 \mathrm{~mm}$ in length. Convex surfaces display a characteristic pattern of striae, $0.3-1.0 \mathrm{~mm}$ in diameter, preserved in positive relief, of which three sets are distinguishable. One set comprises parallel striae running along burrow length, a second consists of striae radiating posteriorly $180^{\circ}$ from a point along the midline, and a third consists of striae radiating posterolaterally from the central axis at an angle of $5^{\circ}-10^{\circ}$. When specimens are viewed laterally, the third set of striae form an angle of approximately $40^{\circ}$ with the horizontal. All three sets of striae are not always present on the material, some displaying only the posterolaterally radiating variety. In some specimens, overprinting of several successive burrowing events due to vertical branching can be seen, retrusive spreite being seen in association with each. $T$. venosus is also preserved as concave epireliefs, though these forms are generally poorly preserved, displaying few or no striae. One specimen (ROM 50086) contains a specimen of Rusophycus pudicus on its bottom surface.

\section{REMARKS}

The presence of posterolaterally radiating striae on a convex ventral surface together with the presence of vertical branching distinguish these traces from the similar ichnogenera Teichichnus Seilacher and Pennatulites de Stefani (Osgood, 1970). We concur with Fritz's (1925) assignment of the ROM specimens to Trichophycus venosus. Several modes of formation have been suggested by various authors, including impression by plant material (Miller. 1879) and casting of small streams and rills (Fritz, 1925), though the most likely origin seems to be the production of fceding or dwelling burrows by small crustacean-like animals or setate annelids. The specimen of Rusophycus pudicus found in association with a specimen of Trichophycus venosus was possibly produced by a Rusophycus animal taking refuge in an abandoncd Trichophycus burrow. 


\section{Concluding Remarks}

The comparison of infaunal and epifaunal ichnotaxa can be useful when considering the relationships of tracemaking organisms to depositional events. In the Georgian Bay Formation, ichnotaxa are preserved essentially in four styles, namely, 1) full reliefs or endoreliefs in shale deposits (these include Diplocraterion, Palaeophycus, Planolites, and Trichophycus); 2) as convex epireliefs, hyporeliefs, full reliefs, or endoreliefs in calcareous sandstone deposits (these include Arenituba, Aulichnites, Cochlichnus, Diplocraterion, Gyrochorte, Palaeophycus, Phycodes, Planolites, Protovirgularia, Skolithos, and Trichophycus; 3 ) as convex or concave hyporeliefs on the soles of calcareous sandstone beds, the result of traces originally produced in underlying mudstone deposits being cast by overlying sandstone (these include Cruziana, Curvolithus, Didymaulichnus, Diplocraterion, Fustiglyphus, Gordia, Lingulichnus, Lockeia, Monomorphichnus, Rusophycus, and Trichophycus); and finally 4) as sandstone concave epireliefs produced by infaunal organisms originally living within overlying mud, gathering food along the mud-sand interface, Chondrites falling into this group.

Collectively, ichnotaxa in the Georgian Bay Formation are indicative of the Cruziana ichnofacies of Seilacher (1964, 1967). However, given the variable preservation of traces, it is tempting to equate certain ichnotaxa (e.g., Arenituba, Diplocraterion, Monocraterion, Skolithos) as reflecting opportunistic colonization of storm-deposited sand layers, producing trace fossils more typically associated with the Skolithos ichnofacies (cf. Vossler and Pemberton, 1989). Subsequently, calm or "fair-weather" periods following storm events would witness the deposition of muds, upon or within which deposit-feeding organisms produced traces such as Cruziana, Gordia, Lockeia, and Rusophycus, to name but several. Each series of storm events followed by periods of calm would witness a repetition of this situation.

Identity of the organism(s) that produced any given ichnotaxon is rarely known. Exceptions include Rusophuycus pudicus, several examples of which are believed to have been produced by the trilobite Flexicalymene meeki (Osgood, 1970), and Rusophycus cryptolithi, belicved to have been produced by the trilobite Cryptolithus, based on the nature of genal spine impressions as well as the overall geometry, both the trace and body fossils being buttonshaped (D. Rudkin, pers. comm.). Rusophycus polonicus is believed to have been produced by the trilobite Isotelus (Osgood, 1970; Seilacher, 1970), Lingulichnus verticalis by linguloid brachiopods (Hakes, 1976), and Lockeia and Protovirgularia by pelecypods (Osgood, 1970; Seilacher and Seilacher, 1994). The progenitors of most other ichnotaxa are unknown, and in many cases any given ichnotaxon may be produced by many different organisms, each displaying common behaviourial practices as illustrated, for example, by the compound examples of Planolites and Gyrochorte. Undoubtedly, however, many of the additional ichnotaxa described herein were produced by arthropods or worm-like organisms, most likely annelids.

Finally, we feel it useful to compare the ichnofaunal assemblage documented herein with that of the Cincinnatian of Ohio as monographed by Osgood (1970). Both sequences are of the same age, depositional environment, and biogeographic province, but the Georgian Bay Formation is dominated by siliciclastics and the Cincinnatian Series by carbonates. Comparison of these ichnofaunal suites is made in Appendix 3 which, incidentally, excludes Osgood's (1970) incertae sedis or invalid ichnospecies (see Häntzschel, 1975). Given the fact that several of Osgood's (1970) ichnotaxa have subsequently been re-assessed taxonomically (e.g., his Corophioides would now be regarded as Diplocraterion (Fürsich, 1974), his Walcottia as Protovirgularia (Seilacher and Seilacher, 1994), and his Fucusopsis as Palaeophycus (Pemberton and Frey, 1982)), the two suites compare favourably in terms of overall taxonomic content, suggesting that substrate composition (siliciclastic versus carbonate) was unimportant in their primary production. 


\section{Acknowledgements}

Dave Rudkin and Janet Waddington of the Royal Ontario Museum, Toronto, are thanked for providing access to material in the ROM collections, for the use of ROM facilities, and for providing repository numbers for new material. Nick Eyles is thanked for donating trace-fossil material collected by himself and Michael Kerr as part of their sedimentological analysis of the formation. Dave Keighley, Rob MacNaughton, and Yolande Norman are thanked for useful discussions and critiques of various aspects of this contribution. Bob McCulloch, Angel Gómez, and Diane Campbell are thanked for technical assistance. Translation of papers written in Czechoslovakian, German, Spanish, and Russian were provided by, respectively, Nina Chrzanowski and Yana Vanicek, Jürgen Kraus, Waldo
Perez, and Alan Reid. The Sobinovich family is thanked for granting access to their property to allow study of the type locality of the Georgian Bay Formation on the banks of Workman's Creek. Thanks are also due to Mike Arndt, Denise Cormier, Rowenna Gilbertson, and Graeme Weir for their support and interest throughout this project.

Financial support was provided by a Natural Sciences and Engineering Research Council of Canada operating grant to R. K. P. which is gratefully acknowledged. Last, but certainly not least, we are grateful to Peter Crimes and Guy Narbonne for their constructive reviews of an initial version of this manuscript and for providing many thought-provoking suggestions. 


\section{Literature Cited}

ACEÑOLAZA, F. G

1978 El Paleozoico inferior de Argentina según sus trazas fósiles. Ameghiniana 15:15-64.

ACENOLAZA, F. G., and F. DURAND

1973 Trazas fosiles del basamento cristalino del noreste Argentino. Boletin de la Asociation geologica de Cordoba 2:45-55.

ALPERT, S. P.

1974 Systematic review of the genus Skolithos. Journal of Paleontology 48:661-669.

1975 Planolites and Skolithos from the Upper Precambrian-Lower Cambrian, White-Inyo Mountains, Califomia. Journal of Paleontology 49:508-521.

ARCHER, A. W., and C. G. MAPLES

1984 Trace-fossil distribution across a marine-to-nonmarine gradient in the Pennsylvanian of southwestem Indiana. Journal of Paleontology 58:448-466.

ARCHER, A. W., J. H CALDER, M. R. GIBLING, R. D. NAYLOR, D. R. REID, and W. D. WIGHTMAN

1995 Invertebrate trace fossils and agglutinated foraminifera as indicators of marine influence within the classic Carboniferous section at Joggins, Nova Scotia, Canada. Canadian Journal of Earth Sciences 32:2027-2039.

BADVE, R. M.

1987 A reassessment of stratigraphy of Bagh Beds, Barwah area, Madhya Pradesh, with description of trace fossils. Journal of the Geological Society of India 30:106-120.

BADVE, R. M., and M. A. GHARE

1978 Jurassic ichnofauna of Kutch-I. Biovigyanam 4:125-140.

1980 Ichnofauna of the Bagh Beds from Deva River Valley south of Narmada. Biovigyanam 6:121-130.

BASSLER, R. S.

1915 Bibliographic Index of American Ordovician and Silurian Fossils. United States National Museum Bulletin 92, vol. 1. 718 pp.

BEARDS, R. J.

1967 Guide to the Subsurface Palaeozoic Stratigraphy of Southern Ontario. Ontario Department of Energy and Resources Management Paper 67-2. 19 pp.

BERGSTRÖM, J.

1976 Lower Palaeozoic trace fossils from eastem Newfoundland. Canadian Journal of Earth Sciences 13:1613-1633.

BILLINGS, E.

1862 Palaeozoic Fossils, vol. 1: Containing Descriptions and Figures of New or Little Known Species of Organic Remains from the Silurian Rocks. Geological Survey of Canada. 426 pp.

1872 On some fossils from the Primordial rocks of Newfoundland. Canadian Naturalist and Quarterly Journal of Science with the Proceedings of the
Natural History Society of Montreal, n.s. $6: 465-479$.

BJERSTEDT, T. W.

1987 Latest Devonian-Earliest Mississippian nearshore trace-fossil assemblages from West Virginia, Pennsylvania, and Maryland. Journal of Paleontology 61:865-889.

1988 Multivariate analyses of trace fossil distribution from an early Mississippian oxygen-deficient basin, central Appalachians. Palaios 3:53-68.

BRADSHAW, M. A.

1981 Paleoenvironmental interpretations and systematics of Devonian trace fossils from the Taylor Group (lower Beacon Supergroup), Antarctica. New Zealand Journal of Geology and Geophysics 24:615-652.

BROMLEY, R. G.

1990 Trace Fossils-Biology and Taphonomy. Unwin Hyman, London. 280 pp.

BROMLEY, R. G., and U. ASGAARD

1979 Triassic freshwater ichnocoenoses from Carlsberg fjord, east Greenland. Palaeogeography, Palaeoclimatology, Palaeoecology 28:39-80.

BROMLEY, R. G., and A. A. EKDALE

1984 Chondrites: A trace fossil indicator of Anoxia in sediments. Science 224:872-874.

BRONGNIART, A. T.

1828 Histoire des végétaux fossiles ou recherches botaniques et géologiques sur les végétaux renfermés dans les diverses couches du globe. Vol. 1. G. Dufour and E. d'Ocagne, Paris. 136 pp.

BUATOIS, L. A., and M. G. MÁNGANO

1990 Una asociacion de trazas fosiles del Carbonico lacustre del area de Los Jumes, Catamarca, Argentina; su comparacion con la ichnofacies de Scoyenia. V Congreso Argentino de Paleontologia y Biostratigrafia 1:77-81.

1993 Trace fossils from a Carboniferous turbiditic lake: implications for the recognition of additional nonmarine ichnofacies. Ichnos 2:237-258.

BUATOIS, L. A., M. G. MÁNGANO, X. WU, and G. ZHANG

1996 Trace fossils from Jurassic lacustrine turbidites of the Anyao Formation (central China) and their environmental and evolutionary significance. Ichnos 4:287-303.

BUCKMAN, J. O.

1995 A comment on annulate forms of Palaeophycus Hall 1847: with particular reference to $P$. 'annula. tus' sensu Pemberton and Frey 1982, and the erection of $P$. crenulatus ichnosp. nov. Ichnos 4:131-140.

BURKE, K., W. S. F. KIDD, and J. WALKER

1973 Palaeoenvironmental Studies of the Georgian Bay Formation at Erindalc, Ontario: Equatorial Shallow Marine Sedimentation on the Cratonic Margin of the Taconian Exogeosyncline. Unpublished manu- 
script. State University of New York, Albany. 29 pp. BYERLEY, M., and M. CONIGLIO

1989a Stratigraphy and sedimentology of the Upper Ordovician Georgian Bay Formation, Manitoulin Island and Bruce Peninsula. Geoscience Research Grant Program Summary of Research 1988-1989, Grant 351, Ontario Geological Survey Miscellaneous Paper 143:227-237.

1989 b Sedimentology of a carbonate-siliciclastic, stormdominated shelf; Georgian Bay Formation, NE Michigan Basin, Ontario. Geological Association of Canada, Mineralogical Association of Canada, Annual Meeting, Program with Abstracts 14:76.

1991 Stratigraphy and sedimentology of the Upper Ordovician Georgian Bay Formation, Manitoulin Island and Bruce Peninsula-evaluation of hardgrounds, biostromes and storm beds for regional correlation. Geoscience Research Grant Program Summary of Research 1990-1991, Grant 351, Ontario Geological Survey Miscellaneous Paper 156:3-15.

CALEY, J. F.

1936 The Ordovician of Manitoulin Island. Geological Survey of Canada Memoir 202:21-92.

1940 Palaeozoic Geology of the Toronto-Hamilton Area, Ontario. Geological Survey of Canada Memoir 224. $284 \mathrm{pp}$.

CHAMBERLAIN, C. $\mathrm{K}$.

1971 a Bathymetry and paleoecology of Ouachita geosyncline of southeastem Oklahoma as determined from trace fossils. Bulletin of the American Association of Petroleum Geologists 55:34-50.

1971b Morphology and ethology of trace fossils from Ouachita Mountains, southeast Oklahoma. Journal of Paleontology 45:212-246.

CLARKE, R. B.

1964 Dynamics in Metazoan Evolution. The Origin of the Coelom and Segments. Clarendon, Oxford. 313 pp.

COUREL, L., G. DEMATHIEU, and J.-C. GALL

1979 Figures sédimentaires et traces d'origine biologique du Trias Moyen de la bordure Orientale du Massif Central-signification sédimentologique et paléoécologique. Géobios 12:379-397.

CRIMES, T. P.

1970 Trilobite tracks and other trace fossils from the Upper Cambrian of North Wales. Geological Joumal 7:47-68.

1987 Trace fossils and correlation of Late Precambrian and Early Cambrian strata. Geological Magazine 124:97-119.

CRIMES, T. P., and M. M. ANDERSON

1985 Trace fossils from Late Precambrian-Early Cambrian strata of southeastern Newfoundland (Canada): temporal and environmental implications. Journal of Paleontology 59:310-343.

CRIMES, T. P., and J. D. CROSSLEY

1991 A diverse ichnofauna from Silurian flysch of the Abcrystwyth Grits Formation, Wales. Geological Joumal 26:27-64.
CRIMES, T. P., and J. C. HARPER, eds.

1970 Trace Fossils. Geological Journal, Special Issue 3. Seel House Press, Liverpool. 547 pp.

CRIMES, T. P., and G. J. H. McCALL

1995 A diverse ichnofauna from Eocene-Miocene rocks of the Makran Range (S.E. Iran). Ichnos 3:231-258.

CRIMES, T. P., I. LEGG, A. MARCOS, and M. ARBOLEYA

1977 ?Late Precambrian-low Lower Cambrian trace fossils from Spain. In T. P. Crimes and J. C. Harper, eds., Trace Fossils 2. Geological Journal, Special Issue 9, pp. 91-138.

DAM, G.

1990 Taxonomy of trace fossils from the shallow marine Lower Jurassic Neill Klinter Formation, East Greenland. Bulletin of the Geological Society of Denmark 38:119-144.

DAWSON, J. W.

1864 On the fossils of the genus Rusophycus. The Canadian Naturalist and Geologist 1:363-367.

DEKAY, J. E.

1824 Note on the organic remains, termed Bilobites, from the Catskill Mountains. Lyceum of Natural History of New York, Annals 1:45-49.

DEMATHIEU, G. R.

1985 Trace fossil assemblages in Middle Triassic marginal marine deposits, eastem border of the Massif Central, France. In H. A. Curran, ed., Biogenic Structures: Their Use in Interpreting Depositional Environments. Society of Economic Paleontologists and Mineralogists, Special Publication 35, pp. 53-66.

EAGAR, R. M. C., S. A. OKOLO, and G. F. WALTERS

1983 Trace fossils as evidence in the evolution of Carbonicola. Proceedings of the Yorkshire Geological Society 44:283-303.

EAGAR, R. M. C., J. G. BAINES, J. D. COLLINSON, P. G. HARDY, S. A. OKOLO, and J. E. POLLARD

1985 Trace fossil assemblages and their occurrence in Silesian (Mid-Carboniferous) deltaic sediments of the Central Pennine Basin, England. In H. A. Curran ed., Biogenic Structures: Their Use in Interepreting Depositional Envrionments. Society of Economic Paleontologists and Mineralogists Special Publication 35, pp. 99-149.

ECKERT, J. D.

1987 Pycnocrinus altilis, a new Late Ordovician channcldwelling crinoid from southem Ontario. Canadian Joumal of Earth Sciences 24:851-859.

EKDALE, A. A., R. G. BROMLEY, and S. G. PEMBERTON

1984 Ichnology, Trace Fossils in Sedimentology and Stratigraphy. Society of Economic Paleontologists and Mineralogists Short Coursc No. 15. 317 pp.

ELLIOTT, R. E.

1985 An interpretation of the trace fossil Cochlichnus kochi (Ludvig) from the East Pennine coal ficld of Britain. Procecdings of the Yorkshire Geological Society 45: 183-187. 
EMMONS, E.

1844 The Taconic System; Based on Observations in New York, Massachusetts, Maine, Vermont and Rhode Island. Caroll and Cook, Albany. 68 pp.

FENTON, C. L., and M. A. FENTON

1937 Burrows and trails from Pennsylvanian rocks of Texas. American Midland Naturalist 18:1079-1084.

FILLION, D., and R. K. PICKERILL

1984a On Arthraria antiquata Billings, 1872 and its relationship to Diplocraterion Torell, 1870 and Bifungites Desio, 1940. Joumal of Paleontology 58:683-696.

1984b Systematic ichnology of the Middle Ordovician Trenton Group, St. Lawrence Lowland, eastem Canada. Maritime Sediments and Atlantic Geology 20:1-41.

1990a lchnology of the Upper Cambrian? to Lower Ordovician Bell lsland and Wabana Groups of Eastem Newfoundland. Palaeontographica Canadiana 7. 119 pp.

1990b Comments on "Substrate control of Lower Cambrian trace fossils from Bornholm, Denmark." Palaeogeography, Palaeoclimatology, Palaeoecology $80: 345-350$.

FOERSTE, A. F.

1912 The Ordovician section in the Manitoulin Island area of Lake Huron. Ohio Naturalist 13:37-48.

1916 Upper Ordovician Formations in Ontario and Quebec. Geological Survey of Canada Memoir 83. 279 pp.

1924 Upper Ordovician Faunas of Ontario and Quebec. Geological Survey of Canada Memoir 138. 255 pp.

FREY, R. W., and J. D. HOWARD

1985 Trace fossils from the Panther Member, Star Point Formation (Upper Cretaceous), Coal Creek Canyon, Utah. Journal of Paleontology 59:370-404.

1990 Trace fossils and depositional sequences in a clastic shelf setting, Upper Cretaceous of Utah. Journal of Paleontology 64:803-820.

FREY, R. W., and S. G. PEMBERTON

1984 Trace fossil facies models. In R. G. Walker, ed., Facies Models (2nd ed.). Geoscience Canada, Reprint Series 1, pp. 189-208.

FREY, R. W., S. G. PEMBERTON, and T. D. A. SAUNDERS

1990 Ichnofacies and bathymetry: a passive relationship. Journal of Paleontology 64:155-158.

FRITSCH, A. (= FRIC, A. J.)

1908 Problematica Silurica. In J. Barrande, Système Silurien du Centre de la Bohême. Published from Barrande Fund by author and editor, Prague. 28 pp.

FRITZ, M. A

1925 Hydrozoa, Echinodermata, Trilobita, and markings. In The stratigraphy and paleontology of Toronto and vicinity. In Thirty-Second Annual Report of the Ontario Department of Mines, pp. 1-47.

1926 The stratigraphy and palaeontology of the Workman's Creek section of the Cincinnatian series of Ontario. Royal Society of Canada Transactions 20:77-108.
1946 A Rhopalonaria in the Dundas Formation at Toronto (Ontario). Joumal of Paleontology 20:87.

1951 The pelecypod genus Vlasta in the Ordovician of North America. Journal of Palcontology 25:696-698.

1970 Redescription of type specimens of the bryozoan Hallopora from the upper Ordovician of Toronto region, Ontario. Geological Association of Canada Proceedings 21:15-24.

1971 The Trepostomatous Bryozoan Stigmatella carenu. lata diversa Parks and Dyer (1922), a Synonym for Mesotrypa diversa (Parks and Dyer). Royal Ontario Museum Life Sciences Occasional Paper 18. 6 pp.

FÜRSICH, F. T.

1974 On Diplocraterion Torell 1870 and the significance of morphological features in vertical spreiten-bearing, U-shaped trace fossils. Joumal of Paleontology 48:952-962.

GLAESSNER, M. F.

1969 Trace fossils from the Precambrian and basal Cambrian. Lethaia 2:369-393.

GLUSZEK, A.

1995 Invertebrate trace fossils in the continental deposits of an Upper Carboniferous coal-bearing succession, Upper Silesia, Poland. Studia Geologia Polonica 108:171-202.

GOLDRING, R.

1962 The trace fossils of the Baggy Beds (Upper Devonian) of North Devon, England. Paläontologische Zeitschrift 36:232-251.

GORRELL, H. A.

1952 The Dundas Formation as exposed in the excavations for the Toronto Transportation Commission subway (Ontario). Geological Association of Canada Proceedings 5:83-93.

HAKES, W. G.

1976 Trace fossils and depositional environment of four clastic units, Upper Pennsylvanian megacyclothems, northeast Kansas. The University of Kansas Paleontological Contributions, Article 63:1-46.

1977 Trace fossils in Late Pennsylvanian cyclothems, Kansas. In T. P. Crimes and J. C. Harper, eds., Trace Fossils 2. Geological Joumal, Special Issue 9, pp. 209-226.

1985 Trace fossils from brackish-marine shales, Upper Pennsylvanian of Kansas, U.S.A. In H. A. Curran ed., Biogenic Structures: Their Use in Interpreting Depositional Environments. Society of Economic Paleontologists and Mineralogists, Special Publication 35, pp. 21-35.

HALDEMAN, S. S.

1840 Supplement to Number One of "A monograph of the Limniades, or fresh-water univalve shells of North America", Containing Descriptions of Apparently New Animals in Different Classes, and the Names and Characters of the Subgenera in Paludina and Anculosa. J. Dobson, Philadelphia. 3 pp. 
HALL, J.

1843 Geology of New York. Part IV. Survey of the Fourth Geological District. Carroll and Cook, Albany. 683 pp.

1847 Palaeontology of New York, Volume 1. Containing Descriptions of the Organic Remains of the Lower Division of the New York System (Equivalent to the Lower Silurian Rocks of Europe). C. van Benthuysen, Albany. 338 pp.

1852 Palaeontology of New York, Volume 2. Containing Descriptions of the Organic Remains of the Lower Middle Division of the New York System (Equivalent in Part to the Middle Silurian Rocks of Europe). C. van Benthuysen, Albany. 368 pp.

HALLAM, A.

1970 Gyrochorte and other trace fossils in the Forest Marble (Bathonian) of Dorset, England. In T. P. Crimes and J. C. Harper, eds., Trace Fossils. Geological Journal, Special Issue 3, pp. 189-200.

HAN, Y., and R. K. PICKERILL

1994a Phycodes templus isp. nov. from the Lower Devonian of northwestern New Brunswick, eastern Canada. Atlantic Geology 30:37-46.

1994b Palichnology of the Lower Devonian Wapske Formation, Perth-Andover-Mount Carleton region, northwestern New Brunswick, eastern Canada. Atlantic Geology 30:217-245.

1994c Taxonomic reassessment of Protovirgularia M'Coy 1850 with new examples from the Paleozoic of New Brunswick, eastern Canada. Ichnos 3:203-212.

1995 Taxonomic review of the ichnogenus Helminthopsis Heer 1877 with a statistical analysis of selected ichnospecies. Ichnos 4:83-118.

HÄNTZSCHEL, W.

1962 Trace Fossils and Problematica. In R. G. Moore, ed., Treatise on Invertebrate Paleontology, Part W, Miscellanea. Geological Society of America and University of Kansas Press, New York and Lawrence, Kansas, pp. W177-W245.

1975 Trace Fossils and Problematica. In C. Teichert, ed., Treatise on Invertebrate Paleontology, Part W, Miscellanea, Supplement 1 (2nd ed.). Geological Society of America and University of Kansas Press, Boulder, Colorado and Lawrence, Kansas, pp. W1-W269.

HAUGH, B. N.

1979 Late Ordovician Channel-Dwelling Crinoids from Southern Ontario, Canada. American Museum Novitates 2665. 24 pp.

HEER, O.

1864-1865 Die Urwelt der Schweiz. Mit sieben landschaftlichten Bildern, elf Taflen, einer geologischen Uebersichtskarte der Schweitz und zahlreichen in den Text eingedruckten Abbildungen. Friedrich Schulthess, Zürich. 622 pp.

1877 Flora Fossilis Helvetiae. Dic vorweltliche Flora der Schweiz. J. Würster \& Company, Zürich. 182 pp.
HEINBERG, C.

1970 Some Jurassic trace fossils from Jameson Land (East Greenland). In T. P. Crimes and J. C. Harper, eds., Trace Fossils. Geological Joumal, Special Issue 3, pp. 227-234.

1973 The internal structure of the trace fossils Gyrochorte and Curvolithus. Lethaia 6:227-238.

HITCHCOCK, E.

1858 Ichnology of New England. A Report on the Sandstone of the Connecticut Valley, Especially Its Footprints. W. White, Boston. 220 pp.

HOFMANN, H. J.

1991 Computer simulation of trace fossils with random patterns, and the use of goniograms. Ichnos $1: 15-22$.

HOFMANN, H. J., and I. M. PATEL

1989 Trace fossils from the type "Etcheminian Series" (Lower Cambrian Ratcliffe Brook Formation), Saint John area, New Brunswick, Canada. Geological Magazine 126:139-157.

HOFMANN, H. J., M. P. CECILE, and L. S. LANE

1994 New occurrence of Oldhamia and other trace fossils in the Cambrian of the Yukon and Ellesmere Island, arctic Canada. Canadian Joumal of Earth Sciences 31:767-782.

HOWARD, J. D., and R. W. FREY

1984 Characteristic trace fossils in nearshore to offshore sequences, Upper Cretaceous of east-central Utah. Canadian Journal of Earth Sciences 21:200-219.

HOWELL, B. F.

1944 A new Skolithos from the Cambrian Hardyston Formation of Pennsylvania. Wagner Free Institute of Science Bulletin 19:41-44.

1946 Silurian Monocraterion clintonense burrows showing the aperture. Wagner Free Institute of Science Bulletin 21:29-40.

ICZN (INTERNATIONAL COMMISSION ON ZOOLOGICAL NOMENCLATURE)

1985 International Code of Zoological Nomenclature. Third edition adopted by the Twentieth General Assembly of the International Union of Biological Sciences, February, 1985. W. D. L. Ride, C. W. Sabrosky, G. Bernardi, and R. V. Melville, eds., International Trust for Zoological Nomenclature in association with British Museum (Natural History), London and University of California Press, Berkeley and Los Angeles. 338 pp.

JAMES, J. F.

1884 The fucoids of the Cincinnati Group. Journal of the Cincinnati Society of Natural History 7:124-132.

1885 The fucoids of the Cincinnati Group. Journal of the Cincinnati Socicty of Natural History 8:151-166.

1891 Manual of the Palcontology of the Cincinnati Group. Journal of the Cincinnati Society of Natural History 14:45-72. 
JA.MES. U.P.

1879 Description of new specics of fossils and remarks on some others, from the Lower and Upper Silurian rocks of Ohio. The Palcontologist 3:17-24.

KEIGHLEY, D., and R. K. PICKERILL

1995 The ichnotaxa Palaeophycus and Planolites: historical perspectives and recommendations. Ichnos 3:301-309.

1996 Small Cruziana, Rusophycus, and related ichnotaxa from eastern Canada: the nomenclatural debate and systematic ichnology. Ichnos 4: 261-285.

KEMPER, E.

1968 Einige Bemerkungen über die Sedimentationsverhältnisse und die fossilen Lebensspuren des Bentheimer Sandsteins (Valanginium). Geologisches Jahrbuch 86:49-106.

KERR. M. and N. EYLES

1991 Storm-deposited sandstones (tempestites) and related ichnofossils of the Late Ordovician Georgian Bay Formation, southem Ontario, Canada. Canadian Journal of Earth Sciences 28:266-282.

KNOX, R. W. O'B.

1973 Ichnogenus Corophioides. Lethaia 6:133-146. KOBLUK, D. R.

1980 Upper Ordovician (Richmondian) cavity-dwelling (coelobiontic) organisms from southem Ontario. Canadian Journal of Earth Sciences 17:1616-1627.

KOTAKE, $\mathrm{N}$

1991 Packing process for the filling material in Chondrites. Ichnos 1:277-285.

KSIĄZZKIEWICZ, M.

1970 Observations on the ichnofauna of the Polish Carpathians. In T. P. Crimes and J. C. Harper, eds., Trace Fossils. Geological Journal, Special Issue 3, pp. 283-322.

1977 Trace fossils in the flysch of the Polish Carpathians. Palaeontologia Polonica 36:1-208.

LAJTAI, E. Z.

1969 Stratigraphy of the University Subway, Toronto, Canada. Geological Association of Canada Proceedings 20:17-23.

LESCZYŃSKI, S., and A. SEILACHER

1991 Ichnocoenoses of a turbidite sole. Ichnos 1:293-303.

LIBERTY, B. A.

1953 Stratigraphy and Palaeontology of the Lake Simcoe District, Ontario. Unpublished Ph.D. thesis, University of Toronto. 209 pp.

1954 Ordovician of Manitoulin Island. In The Stratigraphy of Manitoulin Island, Ontario, Canada. Michigan Geological Society Annual Field Trip, June 19-20, 1954, pp. 7-22.

1964 Upper Ordovician stratigraphy of the Toronto area. In Geology of Southern Ontario. American Association of Petroleum Geologists/Socicty of Economic Paleontologists and Mineralogists Guidebook, pp. 43-54.
1968 Ordovician and Silurian Stratigraphy of Manitoulin Island, Ontario. Michigan Basin Geological Society Field Trip, 1968, pp. 25-37.

1969 Palacozoic Geology of the Lake Simcoc Area, Ontario. Geological Survey of Canada Memoir 355. $201 \mathrm{pp}$.

1978 Ordovician nomenclature of Manitoulin 1sland. In J. T. Sanford and R. E. Mosher, eds., Geology of the Manitoulin Area. Michigan Basin Geological Society Field Trip, 1978, pp. 43-45.

LIBERTY, B. A., and T. E. BOLTON

1971 Paleozoic Geology of the Bruce Peninsula Area, Ontario. Geological Survey of Canada Memoir 360. $163 \mathrm{pp}$.

LIÑáN, E.

1984 Los icnofósiles de la Formación Torreárboles (Precámbrico?-Cámbrico Inferior) en los alrededores de Fuente de Cantos, Badajoz. Cuademos do Laboratorio Xeologico de Laxe 8:47-74.

MAILLARD, G.

1887 Considérations sur les fossiles décrits comme algues. Société Paléontolgique de la Suisse, Mémoire 14:1-40.

MATTHEW, G. F.

1891 Illustrations of the fauna of the St. John Group, No. 5. Transactions of The Royal Society of Canada 8:123-166.

MAPLES, C. G., and L. J. SUTTNER

1990 Trace fossils and marine-nonmarine cyclicity in the Fountain Formation (Pennsylvanian: Morrowan/ Atokan) near Manitou Springs, Colorado. Journal of Paleontology 64:859-880.

McCANN, T.

1990 Distribution of Ordovician-Silurian ichnofossil assemblages in Wales-implications for Phanerozoic ichnofaunas. Lethaia 23:243-255.

1993 A Nereites ichnofacies from the OrdovicianSilurian Welsh Basin. Ichnos 3:39-56.

McCANN, T., and R. K. PICKERILL

1988 Flysch trace fossils from the Cretaceous Kodiak Formation of Alaska. Joumal of Paleontology $62: 330-348$.

McCOY, F.

1850 On some genera and species of Silurian Radiata in the collection of the University of Cambridge. Annals and Magazine of Natural History, Series 2, 6:270-290.

METZ, R.

1987 Sinusoidal trail formed by a Recent biting midge (Family Ceratopogonidae): trace fossil implications. Journal of Paleontology 61:312-314.

1989 Scoyenia ichnofacies from the Passaic Formation (Upper Triassic) near Milford, New Jersey. Northeastern Geology 11:212-217.

1992 Trace fossils from the Lower Jurassic nonmarine Towaco Formation, New Jersey. Northeastern Geology 14:29-34.

1995 Ichnologic study of the Lockatong Formation (Late 
Triassic), Newark Basin, southeastem Pennsylvania. Ichnos 4:43-51.

1996 Newark Basin ichnology: the Late Triassic Perkasie Member of the Passaic Formation, Sanatoga, Pennsylvania. Northeastern Geology and Environmental Sciences 18:118-129.

MIKULÁŠ, R.

1991 Trace fossils from the Kosov Formation of the Bohemian Upper Ordovician. Sborniik Geologických Věd 32:9-54.

1992 Trace fossils from the Klabava Formation (Early Ordovician), Czechoslovakia. Acta Universitatis Carolinae-Geologica 3-4:385-419.

MILLER, G. D.

1986 The sediments and trace fossils of the Rough Rock Group on Cracken Edge, Derbyshire. Mercian Geologist 10:189-202.

MILLER, M. F.

1984 Distribution of biogenic structures in Paleozoic nonmarine and marine-margin sequences: an actualistic model. Journal of Paleontology 58:550-570.

MILLER, S. A.

1875 Some new species of fossils from the Cincinnati Group and remarks upon some described forms. Cincinnati Quarterly Journal of Science 2:349-355.

1879 Description of twelve new fossil species and remarks upon others. Journal of the Cincinnati Society of Natural History 2:104-118.

1889 North American Geology and Palaeontology for the use of Amateurs, Students, and Scientists. Western Methodist Book Concern, Cincinnati. 718 pp.

MILLER, S. A., and C. B. DYER

1878a Contributions to Palaeontology Number 1. Journal of the Cincinnati Society of Natural History 1:24-39.

1878b Contributions to Palaeontology Number 2. Privately published, Cinncinnati, Ohio. $11 \mathrm{pp}$.

MUNIZ, G. C. B.

1980 Cochlichnus lagartensis ichnosp. nov., ichnofóssil da Formaçâo Lagarto, Grupo Estância, no. Estado de Sergipe. Academia Brasileira de Ciencias, Anais, 5:3101-3103.

1985 Cochlichnus sousensis, icnospécie da formaçâo Sousa, Grupo Rio do Peixe, no. Estado da Paraíba. In Coletânea de trabalhos paleontológicas. Trabalhos apresentados VIII congresso Brasileiro de paleontologia, 1983. Ministério das minas e energia, departmento nacional da produção mineral, pp. 239-241.

MURCHISON, R. I.

1850 Memoria sulla struttura geologica delle Alpi, delle Apennini e dei Carpazi. Stamperia granucale, Firenze. $528 \mathrm{pp}$.

NARBONNE, G. M.

1984 Trace fossils in Upper Silurian tidal flat to basin slope carbonates of Arctic Canada. Journal of Paleontology 58:398-415.
NICHOLSON, H. A

1873 Contributions to the study of the errant annelides of the older Palaeozoic rocks. Royal Society of London Proceedings 21:288-290. [=Geological Magazine, 10:309-310.][abstract]

NICHOLSON, H. A., and G. J. HINDE

1874 Notes on the fossils of the Clinton, Niagara and Guelph formations of Ontario, with descriptions of new species. Canadian Journal of Earth Science, Literature and History 14:137-157, 137-144 (mistake in pagination: pp. $153-160$ misnumbered as pp. 137-144).

OKULITCH, V. J.

1939 A note on wave markings in the Dundas Formation at Toronto. Canadian Field-Naturalist 53:85-86.

ÖPIK, A. A.

1929 Studien über das estnische Unterkambrium (Estonium). I-IV. Universität Tartuensis, Acta Comment. A. 15.56 pp.

ORBIGNY, A. D'.

1842 Voyages dans l'Amerique meridional (le Brésil, la république Argentine, la Patagonie, la république du Chili, la république de Bolivia, la république du Pérou), executé pendent les anées 1826, 1827, 1828, $1829,1830,1831,1832$, et 1833, Paléontologie, Paris, Pitois-Leverault; Strasbourge, Ve. Leverault. Tome $3,4^{\mathrm{e}}$ partie, $188 \mathrm{pp} ., 22 \mathrm{pls}$.

ORŁOWSKI, S.

1992 Trilobite trace fossils and their stratigraphical significance in the Cambrian sequence of the Holy Cross Mountains, Poland. Geological Journal 27:15-34.

ORŁOWSKI, S., A. RADWAŃSKI, and P. RONIEWICZ

1970 The trilobite ichnocoenoses in the Cambrian sequence of the Holy Cross Mountains. In T. P. Crimes and J. C. Harper, eds., Trace Fossils. Geological Journal, Special Issue 3, pp. 345-360.

OSGOOD, R. G., Jr.

1970 Trace fossils of the Cincinnati Area. Palaeontographica Americana 6:281-444.

OSGOOD, R. G., Jr., and W. T. DRENNEN III

1975 Trilobite trace fossils from the Clinton Group (Silurian) of east-central New York State. Bulletins of American Paleontology 67:299-348.

PALIJ, V. M., E. POSTI, and M. A. FEDONKIN

1983 Soft-bodied Metazoa and animal trace fossils in the Vendian and early Cambrian. In A. Urbanck and A. Y. Rozanov, eds., Upper Prccambrian and Cambrian Palaeontology of the East-European Platform. Publishing House Wydawnictwa Gcologiczne, Warszawa, pp. 56-94.

PARKS, W. A.

1925 Stratigraphy and corrclation of the Dundas Formation. In The stratigraphy and palcontology of Toronto and vicinity. In Thirty-Second Annual Report of the Ontario Department of Mines, pp. 99-116. 
1928 Faunas and stratigraphy of the Ordovician black shales and related rocks in southern Ontario. Transactions of the Royal Society of Canada, 3rd series 22:39-90.

PEMBERTON, S. G., and R. W. FREY

1982 Trace fossil nomenclature and the PlanolitesPalaeophycus dilemma. Journal of Paleontology 56:843-881.

1984 Ichnology of storm-influenced shallow marine sequence: Cardium Formation (upper Cretaceous) at Seebe, Alberta. In D. F. Stott and D. J. Glass, eds., The Mesozoic of Middle North America. Canadian Socicty of Petroleum Geologists, Memoir 9, pp. 281-304.

PICKERILL, R. K.

1980 Phanerozoic flysch trace fossil diversity-observations based on an Ordovician flysch ichnofauna from the Aroostook-Matapedia Carbonate Belt of northern New Brunswick. Canadian Journal of Earth Sciences 17:1259-1270.

1981 Trace fossils in a Lower Palaeozoic submarine canyon sequence-the Siegas Formation of northwestern New Brunswick, Canada. Maritime Sediments and Atlantic Geology 17:36-58.

1990 Nonmarine Paleodictyon from the Carboniferous Albert Formation of southern New Brunswick. Atlantic Geology 26:157-163.

1992 Carboniferous nonmarine invertebrate ichnocoenoses from southern New Brunswick, eastern Canada. Ichnos 2:21-35.

1994 Nomenclature and taxonomy of invertebrate trace fossils. In S. K. Donovan, ed., The Palaeobiology of Trace Fossils. Belhaven Press, London, pp. 3-42.

PICKERILL, R. K., and G. M. NARBONNE

1995 Composite and compound ichnotaxa: a case example from the Ordovician of Québec, eastern Canada. Ichnos 4:53-69.

PICKERILL, R. K., and J. S. PEEL

1990 Trace fossils from the Lower Cambrian Bastion Formation of North-East Greenland. In J. S. Peel, ed., Lower Cambrian Trace Fossils from Greenland. Grønlands geologiske Undersøgelse, Rapport 147, pp. 5-43.

1991 Gordia nodosa isp. nov. and other trace fossils from the Cass Fjord Formation (Cambrian) of North Greenland. Grønlands geologiske Undersøgelse, Rapport 150:15-28.

PIEŃKOWSKI, G., and E. WESTWALEWICZ-MOGILSKA

1986 Trace fossils from the Podhale flysch basin, Poland-an example of ecologically based lithocorrelation. Lethaia 19:53-65.

RADWAŃSKI, A., and P. RONIEWICZ

1963 Upper Cambrian trilobite ichnocoenosis from Wielka Wisniowka (Holy Cross Mountains, Poland). Acta Palaeontologica Polonica 8:259-276.

\section{RICHTER, REINHARD}

1850 Aus der thüringischen Grauwacke. Deutsche Geologische Gesellschaft, Zeitschrift 2:198-206.
1853 Gaea von Salfeld, Programm der Realschule Saalfeld: $3-32$.

RICITER, RUDOLPH

1927 Die fossilen Fährten und Bauten der Würmer, ein Überblick über ihre biologischen Grundformen und deren geologische Bedeutung. Paläontologische Zeitschrift 9:193-240.

RINDSBERG, $A$.

1994 Ichnology of the Upper Mississippian Hartselle Sandstone of Alabama, with Notes on Other Carboniferous Formations. Geological Survey of Alabama, Bulletin 158. 107 pp.

ROMANO, M., and M. A. WHYTE

1987 A limulid trace fossil from the Scarborough Formation (Jurassic) of Yorkshire; its occurrence, taxonomy and interpretation. Proceedings of the Yorkshire Geological Society 46:85-95.

RONIEWICZ, P., and G. PIEŃKOWSKI

1977 Trace fossils of the Podhale Flysch basin. In T. P. Crimes and J. C. Harper, eds., Trace Fossils 2. Geological Journal, Special lssue 9, pp. 273-288.

ROUAULT, $\mathrm{M}$.

1850 Note préliminaire (1) sur une nouvelle formation découverte dans le terrain Silurien inférieur de la Bretagne. Société Géologique de France, Bulletin, série 2:724-744.

RUDKIN, D. M.

1981 Trilobites and associated trace fossils from the Georgian Bay Formation (Upper Ordovician), Toronto region. Maritime Sediments and Atlantic Geology 17:61.

RUSSELL, D. J., and P. G. TELFORD

1983 Revisions to the stratigraphy of the Upper Ordovician Collingwood beds of Ontario-a potential oil shale. Canadian Joumal of Earth Sciences 20:1780-1790.

SANFORD, B. V.

1961 Subsurface stratigraphy of Ordovician rocks in southwestern Ontario. Geological Survey of Canada Paper 60-26.

SANFORD, J. T., and R. E. MOSHER

1978 Road Log, 1978 field trip, Manitoulin Island. In J. T. Sanford and R. E. Mosher, eds., Geology of the Manitoulin Area. Michigan Basin Geological Society Field Trip, 1978, pp. 3-28.

SAPORTA, L. C. J. G. DE

1872-1873 Paléontologie française ou description des fossiles de la France (commencée par Alcide d'Orbigny et) continuée par une réunion de paléontologistes sous la direction d'un comité special. Séries 2. Végetaux. Plantes Jurassiques, 1-10. G. Masson, Paris, 506 pp.

SARJEANT, W. A. S.

1979 Code for Trace Fossil Nomenclature. Palaeogeography, Palaeoclimatology, Palaeoecology 28:147- 167. [Inadvertently attached to paper by P. B. Basan, 1979.] 
SARLE, C. J.

1906 Arthrophycus and Dadalus of burrow origin. Proceedings of the Rochester Academy of Science 4:203-210.

SCHINDEWOLF, O. H.

1921 Studien aus dem Marburger Buntsandstein. 1, 2. Senckenbergiana 3:33-49.

\section{SEILACHER, A.}

1953 Studien zur Palichnologie 2. Die fossilen Ruhespuren (Cubichnia). Neues Jahrbuch für Geologie und Paläontologie, Abhandlungen 98:87-124.

1955 Spuren und Fazies im Unterkambrium. In O. H. Schindewolf and A. Seilacher, Beiträge zur Kenntnis des Kambriums in der Salt Range (Pakistan). Akademie der Wissenschaften und der Literatur zu Mainz, mathematisch-naturwissenschaftliche Klasse, Abhandlungen 10, pp. 373-399.

1964 Biogenic sedimentary structures. In J. Imbrie and N. D. Newell, eds., Approaches to Paleoecology. Wiley, New York, pp. 296-316.

1967 Bathymetry of trace fossils. Marine Geology 5:189-200.

1970 Cruziana stratigraphy of non-fossiliferous Palaeozoic sandstones. In T. P. Crimes and J. C. Harper, eds., Trace Fossils. Geological Joumal, Special Issue 3, pp. 447-476.

1991 An updated Cruziana stratigraphy of Gondwanan Palaeozoic sandstones. In M. J. Salem, O. S. Hammuda, and B. A. Eligoubi, eds., Geology of Libya, vol. IV, Third Symposium on the Geology of Libya, Tripoli, pp. 1565-1581.

SEILACHER, A., and E. SEILACHER

1994 Bivalvian trace fossils: A lesson from actuopaleontology. CFS, Courier Forschungsinstitut Senckenberg 169:5-15.

SIMPSON, S.

1957 On the trace-fossil Chondrites. Quarterly Journal of the Geological Society of London 112:475-499.

STANLEY, D. C. A., and R. K. PICKERILL

1993a Fustiglyphus annulatus from the Ordovician of Ontario, Canada, with a systematic review of the ichnogenera Fustiglyphus Vyalov 1971 and Rhabdoglyphus Vassoievich 1951. Ichnos 3:57-67.

1993b Shallow marine Paleodictyon from the Upper Ordovician Georgian Bay Formation of southern Ontario. Atlantic Geology 29:115-119.

1994 Planolites constriannulatus isp. nov. from the Late Ordovician Georgian Bay Formation of southern Ontario. Ichnos 3:119-123.

1995 Arenituba, a new name for the trace fossil ichnogenus Micatuba Chamberlain, 1971. Journal of Paleontology 68:612-614.

STERNBERG, K. M. GRAF VON

1833 Versuch einer geognostisch-botanischen Darstellung der Flora der Vorwelt, 5, 6. Johann Spurny, Prague. 80 pp.
SZMUC, E. J., R. G. OSGOOD, Jr., and D. W. MEINKE

1976 Lingulichnites, a new trace fossil genus for lingulid brachiopod burrows. Lethaia 9:163-167.

1977 Synonymy of the ichnogenus Lingulichnites Szmuc, Osgood \& Meinke, 1976, with Lingulichnus Hakes, 1976. Lethaia 10:106.

TASCH, P.

1968a A Permian trace fossil from the Antarctic Ohio range. Transactions of the Kansas Academy of Science 71:33-37.

1968b Trace fossils trom the Permian Polarstar Formation Sentinel Mountains, Antarctica. Transactions of the Kansas Academy of Science 71:184-194.

TORELL, O. M.

1870 Petrificata Suecana Formationis Cambricae. Lunds Universitet, Årsskrift 6:1-14.

VIALOV, O. S.

1971 Rare Mesozoic problematica from the Pamir and Caucasus. Paleontologikheskiy Sbornik, 7:85-93. (In Russian)

VOSSLER, S. M., and S. G. PEMBERTON

1989 Superabundant Chondrites: a response to storm buried organic material? Lethaia 21:94.

WADDINGTON, J., P. H. VON BITTER, and D. H. COLLINS

1978 Catalogue of Type Invertebrate, Plant, and Trace Fossils in the Royal Ontario Museum. Life Sciences Miscellaneous Publications, Royal Ontario Museum. $151 \mathrm{pp}$.

WALCOTT, C. D.

1890 The fauna of the Lower Cambrian or Olenellus Zone. United States Geological Survey Annual Report 10:509-774.

WALTER, M. R., R. ELPHINSTONE, and G. R. HEYS

1989 Proterozoic and Early Cambrian trace fossils from the Amadeus and Georgina Basins, Central Australia. Alcheringa 13:209-256.

WEBBY, B. D.

1970 Late Precambrian trace fossils from New South Wales. Lethaia 3:79-109.

WETZEL, A., and R. G. BROMLEY

1996 Re-evaluation of the ichnogenus Helminthopsis-a new look at the type material. Palaeontology 39:1-19.

WINDER, C. G., and B. V. SANFORD

1972 Stratigraphy and Paleontology of the Palcozoic rocks of Southern Ontario. Guide Book, 1972 Geological Conference. A45-C45

YOUNG, F. G.

1972 Early Cambrian and older trace fossils from the southern Cordillera of Canada. Canadian Journal of Earth Sciences 9:1-17. 


\section{Appendix 1: Ichnotaxa from the Late Ordovician Georgian Bay Formation, Southern Ontario, with Corresponding ROM Repository Numbers}

\section{Ichnospecies}

Arenituba verso

Arenicolites isp.

Arthraria antiquata

Aulichnites parkerensis

Chondrites isp.

Cochlichnus anguineus

Cochlichnus n. isp.

Cruziana cf. lobosa

Cruziana problematica

Cruziana quadrata

Cruziana ispp.

Curvolithus multiplex

Didymaulichnus lyelli

Diplocraterion cf. biclavatum

Diplocraterion helmerseni

Diplocraterion parallelum

Fustiglyphus annulatus

Gordia marina

Gyrochorte comosa

Helminthopsis hieroglyphica

cf. Lingulichnus verticalis

Lockeia siliquaria

cf. Monocraterion tentaculatum

Monomorphichnus bilinearis

Monomorphichnus lineatus

cf. Palaeophycus crenulatus

Palaeophycus heberti

Palaeophycus striatus

Palaeophycus tubularis

Paleodictyon isp. a

?Paleodictyon isp. b

Phycodes flabellus

Phycodes palmatus

Planolites annularius

Planolites beverleyensis

Planolites constriannulatus

Rusophycus carbonarius

Protovirgularia dichotoma

?Protovirgularia isp.

Rusophycus cryptolithi

Rusophycus osgoodii

Rusophycus polonicus

Rusophycus pudicus

Skolithos magnus

Skolithos verticalis

Trichophycus lanosus

Trichophycus venosus

\section{ROM No.}

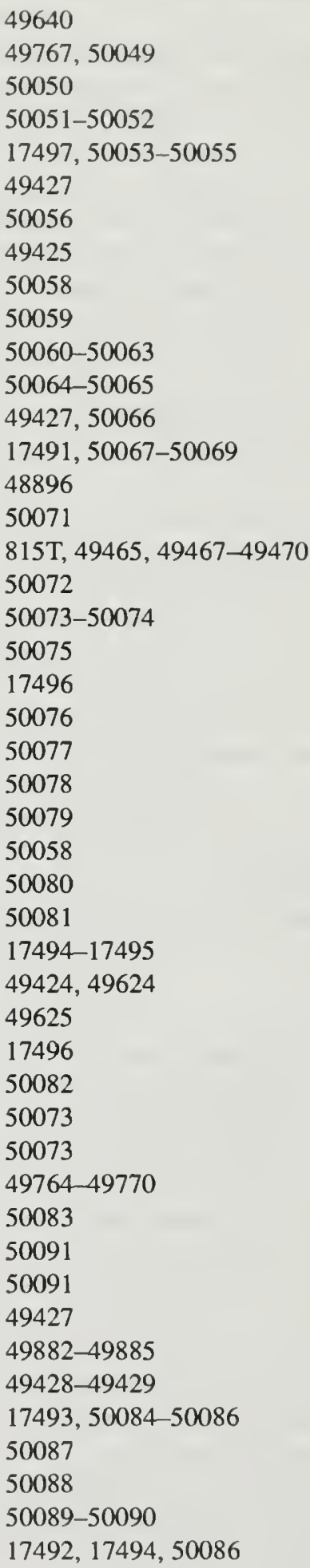




\section{Appendix 2: Locality Details-Toronto Region}

Locality numbers are those used during field studies. Localities 1-29 are on Manitoulin Island and did not contain particularly photogenic trace-fossil specimens.

\begin{tabular}{|c|c|c|}
\hline Locality No. & U.T.M. Co-ordinates & Description \\
\hline 30 & $620000 \mathrm{~m} \mathrm{Ex} 4837600 \mathrm{~m} \mathrm{~N}$ & Humber River at Eglinton Ave. \\
\hline 31 & $619500 \mathrm{~m} \mathrm{Ex} 4839100 \mathrm{~m} \mathrm{~N}$ & Humber River at Lawrence Ave. \\
\hline 32 & $620000 \mathrm{~m} \mathrm{Ex} 4835200 \mathrm{~m} \mathrm{~N}$ & Humber River north of Dundas St. \\
\hline 33 & $621750 \mathrm{~m} \mathrm{Ex} 4833800 \mathrm{~m} \mathrm{~N}$ & Humber River south of Dundas St. \\
\hline 34 & $619750 \mathrm{~m} \mathrm{Ex} 4833080 \mathrm{~m} \mathrm{~N}$ & Mimico Creek near intersection of Islington Ave. and Bloor St. \\
\hline 35 & $619750 \mathrm{~m} \mathrm{Ex} 4832900 \mathrm{~m} \mathrm{~N}$ & Mimico Creek at Springbrook Parkette \\
\hline 36 & $615700 \mathrm{~m} \mathrm{Ex} 4829150 \mathrm{~m} \mathrm{~N}$ & Etobicoke Creek south of The Queensway \\
\hline 37 & $615500 \mathrm{~m} \mathrm{Ex} 4829300 \mathrm{~m} \mathrm{~N}$ & Etobicoke Creek north of The Queensway \\
\hline 38 & $614400 \mathrm{~m} \mathrm{Ex} 4822200 \mathrm{~m} \mathrm{~N}$ & Credit River at Port Credit (J. C. Saddington Park) \\
\hline 39 & $608400 \mathrm{~m} \mathrm{Ex} 4821800 \mathrm{~m} \mathrm{~N}$ & Credit River south of Dundas St. \\
\hline 40 & $608250 \mathrm{~m} \mathrm{Ex} 4821900 \mathrm{~m} \mathrm{~N}$ & Credit River north of Dundas St. \\
\hline 41 & $608500 \mathrm{~m} \mathrm{Ex} 4822500 \mathrm{~m} \mathrm{~N}$ & Credit River north of Dundas St. \\
\hline 42 & $608400 \mathrm{~m} \mathrm{Ex} 4822600 \mathrm{~m} \mathrm{~N}$ & Credit River north of Dundas St. \\
\hline 43 & $607500 \mathrm{~m} \mathrm{Ex} 4823100 \mathrm{~m} \mathrm{~N}$ & Credit River north of Dundas St. \\
\hline 44 & $619000 \mathrm{~m} \mathrm{Ex} 4839500 \mathrm{~m} \mathrm{~N}$ & Humber River north of Lawrence Ave. \\
\hline 45 & $604450 \mathrm{~m} \mathrm{Ex} 4825750 \mathrm{~m} \mathrm{~N}$ & Credit River at Streetsville \\
\hline 46 & $608100 \mathrm{~m} \mathrm{Ex} 4832100 \mathrm{~m} \mathrm{~N}$ & Hwy. 410 extension south of Hwy. 401 \\
\hline 47 & $605450 \mathrm{~m} \mathrm{Ex} 4824850 \mathrm{~m} \mathrm{~N}$ & Credit River north of Eglinton Ave. \\
\hline 48 & $605500 \mathrm{~m} \mathrm{Ex} 4824750 \mathrm{~m} \mathrm{~N}$ & Credit River south of Eglinton Ave. \\
\hline 49 & $631600 \mathrm{~m} \mathrm{Ex} 4838200 \mathrm{~m} \mathrm{~N}$ & Don Valley Brick Yard (now filled) \\
\hline
\end{tabular}


Appendix 3: Comparison of Ichnotaxa Occurring within the Cincinnatian of Ohio, as Described by Osgood (1970), with Those Described Here from Coeval Strata of the Georgian Bay Formation, Southern Ontario

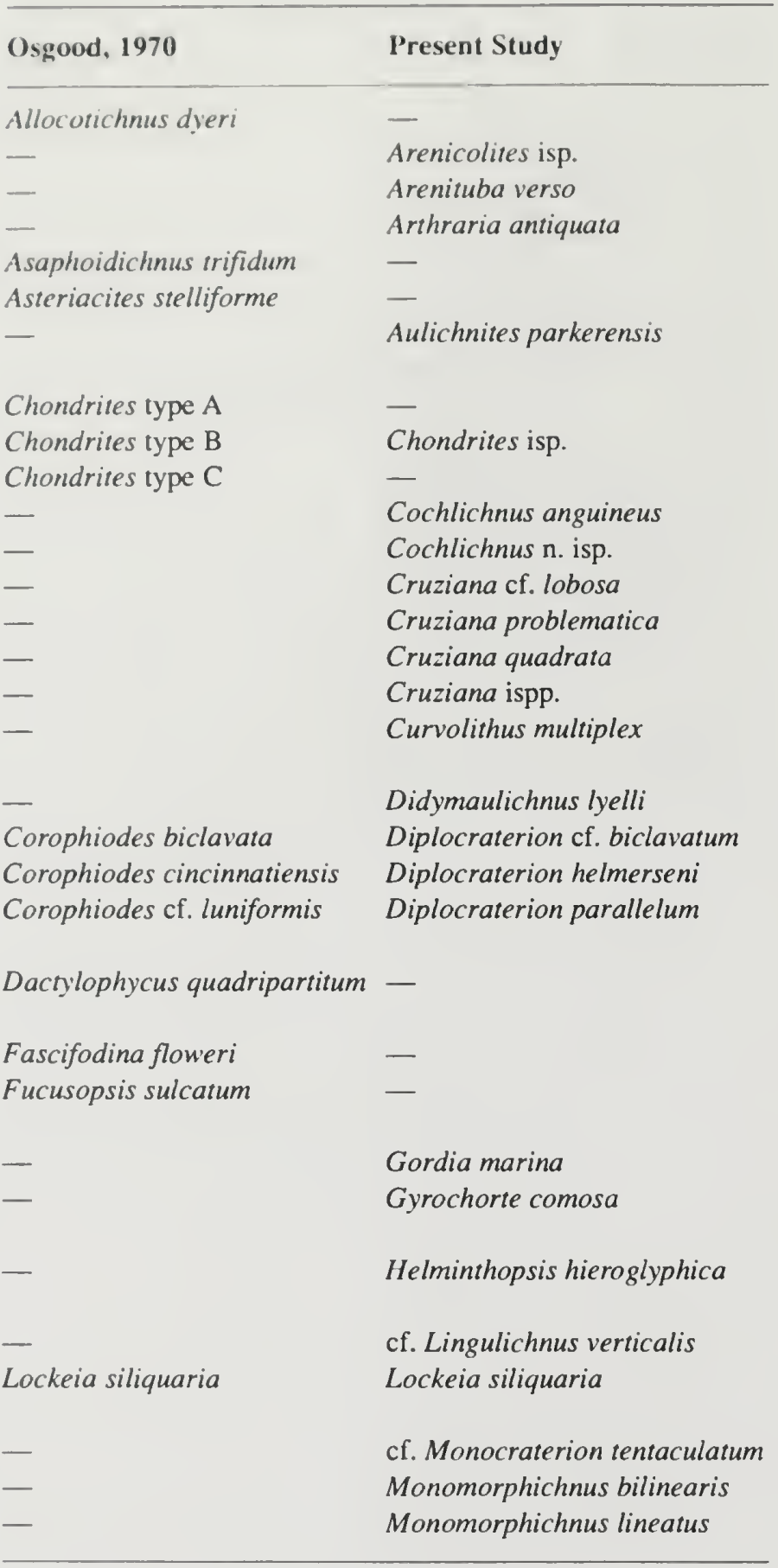

\begin{tabular}{|c|c|}
\hline Osgood, 1970 & Present Study \\
\hline Ormathichnus moniliformis & - \\
\hline Palaeophycus type A & cf. Palaeophycus crenulatus \\
\hline Palaeophycus type B & - \\
\hline - & Palaeophycus heberti \\
\hline - & Palaeophycus striatus \\
\hline Palaeophycus type C & Palaeophycus tubularis \\
\hline ?Paleodictyon sp. & Paleodictyon ispp. $\mathrm{a}-\mathrm{b}$ \\
\hline Petalichnus multipartitum & - \\
\hline Phycodes flabellum & Phycodes flabellus \\
\hline - & Phycodes palmatus \\
\hline - & Planolites annularius \\
\hline- & Planolites beverleyensis \\
\hline - & Planolites constriannulatus \\
\hline Rhabdoglyphus sp. (partim) & Fustiglyphus annulatus \\
\hline Rhabdoglyphus sp. & - \\
\hline - & Rusophycus carbonarius \\
\hline Rusophycus carleyi & - \\
\hline Rusophycus cryptolithi & Rusophycus cryptolithi \\
\hline - & Rusophycus osgoodii \\
\hline - & Rusophycus polonicus \\
\hline Rusophycus pudicum & Rusophycus pudicus \\
\hline - & Skolithos magnus \\
\hline ?Skolithos delicatulus & Skolithos verticalis \\
\hline Teratichnus confertum & - \\
\hline Trachomatichnus numerosum & - \\
\hline Trichophycus lanosum & Trichophycus lanosus \\
\hline Trichophycus venosum & Trichophycus venosus \\
\hline Tylichnus asperum & - \\
\hline Walcottia cookana & - \\
\hline Walcottia rugosa & Protovirgularia rugosa \\
\hline - & ?Protovirgularia isp. \\
\hline
\end{tabular}




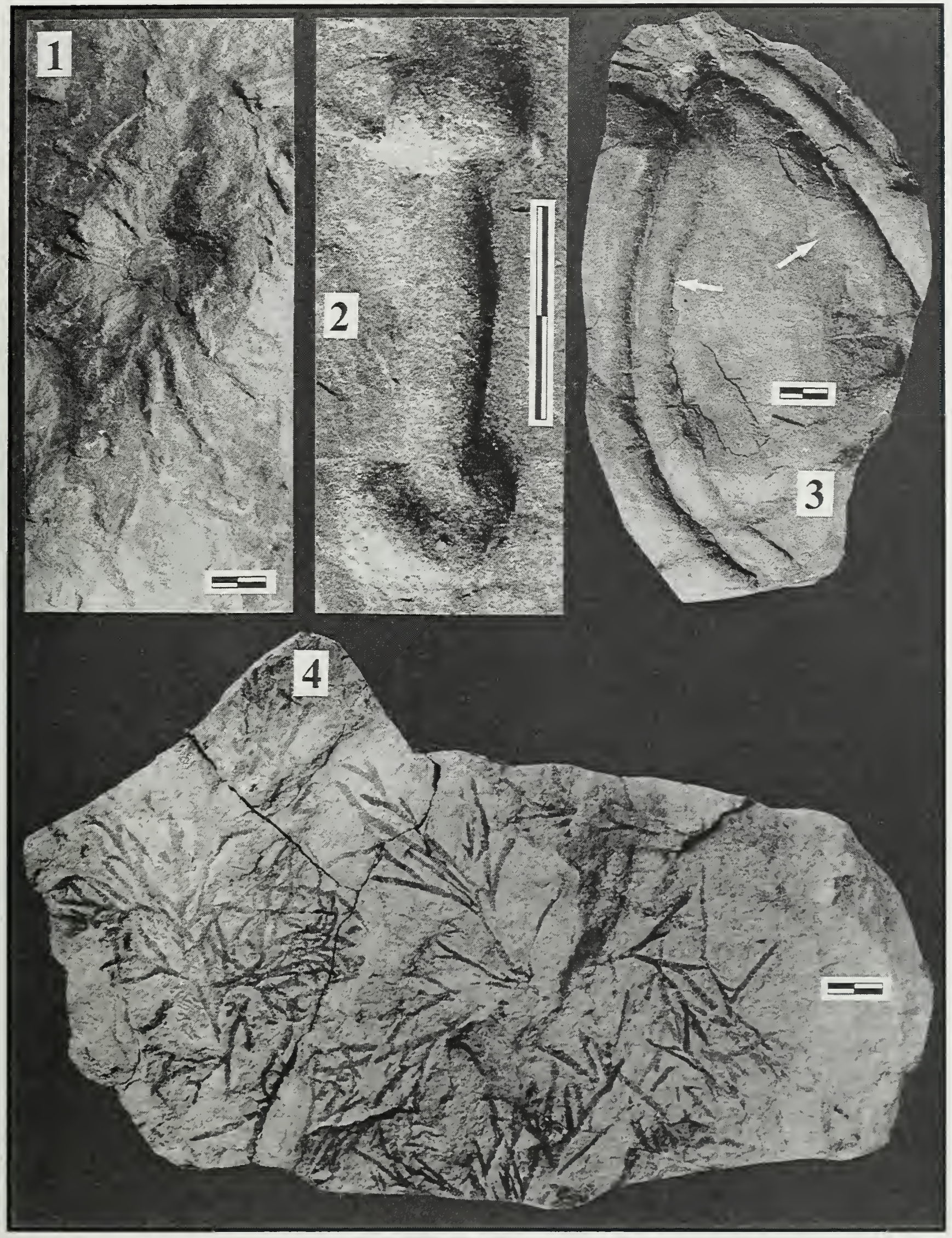

Plate 1, figs. $1-4$ (complete scale bars $=1 \mathrm{~cm})$.

1. Arenituba verso (Chamberlain), convex epirelief, ROM 49640.

2. Arthraria antiquata Billings, convex hyporelief, ROM 50050.

3. Aulichnites parkerensis Fenton and Fenton, convex epirelief, ROM 50052 (examples arrowed).

4. Chondrites isp., concave epirelief, ROM 50053. 


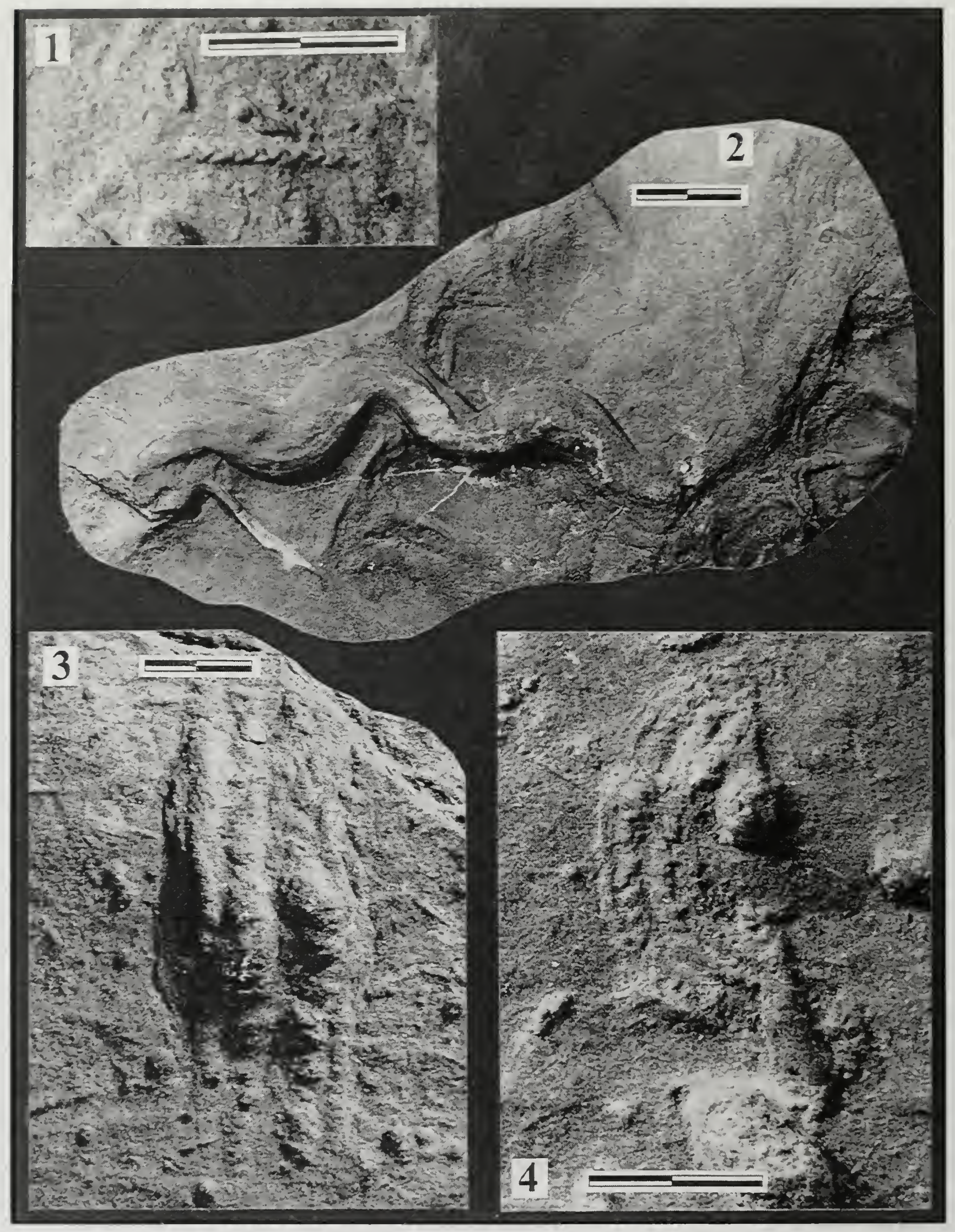

Plate 2, Figs. $1-4$ (complete scale bars $=1 \mathrm{~cm}$ ).

1. Cochlichnus anguineus Hitchcock, convex hyporelief, ROM 49427.

2. Cochlichnus n. isp., convex epirelief, ROM 50056.

3. Cruziana cf. lobosa Seilacher, convex hyporelief, ROM 49425.

4. Cruziana quadrata Seilacher, convex hyporelief, ROM 50059. 


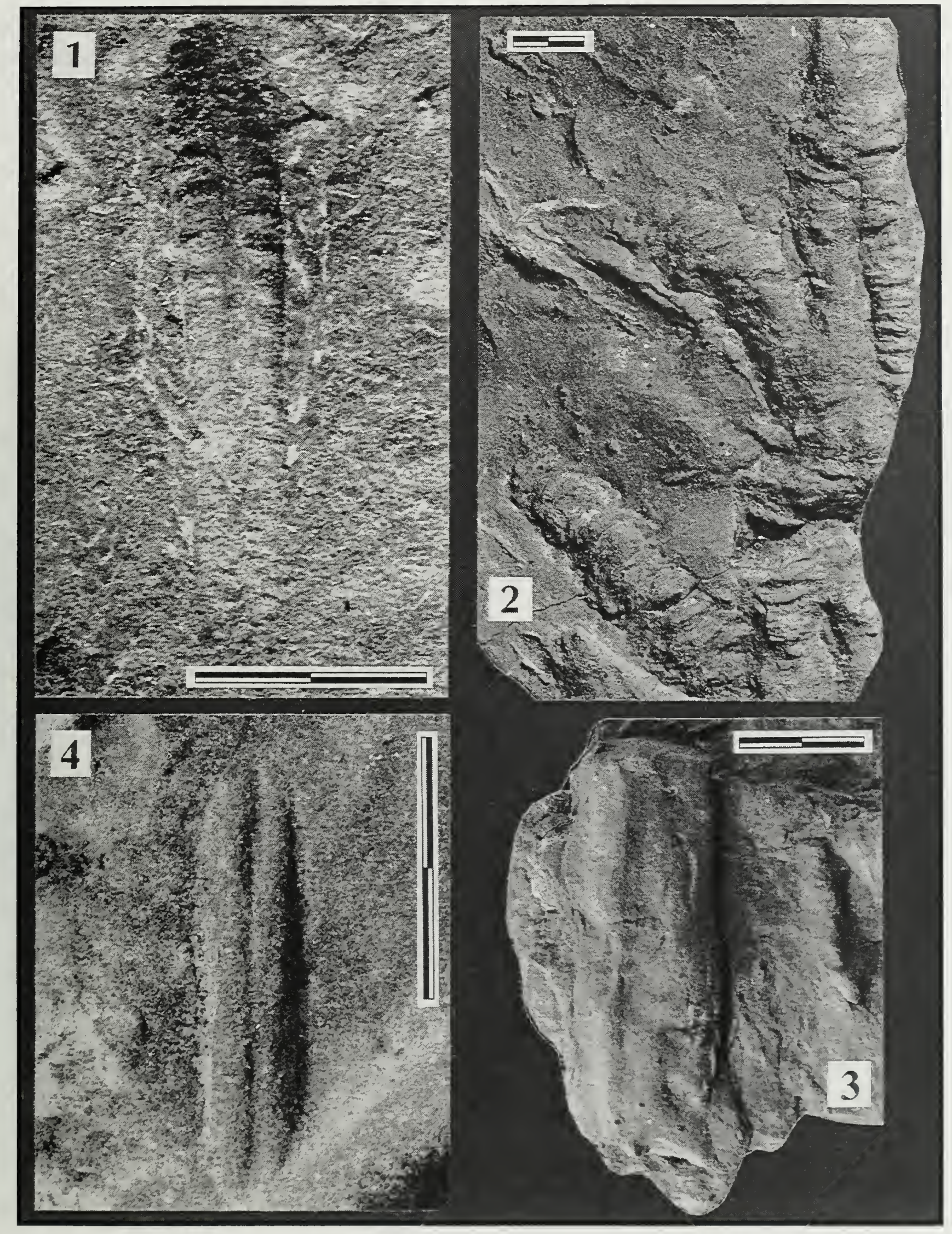

Plate 3, figs. $1-4$ (complete scale bars $=1 \mathrm{~cm}$ ).

1. Cruziana problematica (Schindewolf), convex hyporclief, ROM 50058.

2. Cruziana isp., convex hyporelicf, ROM 50062.

3. Curvolithus multiplex Fritsch, convex hyporclief, ROM 50064.

4. Didymaulichnus lyelli (Rouault), convex hyporelief, ROM 50066. 


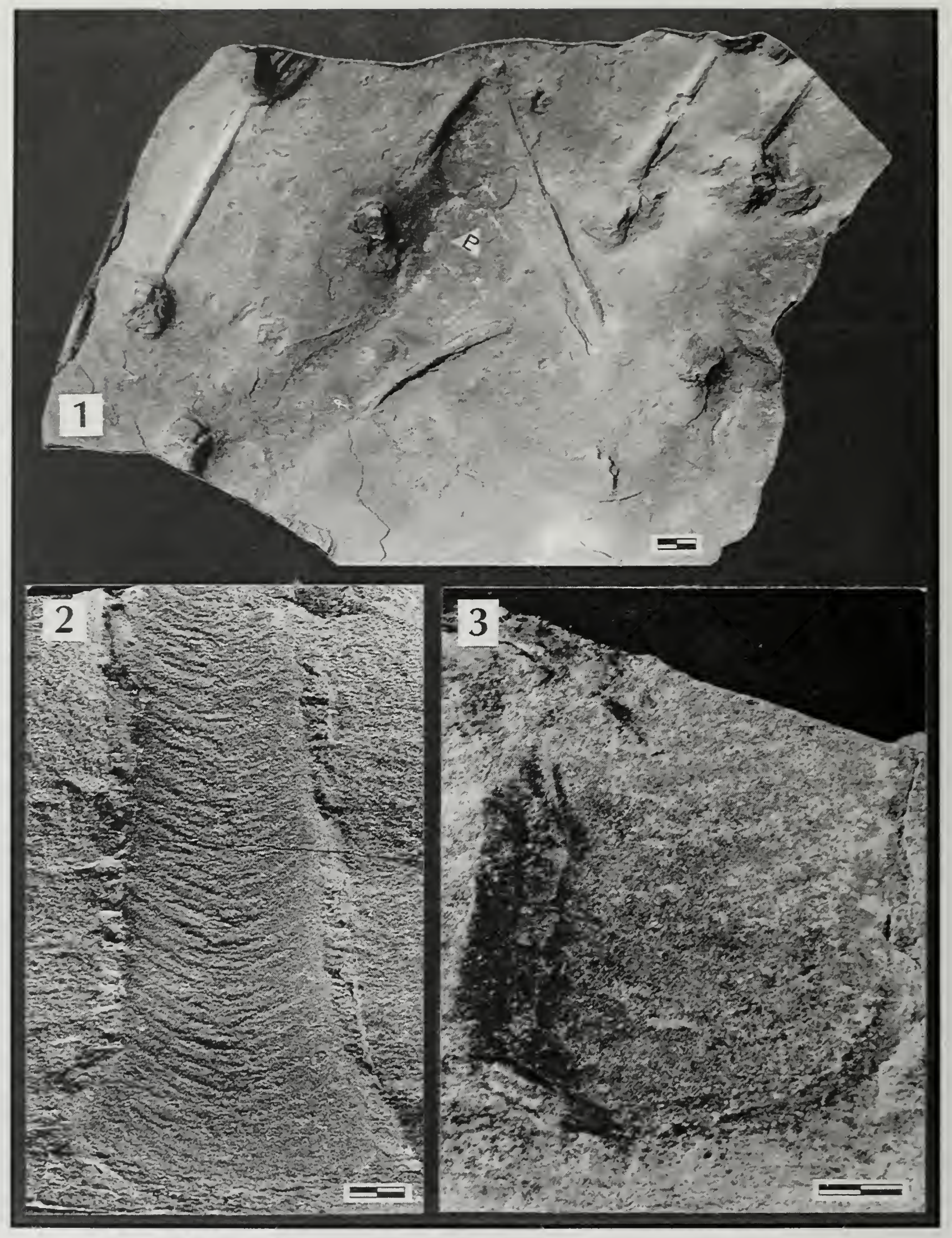

Plate 4, figs. 1-3 (complete scale bars $=1 \mathrm{~cm}$ ).

1. Diplocraterion cf. biclavatum (Miller), concave epirclief, ROM 17491.

2. Diplocraterion helmerseni (Öpik), convex endorelief, ROM 48896.

3. Diplocraterion parallelum Torell, convex endorelief, ROM 50071. 


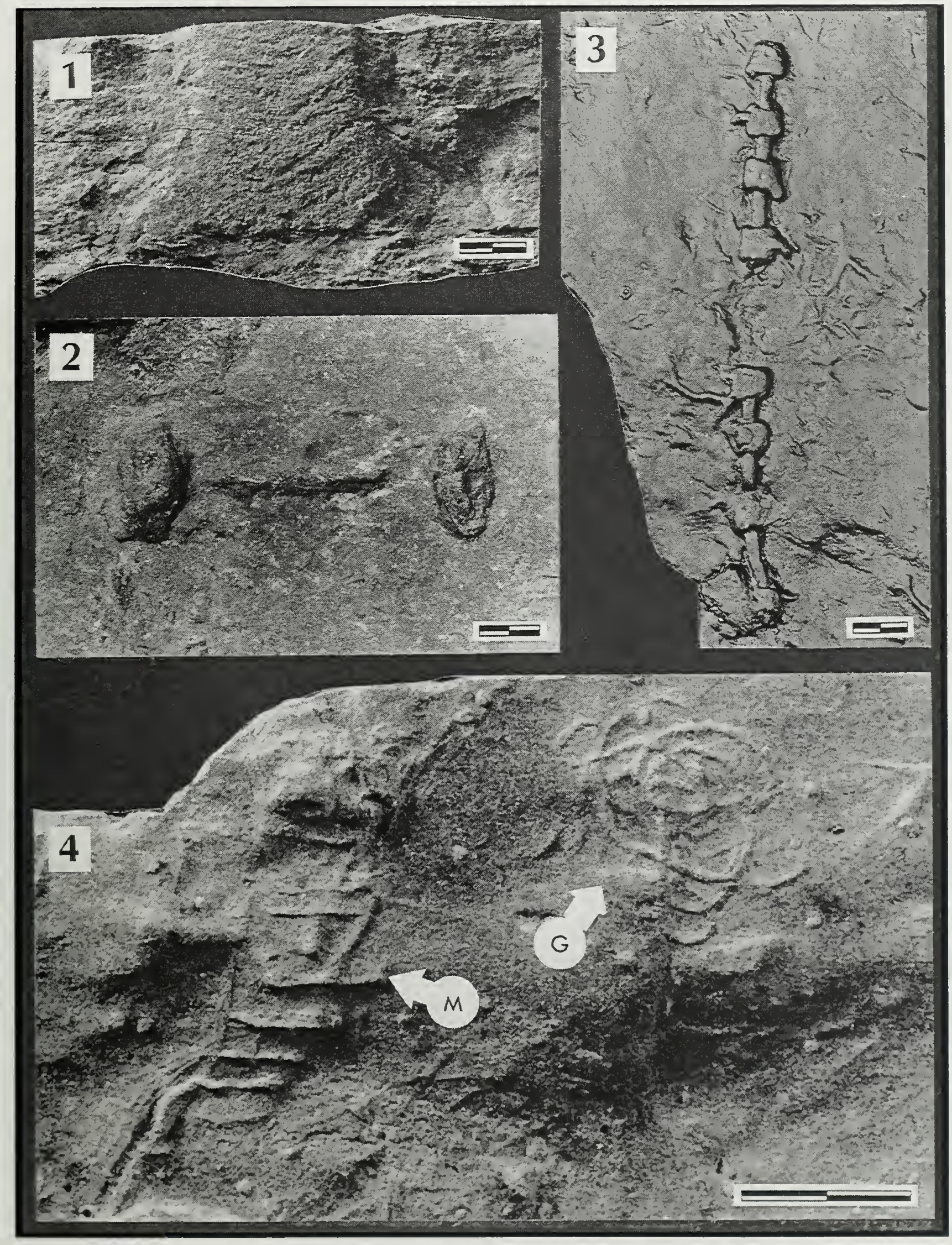

Plate 5, flgs. $1-4$ (complete scale bars $=1 \mathrm{~cm})$.

1. Diplocraterion biclavatum (Miller), convex endorelicf, ROM 50069.

2. Diplocraterion cf. biclavatum (Miller), concave cpirelief, ROM 50067.

3. Fustiglyphus annulatus Vialov, convex hyporelief, ROM 49465.

4. Gordia marina Emmons (G) and Monomorphichnus lineaus Crimes, Legg, Marcos and Arboleya (M), convex hyporelief, ROM 50072. 


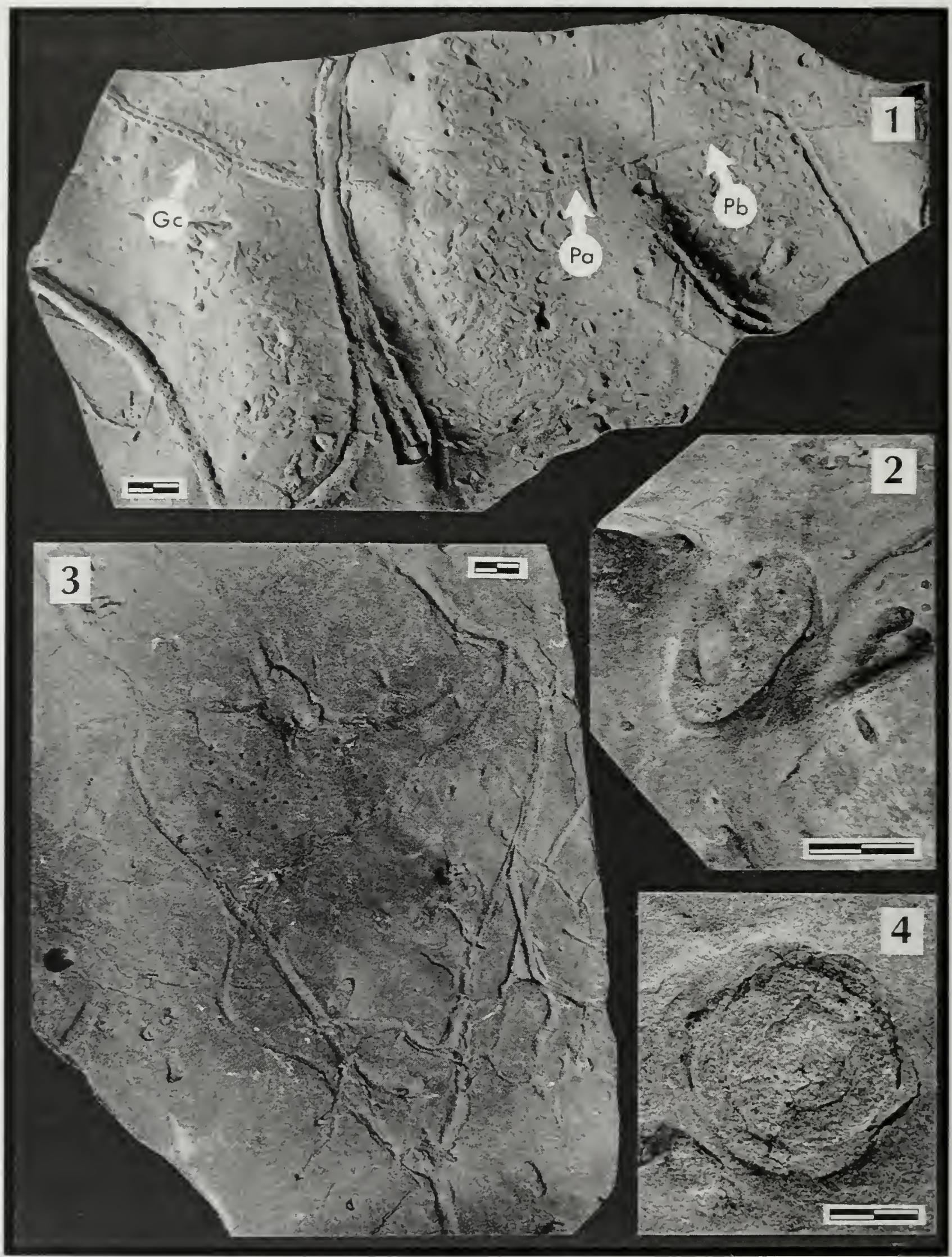

Plate 6, figs. $1-4$ (complete scale bars $=1 \mathrm{~cm}$ ).

1. Compound specimens of Gyrochorte comosa Heer (Gc), Planolites beverleyensis (Billings) (Pb), and Planolites annularius Walcott $(\mathrm{Pa})$, convex hyporelief, ROM 50073.

2. cf. Lingulichnus verticalis Hakes, convex hyporelief, ROM 17496.

3. Helminthopsis hieroglyphica Wetzel and Bromley, concave epirelief, ROM 50075.

4. cf. Monocraterion tentaculatum Torell, concave epirclief, ROM 50077. 


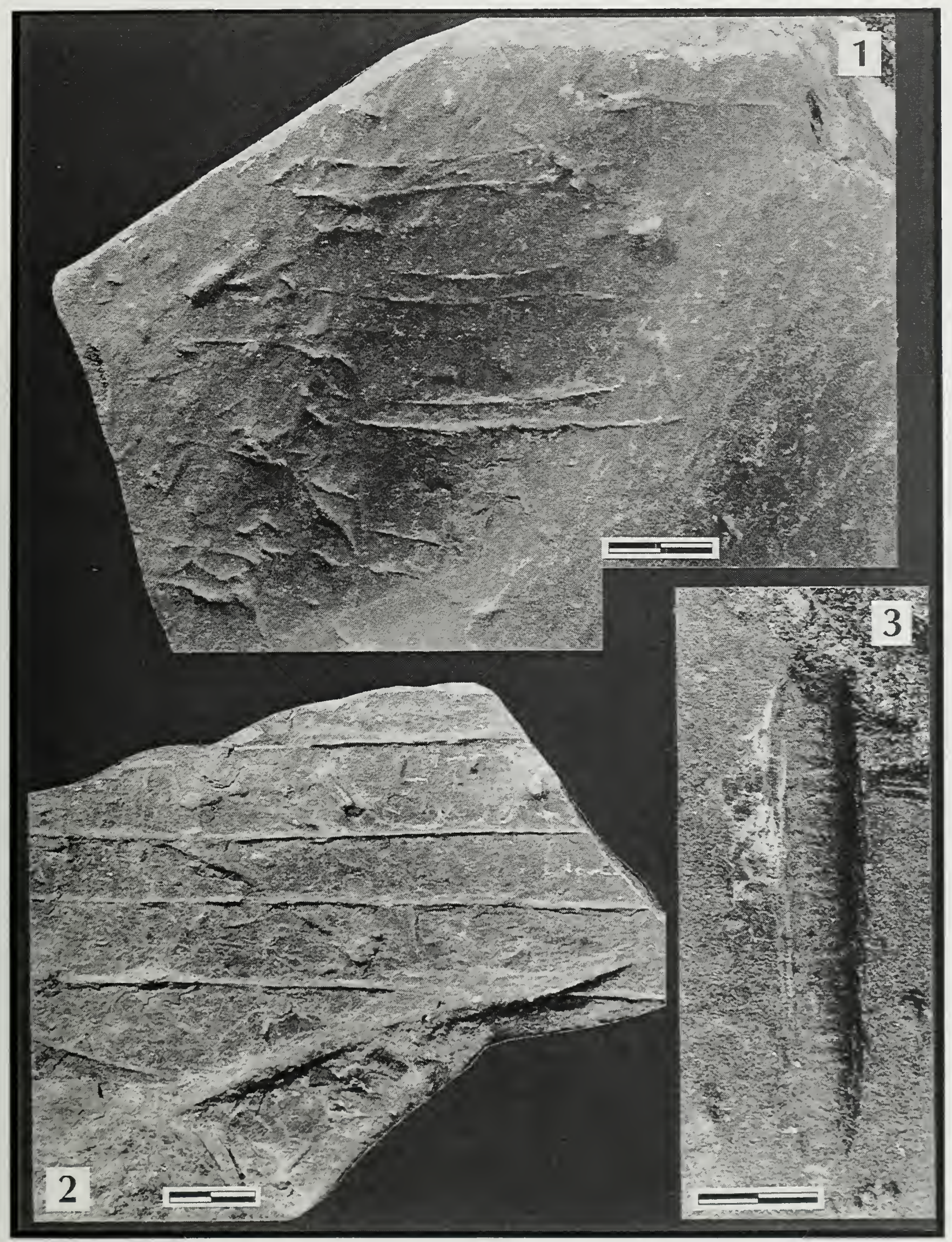

Plate 7, Figs. 1-3 (complete scalc bars = $1 \mathrm{~cm}$ ).

1. Monomorphichnus bilinearis Crimes, convex hyporelief, ROM 50078.

2. Monomorphichnus lineatus Crimes, Legg, Marcos and Arboleya, convex hyporclief, ROM 50079.

3. cf. Palaeophycus crenulatus Buckman, convex hyporelief, ROM 50058 


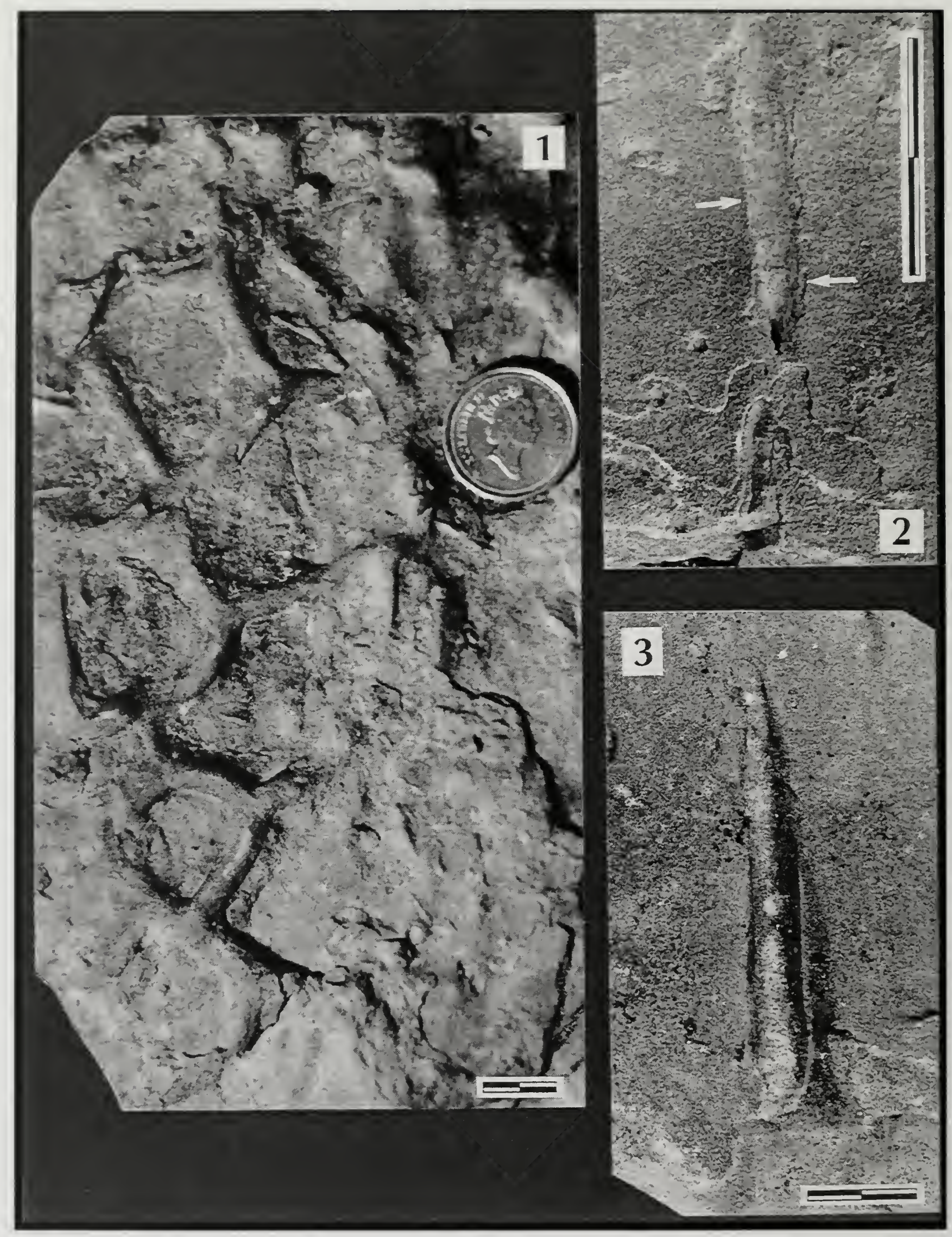

Plate 8, Figs. $1-3$ (complete scale bars $=1 \mathrm{~cm}$ ).

1. Paleodictyon isp. a, convex hyporelief, ROM 49424.

2. Palaeophycus heberti (de Saporta), convex hyporelief, ROM 50080. Note pronounced linings (arrowed).

3. Palaeophycus tubularis Hall, convex hyporelief, ROM 17494. 


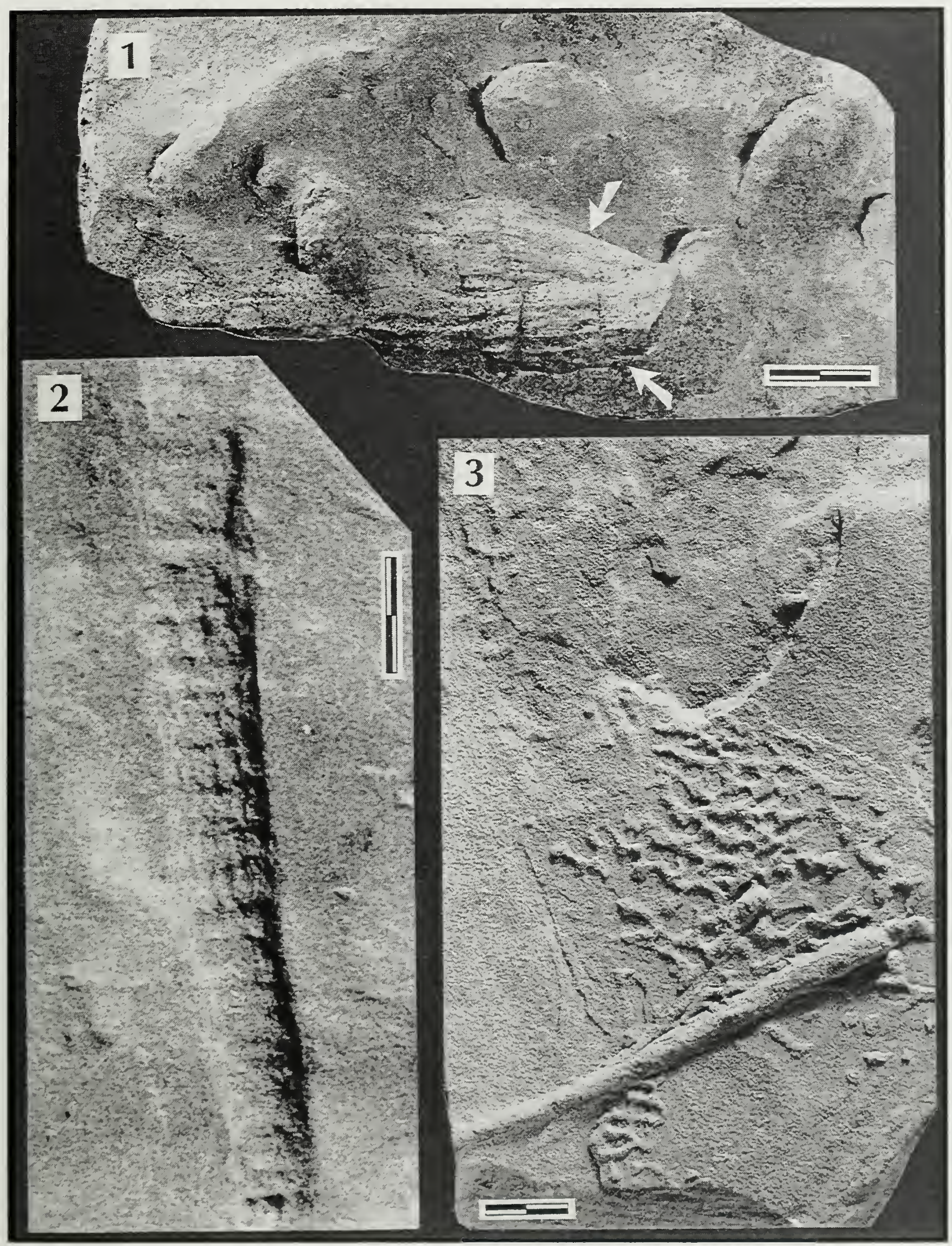

Plate 9, figs. 1-3 (complete scale bars $=1 \mathrm{~cm}$ )

1. Two intersecting (arrowed) Palaeophycus striatus Hall, convex hyporelief, ROM 50081.

2. Planolites constriannulatus Stanley and Pickerill, convex hyporelief, ROM 49764.

3. ?Paleodictyon isp. b, convex hyporelief, ROM 49625. 


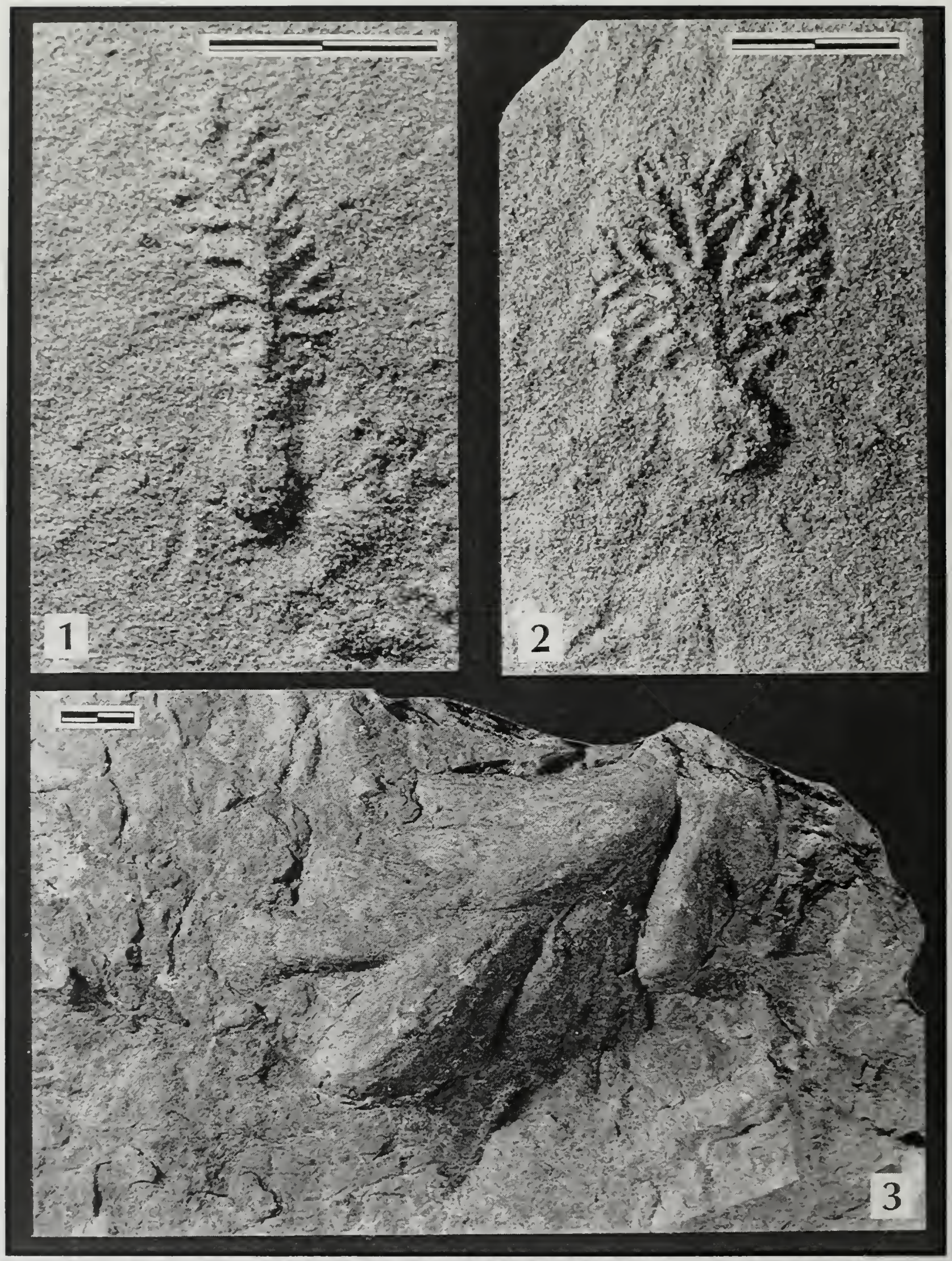

Plate 10, figs. $1-3$ (complete scale bars $=1 \mathrm{~cm}$ ).

1. Protovirgularia rugosa Miller and Dyer, convex hyporelief, ROM 50091.

2. ?Protovirgularia isp., convex hyporelief, ROM 50091.

3. Phycodes palmatus (Hall), convex hyporelief, ROM 50082. 


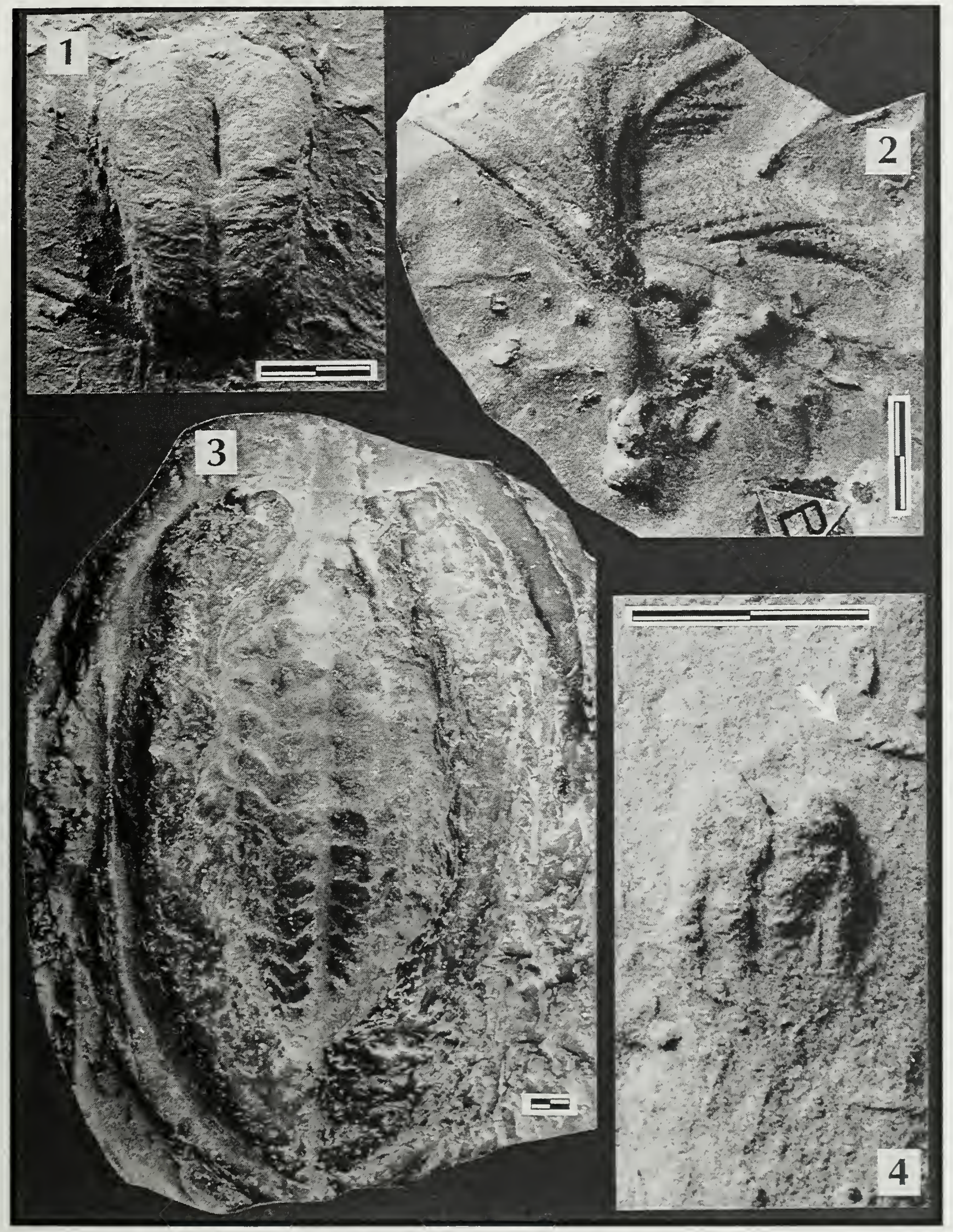

Plate 11, Figs. $1-4$ (complete scale bars $=1 \mathrm{~cm}$ ).

1. Rusophycus pudicus Hall, convex hyporelief, ROM 50085.

2. Phycodes flabellus (Miller and Dyer), convex hyporelief, ROM 17496

3. Rusophycus polonicus Orlowski, Radwański and Ronicwicz, convex hyporelicf, ROM 49429

4. Rusophycus cryptolithi Osgood, convex hyporelief, ROM 49427. Arrow indicates Cochlichnus anguineus Hitchcock as illustrated in Pl. 2, fig. 1. 


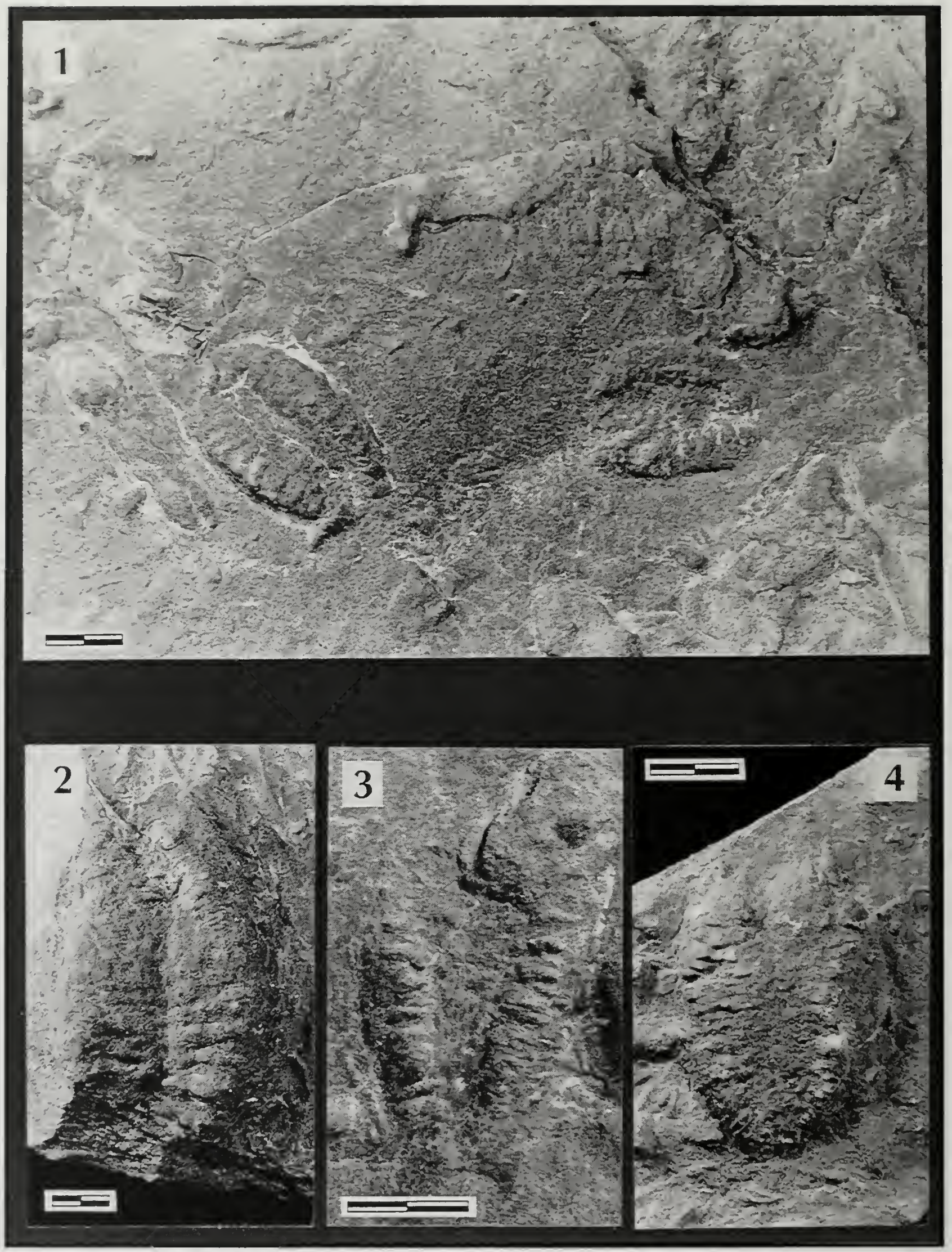

Plate 12, Figs. $1-4$ (complete scale bars $=1 \mathrm{~cm}$ ).

Rusophycus osgoodii n. isp.

1. Paratypes, convex hyporelief, ROM 49883

2. Paratype, convex hyporelief, ROM 49885.

3. Holotype, convex hyporelief, ROM 49882.

4. Paratype, convex hyporclief, ROM 49884. 


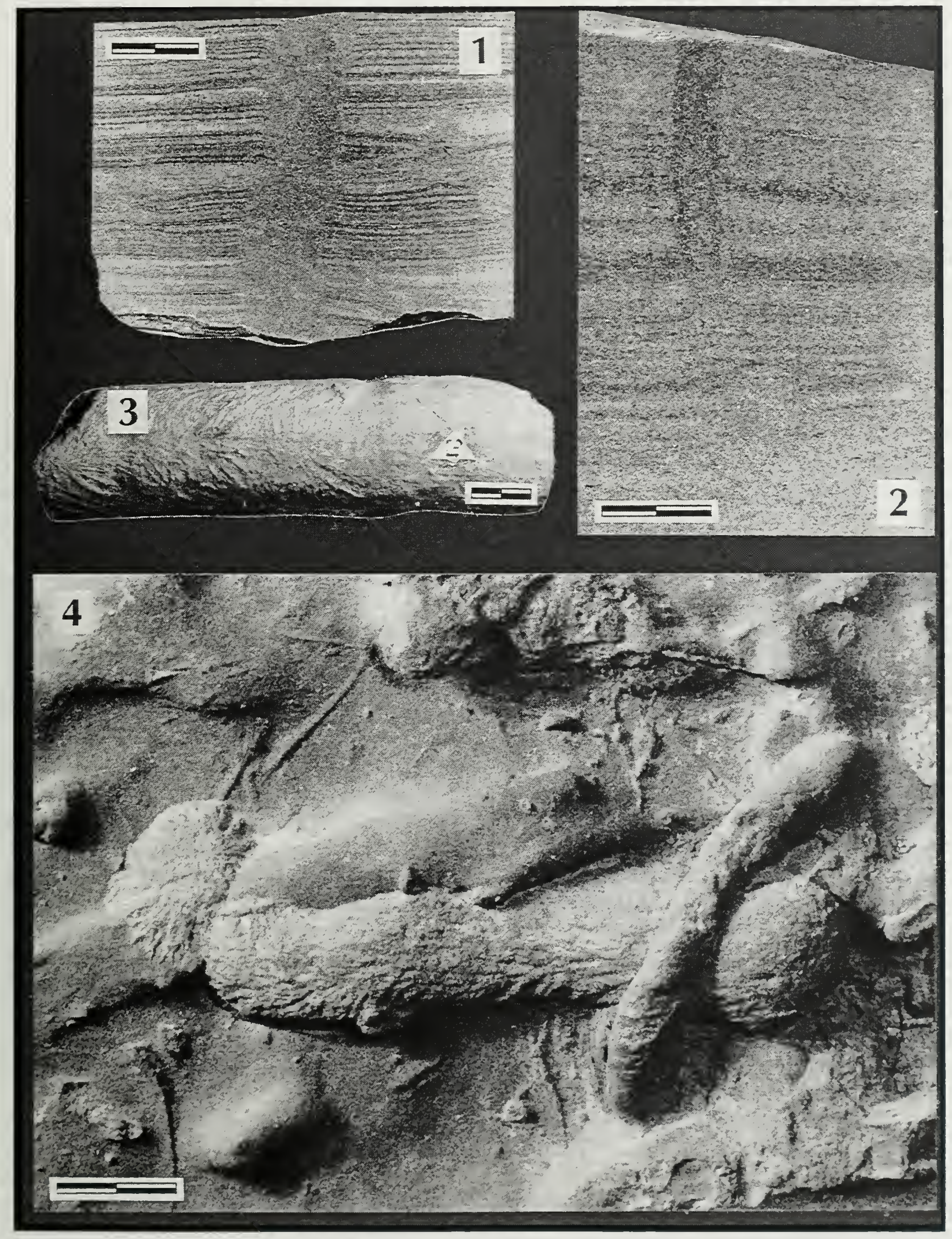

Plate 13, figs. $1-4$ (complete scale bars $=1 \mathrm{~cm}$ ).

1. Skolithos magnus Howell, endorelief, ROM 50087.

2. Skolithos verticalis (Hall), endorelief, ROM 50088.

3. Trichophycus venosus Miller, full relief, ROM 17492.

4. Trichophycus lanosus Miller and Dyer, convex hyporelief, ROM 50089. 


\section{ROYAL ONTARIO MUSEUM LIFE SCIENCES PUBLICATIONS INSTRUCTIONS TO AUTHORS}

Authors should prepare their manuscripts carefully according to the following instructions; failure to do so will result in the manuscript's being returned to the author for revision. All manuscripts are considered on the understanding that they are not currently offered for publication elsewhere.

1. General Papers for publication are accepted from ROM staff members and research associates, and from researchers reporting on work done with ROM collections. Monographs on the flora and/or fauna of Ontario by authors not affiliated with the ROM may be considered for publication. Financial contributions towards publication may be required. Authors are expected to write clearly and concisely and to omit any material not essential for an understanding of the main theme of the paper.

2. Format Manuscripts (including captions, synonymies, literature cited, and tables) should be provided in WordPerfect (for DOS) 5.1/5.2, doublespaced, with corresponding hard copy, to the head of Publications. The submission should include a separate sheet giving the names and affiliations of the author(s), the title of the publication, the series if applicable, the number of typed pages, the number of tables, and the number of plates and figures. Manuscripts should normally be organized in the following order: contents, abstract, introduction, materials and methods, results, discussion, conclusions, summary (if manuscript is long), acknowledgements, appendices, and literature cited. Authors are encouraged to include foreign-language translations of the summary, if appropriate. Main headings should be centred; subheadings should be left-justified to the text margin. The first line of the first paragraph in each new section should not be indented. A single space only should be left between sentences. Material intended to be typeset as italic must be provided as italic, not as underlined roman type. Literature citations in the text should be in one of the following forms: "Jones (1994)" or "(Jones, 1994)" or "(Smith, 1990:71-79, fig. 17)."

3. Standard Sources The primary authority on questions of format and style is the Guide to Authors and Editors, available from ROM Publications. For mat- ters not covered in the guide, consult the CBE Style Manual. Other standard sources are as follows: for English spelling, The Concise Oxford Dictionary; for Canadian place names and coordinates, Canada Gazetteer Atlas; for the spelling of geographic names, The Times Atlas of the World.

4. Abstract All papers must be preceded by a short, factual abstract, about one per cent of the text in length. The abstract may be followed by four to six key words in parentheses.

5. Taxonomy The name of a taxon should be given in full in headings, at the beginnings of paragraphs, and at its first occurrence in the text. Give the authority and date, if appropriate, with the first mention of each taxon, but not thereafter. Taxonomic papers, particularly synonymies, should follow the layout in the Guide to Authors and Editors.

6. Literature Cited A complete list of references, in alphabetical order of authors, must be given at the end of the paper. When two or more works of one author are cited, they should be listed chronologically. The names of journals should not be abbreviated. For correct bibliographic form, see the Guide to Authors and Editors.

7. Tables All tables should be typed on separate sheets and numbered consecutively in arabic numerals in the order of their first mention in the text. Mark the location of each table in the margin of the text.

8. Plates, Figures, and Text-figures Illustrations may be designated according to the conventions of the author's discipline; in some disciplines grouped photographs of scientific subject matter are commonly termed Plates, while line drawings and locality and other illustrations that occupy a full page or less are Text-figures. Usage must be consistent throughout the paper. A full-page illustration with its caption should be sized to fit an area of $17.3 \times 22.75 \mathrm{~cm}\left(6.8^{\prime \prime} \times 9^{\prime \prime}\right)$ for a Contribution; for Occasional Papers, the area is $14.1 \times 21.2 \mathrm{~cm}\left(5.5^{\prime \prime} \times 8.3^{\prime \prime}\right)$. If captions are lengthy, they may be placed on the facing page. A scale or magnification factor should be included. Authors are reminded that when illustrations are reduced, magnification factors will change, and that they are responsible for the conversion. For details, see the Guide to Authors and Editors. 
( 


\section{ROYAL ONTARIO MUSEUM LIFE SCIENCES CONTRIBUTIONS}

1.ife Sciences Contmbutions are a numbered series of scientific publications of varied subject natter. Most recent contributions include the following:

161 Shallow-Water Hydroids of Bermuda: (Superlamily Plumularioidea)

Dule R. Culder

1997, 92 pp.. ill., $\$ 19.95$

ISBN ()-8885+-421-9

160 Analysis of Morphological and Behavioural Evidence for the Phylogeny and Higher Classification of Trichoptera (Insecti) Hemry E. Frania and Glem B. Wiggins 1997, 72 pp., ill., \$19.95

ISBN ()-88854-420-0

159 Revision, Phylogeny, and Discussion of Biology and Biogeography of the Fish Genus Plesiops (Perciformes: Plesiopidae)

Randall D. Mooi

1995, 112 pp., ill., $\$ 24.95$

ISBN 0-88854-414-6

158 Breeding-Bird Populations in Jack Pine and Mixed Jack Pine/Deciduous Stands in Central Ontario

Ross D. James and Mark K. Peck

1995, 40 pp., ill., \$14.95

ISBN 0-88854-413-8

157 Classification and Evolution of the Oraseminae in the Old World, Including Revisions of Two Closely Related Genera of Eucharitinae (Hymenoptera: Eucharitidae)

John Michael Heraty

1994, 184 pp., ill., \$24.95

ISBN 0-88854-412-X

156 Conodonts of the Lower Border Group and Equivalent Strata (Lower Carboniferous) in Northern Cumbria and the Scottish Borders, U.K. Mark A. Purnell

1992, 80 pp., ill., \$19.95

ISBN 0-88854-405-7

155 Revision of the World Species of Spalangiopelta (Hymenoptera: Chalcidoidea: Pteromalidae: Ceinae) D. Christopher Darling 1991, 48 pp., ill., \$11.00 ISBN 0-88854-395-6

154 Shallow-Water Hydroids of Bermuda: The Thecatae, Exclusive of Plumularioidea Dale R. Calder

1991, 144 pp., ill., $\$ 24.50$ ISI3N 0-88854-354-9
153 Silurian Trilobites from the Northern Yukon Territory

Rolf Ludvigsen and Ronald P. Tripp 1990, 64 pp., ill., \$12.95

ISIBN ()-88854-349-2

I52 The Type Species of the Ordovician Trilobite Genus Isotelus: I. gigas Dekay, 1824

David M. Rudkin and Ronald P. Tripp 1989, 24 pp., ill., $\$ 10.25$

ISBN 0-88854-345-X

151 The Structure of the Call Note System of the WarblingVireo

Daryl How'es-Jones and Jon C. Barlow' 1988, 40 pp., ill., $\$ 11.00$

ISBN 0-88854-343-3

150 Late Cretaceous-Early Tertiary

Dinoflagellates and Acritarchs from the Kashi Area, Tarim Basin, Xinjiang Province, China Mao Shaozhi and Geoffrey Norris 1988,100 pp., ill., $\$ 25.00$

ISBN 0-88854-334-4

149 Occurrence of the Cladid Inadunate Crinoid Thalamocrinus in the Silurian (Wenlockian) of New York and Ontario

George C. Mclntosh and Carlton E. Brett 1988, 20 pp., ill., \$7.75

ISBN 0-88854-342-5

148 Shallow-Water Hydroids of Bermuda:

The Athecatae

Dale R. Calder

1988, 112 pp., ill., $\$ 24.50$

ISBN 0-88854-339-5

147 Biostratigraphy and Palaeontology of the Scollard Formation, Late Cretaceous and Paleocene of Alberta

Loris S. Russell

1987, 23 pp., ill., $\$ 7.00$

ISBN 0-88854-338-7

\section{A catalogue of ROM publications in print is available from}

University of Toronto Press

10 St. Mary Strect, Suite 700

Toronto, Ontario M4Y 2W8

Canada

Tel. (416) 978-2239

Fax (416) 978-4738 